Prepared in cooperation with the U.S. Department of the Army Environmental and Natural Resources Management Office of the U. S. Army Signal Center and Fort Gordon

\title{
Assessment of Groundwater, Soil-Gas, and Soil Contamination at the Vietnam Armor Training Facility, Fort Gordon, Georgia, 2009-2011
}

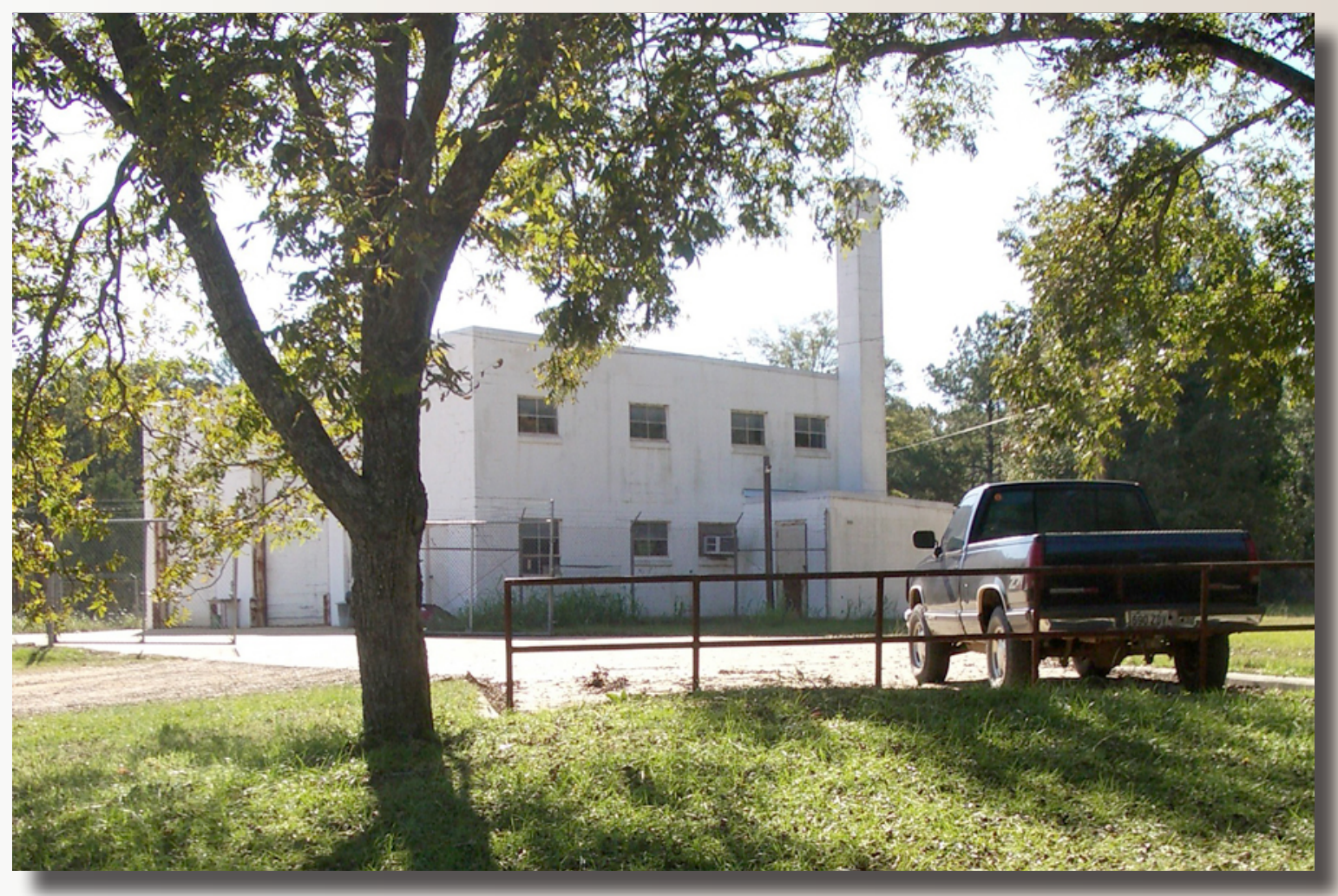

Open-File Report 2012-1160 
Cover. Building on the Vietnam Armor Training Facility property. Photograph by W. Fred Falls, U.S. Geological Survey. 


\section{Assessment of Groundwater, Soil-Gas, and Soil Contamination at the Vietnam Armor Training Facility, Fort Gordon, Georgia, 2009-2011}

By Wladmir B. Guimaraes, W. Fred Falls, Andral W. Caldwell, W. Hagan Ratliff, John B. Wellborn, and James E. Landmeyer

Prepared in cooperation with the U.S. Department of the Army Environmental and Natural Resources Management Office of the U.S. Army Signal Center and Fort Gordon

Open-File Report 2012-1160 


\section{U.S. Department of the Interior \\ KEN SALAZAR, Secretary \\ U.S. Geological Survey \\ Marcia K. McNutt, Director}

\section{U.S. Geological Survey, Reston, Virginia: 2012}

For more information on the USGS - the Federal source for science about the Earth, its natural and living resources, natural hazards, and the environment, visit http://www.usgs.gov or call 1-888-ASK-USGS

For an overview of USGS information products, including maps, imagery, and publications, visit http://www.usgs.gov/pubprod

To order this and other USGS information products, visit http://store.usgs.gov

Any use of trade, product, or firm names is for descriptive purposes only and does not imply endorsement by the U.S. Government.

Although this report is in the public domain, permission must be secured from the individual copyright owners to reproduce any copyrighted materials contained within this report.

Suggested citation:

Guimaraes, W.B., Falls, W.F., Caldwell, A.W., Ratliff, W.H., Wellborn, J.B., and Landmeyer, J.E., 2012, Assessment of groundwater, soil-gas, and soil contamination at the Vietnam Armor Training Facility, Fort Gordon, Georgia, 2009-2011 (revised from OFR 2011-1200): U.S. Gelogical Survey Open-File Report 2012-1160, 56 p. 


\section{Contents}

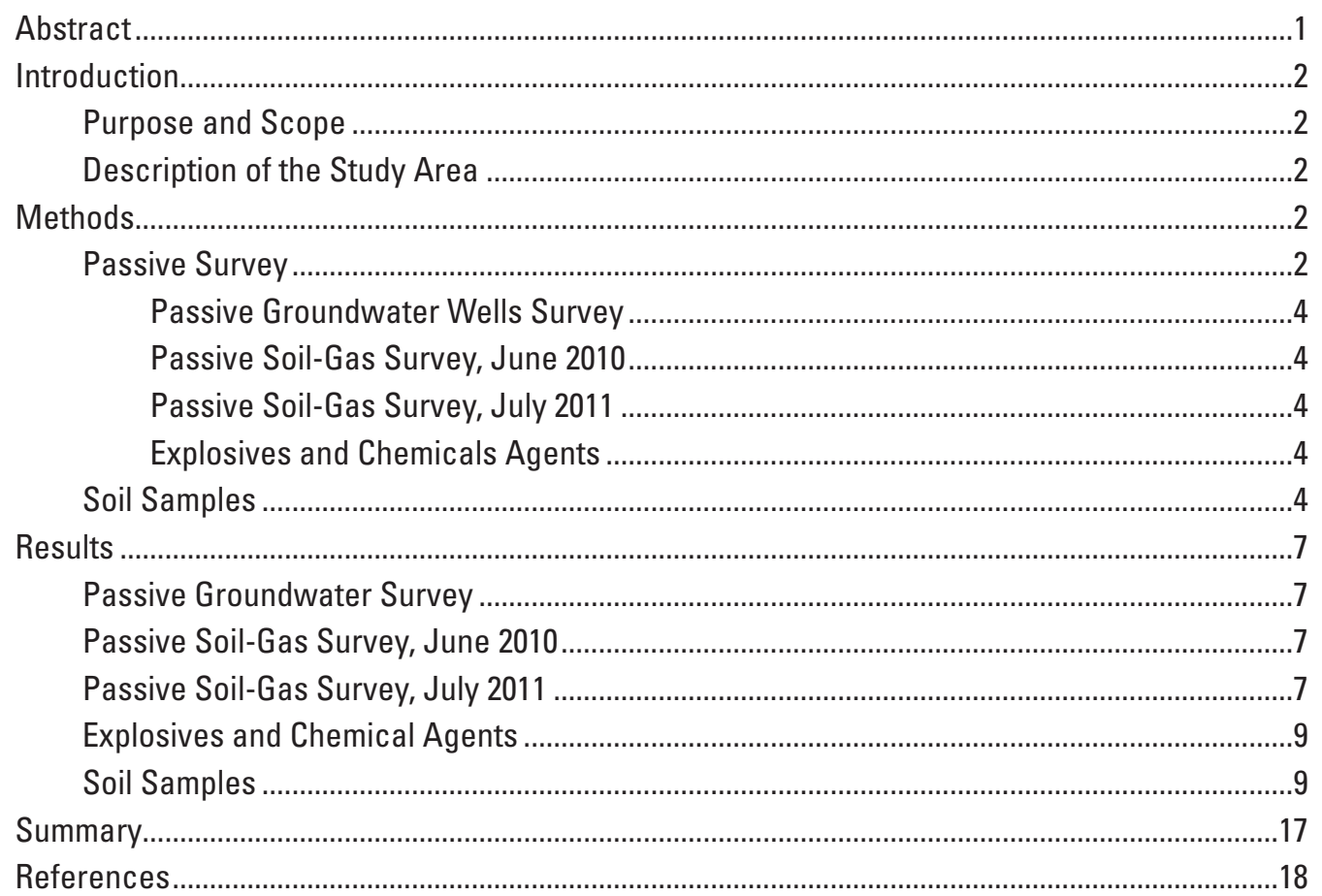

\section{Figures}

1. Map showing location of Vietnam Armor Training Facility, Fort Gordon, Georgia

2. Photographs showing soil-gas sampler prior to being installed in a shallow borehole and following retrieval from a borehole and prior to shipping to the laboratory for analysis.

3-12. Maps showing:

3. Locations of groundwater and soil-gas sampling sites, Vietnam Armor Training Facility, Fort Gordon, Georgia, 2009-2011...

4. Locations of explosives and chemical agents and soil sampling sites, Vietnam Armor Training Facility, Fort Gordon, Georgia, 2009-2010...

5. Total petroleum hydrocarbons concentrations in passive groundwater samplers, Vietnam Armor Training Facility, Fort Gordon, Georgia, 2009-2010 .................8

6. Benzene concentrations in passive groundwater samplers, Vietnam Armor Training Facility, Fort Gordon, Georgia, February 2010.

7. Octane concentrations in passive groundwater samplers, Vietnam Armor Training Facility, Fort Gordon, Georgia, February 2010.

8. Combined concentrations of undecane, tridecane, and pentadecane in passive groundwater samplers, Vietnam Armor Training Facility, Fort Gordon, Georgia, February 2010 


\section{Figures-Continued}

9. Total petroleum hydrocarbons mass in soil-gas samplers, Vietnam Armor

Training Facility, Fort Gordon, Georgia, June 2010 ...

10. Combined masses of benzene, toluene, ethylbenzene, and total xylene in soil-gas samplers, Vietnam Armor Training Facility, Fort Gordon, Georgia, June 2010

11. Total petroleum hydrocarbons mass in soil-gas samplers, Vietnam Armor Training Facility, Fort Gordon, Georgia, July 2011

12. Combined masses of benzene, toluene, ethylbenzene, and total xylene in soil-gas samplers, Vietnam Armor Training Facility, Fort Gordon, Georgia, July 2011.

\section{Tables}

Tables located at the back of the report

1. Concentrations of organic compounds detected in passive groundwater samplers collected from the Vietnam Armor Training Facility, Fort Gordon, Georgia, 2009-2010

2. Mass of organic compounds detected in soil-gas samplers collected from the Vietnam Armor Training Facility, Fort Gordon, Georgia, June 2010

3: Mass of organic compounds detected in soil-gas samplers, Vietnam Armor Training Facility, Fort Gordon, Georgia, July 2011

4. Mass of explosives and chemical agents detected in soil-gas samplers collected from the Vietnam Area Training Facility, Fort Gordon, Georgia, 2009-2010

5. Inorganic compounds detected in the soil from land surface to 6 inches below land surface, site 1, Vietnam Armor Training Facility, Fort Gordon, Georgia, August 30, 2010

6. Inorganic compounds detected in the soil from land surface to 6 inches below land surface, site 2, Vietnam Armor Training Facility, Fort Gordon, Georgia, August 30, 2010

7. Inorganic compounds detected in the soil from land surface to 6 inches below land surface, site 3, Vietnam Armor Training Facility, Fort Gordon, Georgia, August 30, 2010

8. Inorganic compounds detected in the soil from land surface to 6 inches below land surface, site 4, Vietnam Armor Training Facility, Fort Gordon, Georgia, August 30, 2010

9. Inorganic compounds detected in the soil from land surface to 6 inches below land surface, site 5, Vietnam Armor Training Facility, Fort Gordon, Georgia, August 30, 2010 


\section{Conversion Factors}

Inch/Pound to SI

\begin{tabular}{|c|c|c|}
\hline Multiply & By & To obtain \\
\hline \multicolumn{3}{|c|}{ Length } \\
\hline inch (in.) & 2.54 & centimeter $(\mathrm{cm})$ \\
\hline inch (in.) & 25.4 & millimeter $(\mathrm{mm})$ \\
\hline foot $(\mathrm{ft})$ & 0.3048 & meter $(\mathrm{m})$ \\
\hline mile (mi) & 1.609 & kilometer (km) \\
\hline gallon (gal) & 3.785 & liter (L) \\
\hline
\end{tabular}

Horizontal coordinate information is referenced to the North American Datum of 1983 (NAD 83).

\section{Acronyms and abbreviations}

$\begin{array}{ll}\text { BTEX } & \text { benzene, toluene, ethylbenzene, and xylene (total) } \\ \text { VTAF } & \text { Vietnam Armor Training Facility } \\ \mathrm{mg} / \mathrm{kg} & \text { milligrams per kilogram } \\ \mathrm{mL} & \text { milliliter } \\ \mu \mathrm{g} & \text { microgram } \\ \mu \mathrm{g} / \mathrm{L} & \text { microgram per liter } \\ \text { MDL } & \text { method detection level } \\ \text { MTBE } & \text { methyl tert-butyl ether } \\ \text { PAH } & \text { polycyclic aromatic hydrocarbon } \\ \text { PCE } & \text { perchloroethylene (also known as tetrachloroethylene) } \\ \text { RCRA } & \text { Resource Conservation and Recovery Act } \\ \text { RSL } & \text { regional screening level } \\ \text { SVOC } & \text { semivolatile organic compound } \\ \text { TCE } & \text { trichloroethylene } \\ \text { TPH } & \text { total petroleum hydrocarbon } \\ \text { USEPA } & \text { U.S. Environmental Protection Agency } \\ \text { USGS } & \text { U.S. Geological Survey } \\ \text { VOC } & \text { volatile organic compound }\end{array}$




\title{
Assessment of Groundwater, Soil-Gas, and Soil Contamination at the Vietnam Armor Training Facility, Fort Gordon, Georgia, 2009-2011
}

\author{
By Wladmir B. Guimaraes, ${ }^{1}$ W. Fred Falls, ${ }^{1}$ Andral W. Caldwell, ${ }^{1}$ W. Hagan Ratliff, ${ }^{2}$ John B. Wellborn, ${ }^{3}$ and \\ James E. Landmeyer ${ }^{1}$
}

\section{Abstract}

The U.S. Geological Survey, in cooperation with the U.S. Department of the Army Environmental and Natural Resources Management Office of the U.S. Army Signal Center and Fort Gordon, Georgia, assessed the groundwater, soil gas, and soil for contaminants at the Vietnam Armor Training Facility (VATF) at Fort Gordon, from October 2009 to September 2011. The assessment included the detection of organic compounds in the groundwater and soil gas, and inorganic compounds in the soil. In addition, organic contaminant assessment included organic compounds classified as explosives and chemical agents in selected areas. The assessment was conducted to provide environmental contamination data to the U.S. Army at Fort Gordon pursuant to requirements of the Resource Conservation and Recovery Act Part B Hazardous Waste Permit process. This report is a revision of "Assessment of soil-gas, surface-water, and soil contamination at the Vietnam Armor Training Facility, Fort Gordon, Georgia, 2009-2010," Open-File Report 2011-1200, and supersedes that report to include results of additional samples collected in July 2011.

Four passive samplers were deployed in groundwater wells at the VATF in Fort Gordon. Total petroleum hydrocarbons and benzene and octane were detected above the method detection level at all four wells. The only other volatile organic compounds detected above their method detection level were undecane and pentadecane, which were detected in two of the four wells. Soil-gas samplers were deployed at 72 locations in a grid pattern across the VATF on June 3, 2010, and then later retrieved on June 9, 2010. Total petroleum hydrocarbons were detected in 71 of the 72 samplers (one sampler was destroyed in the field and not analyzed) at levels above the method detection level, and the combined mass of benzene, toluene, ethylbenzene, and total xylene (BTEX) was detected

\footnotetext{
${ }^{1}$ U.S. Geological Survey, Columbia, South Carolina.

${ }^{2}$ Environmental Branch, Fort Gordon, Georgia.

${ }^{3}$ Environmental and Natural Resources, Fort Gordon, Georgia.
}

above the detection level in 31 of the 71 samplers that were analyzed. Other volatile organic compounds detected above their respective method detection levels were naphthalene, 2-methyl-naphthalene, tridecane, 1,2,4-trimethylbenzene, and perchloroethylene.

After the results of the 71 soil-gas samplers were received, 31 additional passive soil-gas samplers were deployed on July 14, 2011, and retrieved on July 18, 2011. These 31 samplers were deployed on a larger areal scale to better define the extent of the contamination. Total petroleum hydrocarbons were detected above their method detection level at all 31 samplers, whereas BTEX was detected above its method detection level at 17 of the 31 samplers. Other organic compounds detected above their method detection levels were naphthalene, 2-methyl-naphthalene, octane, undecane, tridecane, pentadecane, 1,2,4-trimethylbenzene, 1,3,5-trimethylbenzene, chloroform, and perchloroethylene.

Subsequent to the 2010 soil-gas survey, four areas determined to have elevated contaminant mass were selected and sampled for explosives and chemical agents. No detections of explosives or chemical agents above their respective method detection levels were found at any of the sampling locations. The same four locations that were sampled for explosives and chemical agents were selected for the collection of soil samples. A fifth location also was selected on the basis of the elevated contaminant mass of the soil-gas survey. No metals that exceeded the Regional Screening Levels for Industrial Soils, as classified by the U.S. Environmental Protection Agency, were detected at any of the five VATF locations. The soil samples also were compared to values from the ambient, uncontaminated (background) levels for soils in South Carolina, as classified by the South Carolina Department of Health and Environmental Control. Because South Carolina is adjacent to Georgia and the soils in the Coastal Plain are similar, these comparisons are valid. No similar values are available for Georgia to use for comparison purposes. The metals that were detected above the ambient background levels for South Carolina, as classified by the South Carolina Department of Health and Environmental Control, include aluminum, arsenic, barium, beryllium, calcium, chromium, copper, iron, lead, magnesium, manganese, nickel, potassium, sodium, and zinc. 


\section{Introduction}

This report is a revision of and supersedes U.S. Geological Survey Open-File Report 2011-1200, "Assessment of soilgas, surface-water, and soil contamination at the Vietnam Armor Training Facility, Fort Gordon, Georgia, 2009-2010" to include results of additional samples taken in July 2011. Fort Gordon is a U.S. Department of the Army facility located in east-central Georgia, approximately 10 miles (mi) southwest of Augusta, Georgia (fig. 1). A cantonment (military housing) area is located at the northwestern boundary of Fort Gordon. The Vietnam Armor Training Facility (VATF) is located in a relatively flat, open area in the south-central part of Fort Gordon adjacent to McDuffie Road, near the intersection with Forestry Road. Little historical information is available about the VATF except that armor training was conducted at the site (Hagan Ratliff, Applied Services and Informational Systems, Inc., Installation Restoration Program Manager, oral commun., November 6, 2009). Currently (2012), the VATF site is used by the Fort Gordon Fish and Wildlife Program of the Environmental Division of the Fort Gordon Directorate of Public Works. The site includes several buildings, a parking area, and a wash rack, with built-in drains, where vehicles are washed. An initial investigation to study the possible contamination of the soil and groundwater at the VATF is warranted, because no historical information is available about the activities and use of the site during the Vietnam War era. The site is located in the outcrop area for the Cretaceous-age aquifer system, which is used for drinking water farther downgradient (Williams, 2007). Groundwater from the VATF site may discharge to streams in the area, enabling potential contaminants to be transported off the Fort Gordon property.

\section{Purpose and Scope}

The purpose of this report is to provide the results of the analyses of samples collected by the U.S. Geological Survey, in cooperation with the U.S. Department of the Army Environmental and Natural Resources Management Office of the U.S. Army Signal Center and Fort Gordon, to assess the groundwater, soil gas, and soil for contaminants at the VATF at Fort Gordon, Georgia, from October 2009 to July 2011. The assessment was conducted to provide environmental contamination data to the U.S. Army at Fort Gordon. The assessment included passive samplers deployed in ground-water wells and in the soil in a grid pattern over the generalized extent of the VATF to determine the presence of organic contaminants, explosives, and chemical agents from the VATF. The presence of inorganic compounds was determined from soil samples. The report presents the analytical results for a total of 116 sites.

\section{Description of the Study Area}

Fort Gordon is an Army facility located in east-central Georgia, approximately $10 \mathrm{mi}$ southwest of Augusta, Georgia (fig. 1). Fort Gordon lies in the northern part of the Coastal
Plain Physiographic Province and south of the Fall Line. Surficial soil and sediments are characterized by unconsolidated sands, indurated sands and semiconsolidated sandstones, and layers of clay that include kaolinite (Gregory and others, 2001).

\section{Methods}

All samples were collected in February, June, and September 2010, and July 2011, and were analyzed by using standard laboratory practices (U.S. Geological Survey, variously dated). The methods were selected to provide data to determine the presence or absence of contamination in the groundwater, soil gas, and soil at the VATF. The soil-gas method that was used provides results that are qualitative, and the groundwater and soil samples provide quantitative data.

\section{Passive Survey}

The passive survey was conducted by using the GORE ${ }^{\mathrm{TM}}$ Module (module), a commercially available passive diffusion sampler based on GORE-TEX ${ }^{\circledR}$ membrane technology (U.S. Environmental Protection Agency, 1998; W.L. Gore and Associates, Inc., 2004; American Society for Testing and Materials, 2006). The module consisted of an adsorbent material placed inside a shoestring-shaped GORE-TEX ${ }^{\circledR}$ tube (fig. 2A). The adsorbent material can adsorb a wide variety of volatile organic compounds (VOC), including solvents such as perchloroethylene (PCE; also known as tetrachloroethylene); trichloroethylene (TCE); benzene, toluene, ethylbenzene, and xylenes (collectively referred to as BTEX); methyl tert-butyl ether (MTBE); semivolatile organic compounds (SVOC); total petroleum hydrocarbons (TPH); and polycyclic aromatic hydrocarbons (PAH), such as naphthalene.

The modules were deployed into the area of interest and then removed after a specified time period. For the groundwater wells survey, the modules were inserted into water. For the soil-gas survey and the explosives and chemical agents, the modules were tied to a string, attached to a cork plug to prevent the entrance of surface water and ambient surface sources of contamination, inserted into a shallow borehole, and later removed. Modules that were deployed in water were removed after 1 to 4 hours, whereas modules deployed in the soil were removed after 5 to 10 days. After the modules were removed, they were placed in their original 20-milliliter (mL) gas-tight vial (fig. $2 B$ ) and sent to a commercial laboratory (W.L. Gore and Associates, Inc.) for analysis by gas chromatography/mass spectrometry using a modification of U.S. Environmental Protection Agency (USEPA) method $8260 / 8270$ to include thermal desorption of the sample. The laboratory is in compliance with Good Laboratory Practices and ISO Guide 25 (International Organization for Standardization, 1990). 


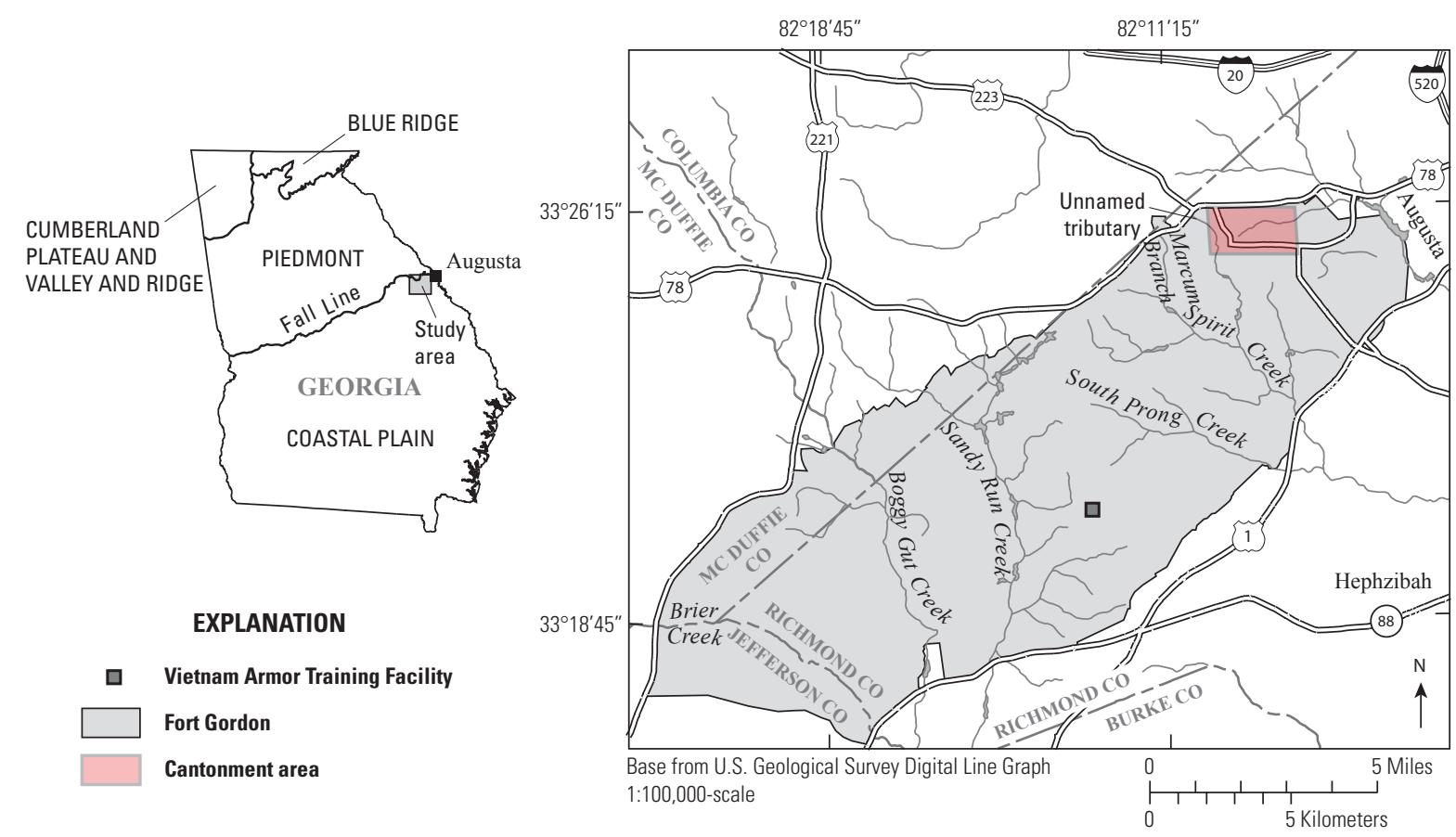

$82^{\circ} 13^{\prime}$

82¹2'50"

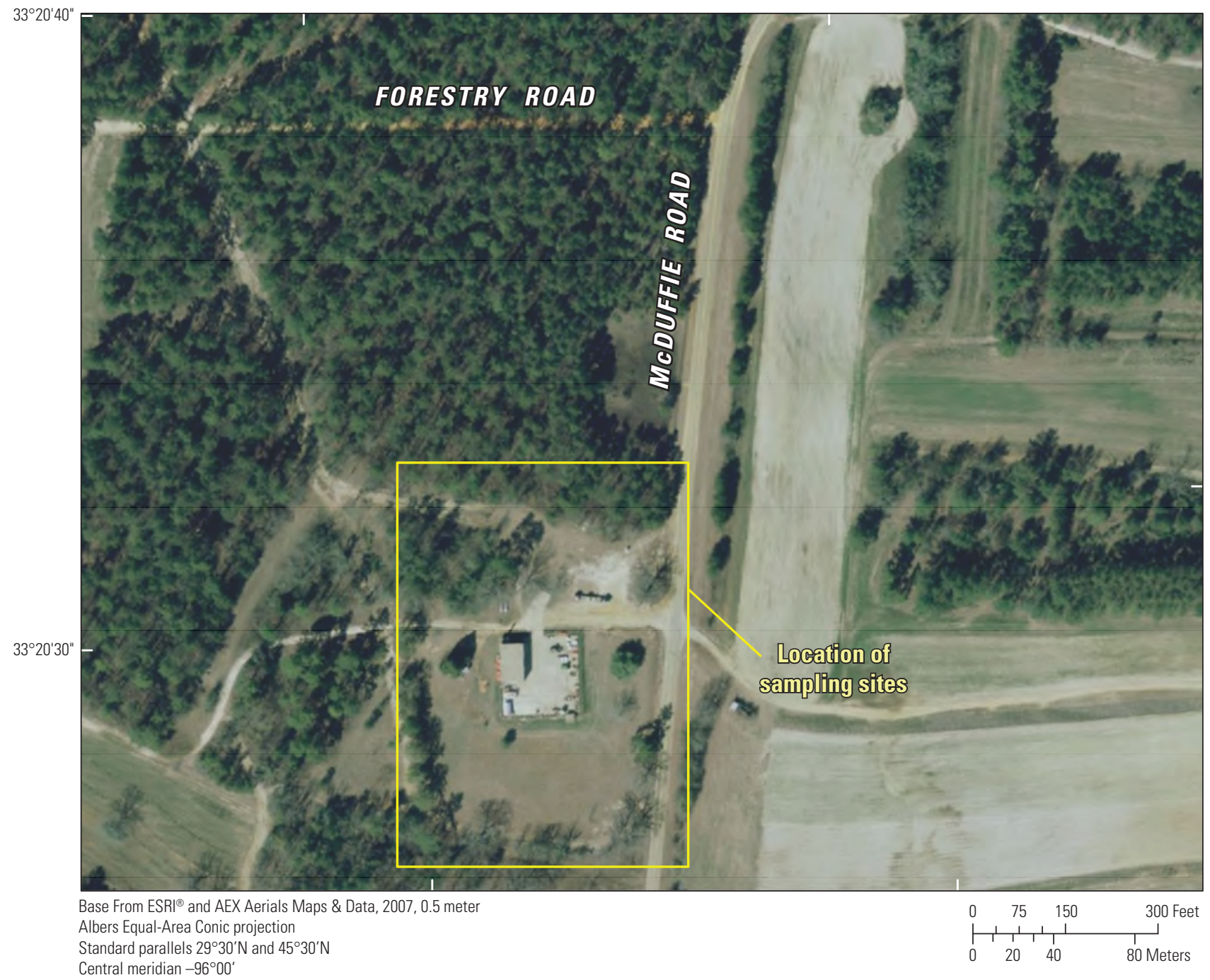

Figure 1. Location of Vietnam Armor Training Facility, Fort Gordon, Georgia. 

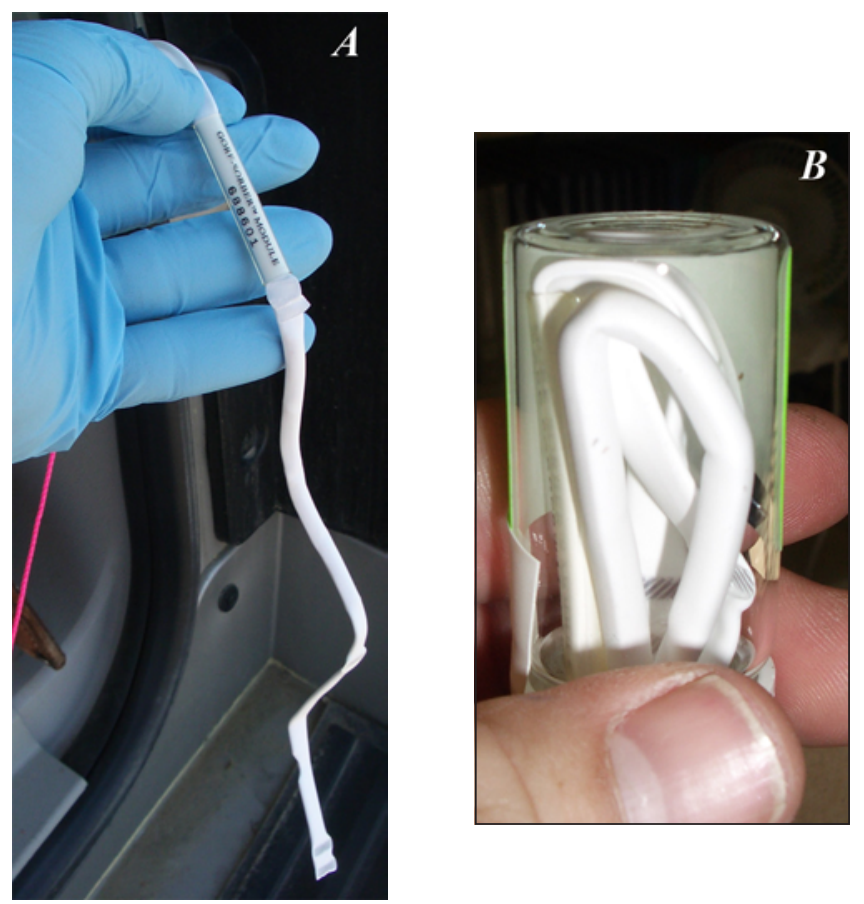

Figure 2. Soil-gas sampler $A$, prior to being installed in a shallow borehole; and $B$, following retrieval from a borehole and prior to shipping to the laboratory for analysis.

\section{Passive Groundwater Wells Survey}

Three monitoring wells were installed at the VATF in 2006 by Fort Gordon personnel to obtain an operating permit for a mixed nondomestic waste-septic system (Noel G. Simmons, P.G., State of Georgia, Department of Natural Resources, Environmental Protection Division, Georgia Geologic Survey, written commun., October 10, 2006). In addition, a discontinued U.S. Geological Survey monitoring well 332020082163101, 27AA02 located at the VATF was included in this study. Modules were installed in the four groundwater wells at the VATF on February 26, 2010 (fig. 3). The modules were placed below the water surface in the wells and removed after about 10 to 15 minutes because of the odor of petroleum products in the well. Three additional samplers were used as trip blanks, and one additional sampler was used as a method blank; these samplers were not deployed. The results of the passive groundwater survey are expressed in concentrations of contaminant in micrograms per liter $(\mu \mathrm{g} / \mathrm{L})$.

\section{Passive Soil-Gas Survey, June 2010}

A total of 72 modules were deployed in a grid pattern to cover the generalized extent of the VATF (fig. 3). Two additional samplers were used as trip blanks, and four samplers were used as method blanks; these samplers were not deployed. Each sampler was placed in a borehole, created by a stainless-steel ship auger attached to a cordless drill, measuring 0.5 inch (in.) in diameter and 15 -in. long. This depth is similar to what is recommended by the USEPA for soil-gas investigations (U.S. Environmental Protection Agency, 1998). The auger was cleaned with a paper towel prior to the drilling of each borehole. The 72 modules were installed on June 3, 2010, and were removed on June 9, 2010. The soilgas contaminant results are expressed as mass of contaminant in micrograms $(\mu \mathrm{g})$.

\section{Passive Soil-Gas Survey, July 2011}

In July 2011, an additional 31 soil-gas samplers were deployed (fig. 3) using the same method described above. These samplers were deployed after the results of the previously deployed 72 soil-gas samplers were received to better define the extent of the contamination. Two of the 31 samplers were deployed within a fenced area adjacent to several buildings. Part of this area is covered by a concrete slab; consequently, some of the samplers were deployed by drilling a hole through the concrete. The samplers were deployed on July 14, 2011, and retrieved on July 18, 2011. The soil-gas contaminant results are expressed as mass of contaminant in micrograms.

\section{Explosives and Chemicals Agents}

Subsequent to the 2010 soil-gas survey, four locations with elevated contaminant mass were selected as sampling sites for organic compounds classified as explosives and for chemical agents (fig. 4). On September 15, 2010, four soil-gas samplers were deployed in the VATF at those selected locations and removed on September 22, 2010. These samplers were installed and retrieved, as previously described in the passive soil-gas survey, and analyzed for organic compounds classified as explosives and chemical agents. The results of the explosives and chemical agents survey are expressed in mass of contaminant in micrograms.

\section{Soil Samples}

Soil samples were collected at the same four locations that were sampled for explosives and chemical agents. In addition, a soil sample was collected at a fifth location in the VATF that was selected using the results of the soil-gas survey to identify an area of elevated contaminant mass. Composite soil samples were collected on August 25, 2010, from land surface to 6 in. below land surface at the five locations (fig. 4). These soil samples were analyzed for 37 metals, including 6 of the 8 Resource Conservation and Recovery Act (RCRA) metals (selenium and mercury were excluded). Soil-sample metal concentrations were compared to the USEPA Regional Screening Levels (RSL) for Industrial Soils (U.S. Environmental Protection Agency, 2009) to determine the extent of contamination. Soil-sample metal concentrations also were compared to values for ambient, uncontaminated (background) levels for soils across the adjacent State of South Carolina (South Carolina Department of Health and Environmental 


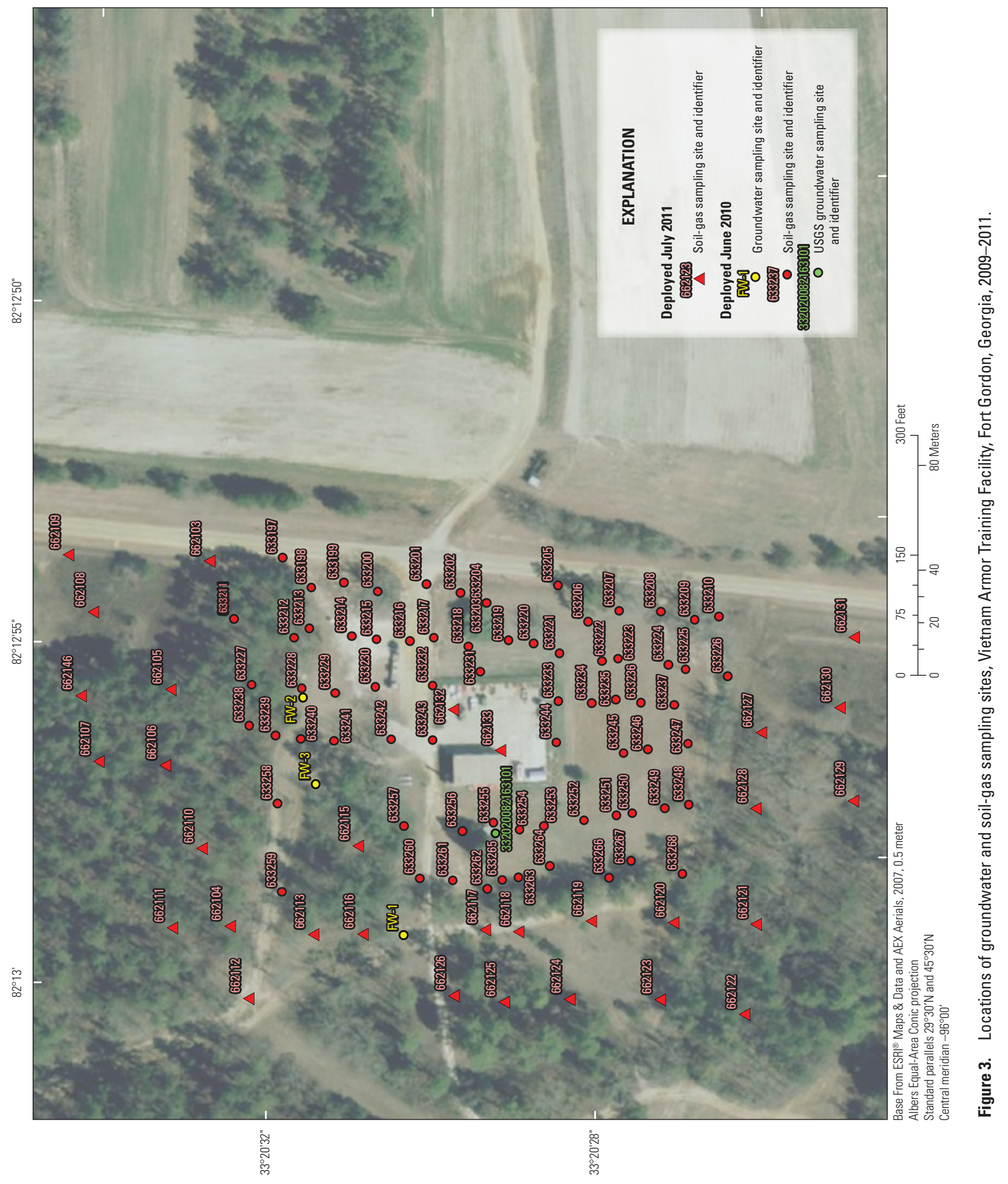




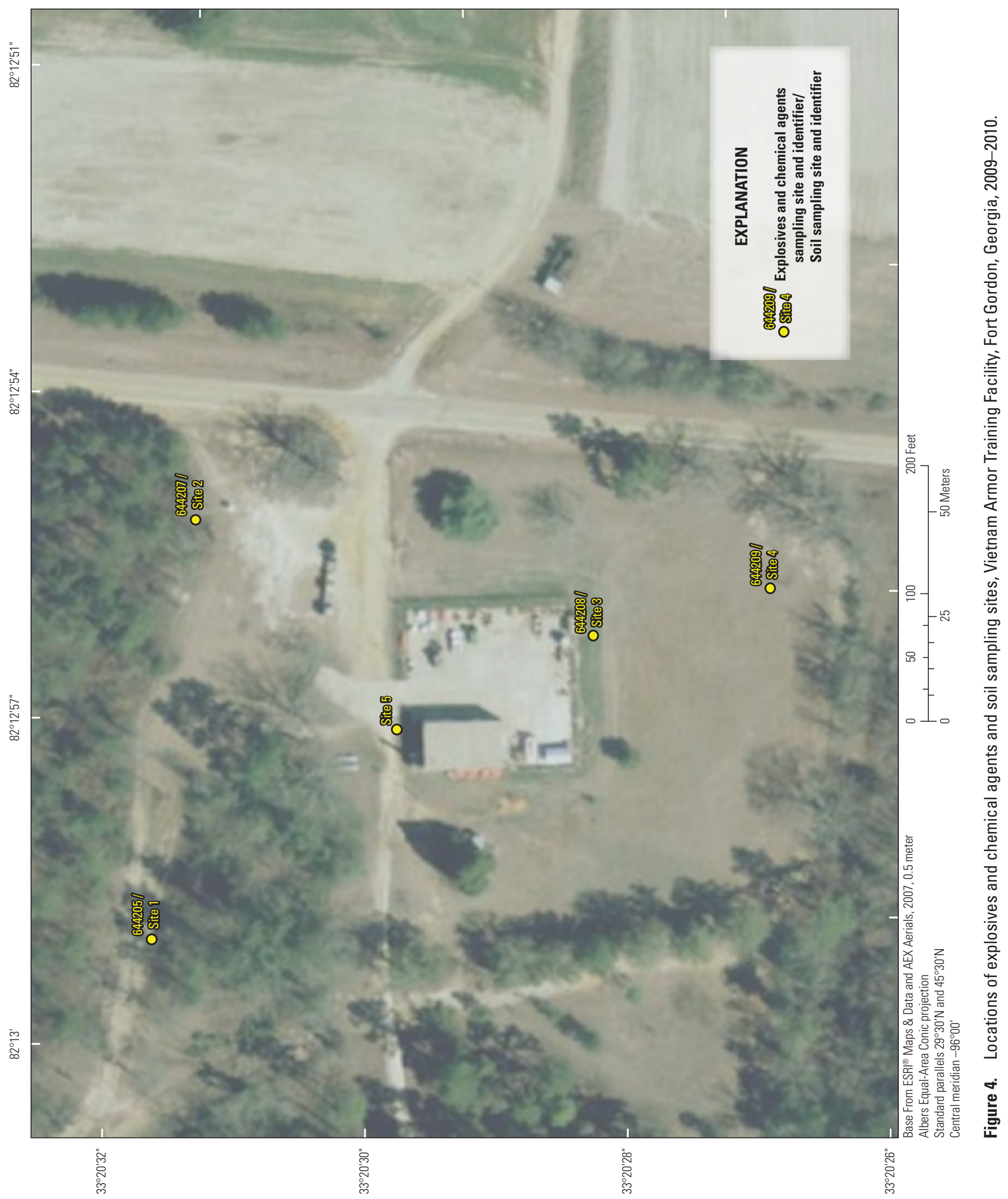


Control, 2002), because no similar values were available for Georgia. The comparison remains valid, because Georgia and South Carolina are located in similar physiographic provinces. Soil samples were analyzed for inorganic compounds using methods described by Briggs and Meier (2002).

\section{Results}

The results of the multiple passive surveys and soil samples are presented in this section of the report. Passive survey results can indicate the presence of particular contaminants. The results do not, however, reveal if the detection was derived from a free product, a residual-phase adsorbed material or vapors in the unsaturated zone, or the dissolved phase in shallow and deep groundwater (unless the module had been placed in water). In general, higher mass in a sample tends to be related to the presence of residual contamination or free product that is close to the land surface where the sampler is located. If such source material were located at greater depths, however, the contaminant mass generally would be lower. A lower value near known sources of contaminants could be caused by various attenuation processes that affect the mass prior to detection. In both cases, however, the modules help to rapidly indicate the presence or absence of contaminants. The passive approach was approved for use at the VATF site by the Hazardous Waste Management Branch, Georgia Environmental Protection Department (William Powell, P.E., Environmental Engineer, Department of Defense Remediation Unit, oral commun., December 10, 2008).

\section{Passive Groundwater Survey}

All four modules deployed in groundwater at the VATF wells detected TPH concentrations greater than the method detection level (MDL) of $2.32 \mu \mathrm{g} / \mathrm{L}$ (fig. 5; table 1). Concentrations of TPH ranged from 708.35 to $4,443.11 \mu \mathrm{g} / \mathrm{L}$. Benzene and octane also were detected above their MDLs in all four samplers (figs. 6 and 7; table 1). The alkanes, undecane (sampling sites FW-2 and FW-3) and pentadecane (sampling sites FW-2 and USGS 332020082163101), were detected above their MDLs in two of the four samplers. The sampling locations and combined concentrations of undecane, tridecane, and pentadecane $\left(\mathrm{C}_{11}, \mathrm{C}_{13}\right.$, and $\left.\mathrm{C}_{15}\right)$ are shown in figure 8. No other VOCs were detected in the groundwater samplers. Pentadecane and TPH were detected in one of the three trip blanks (sampler number 618544), but were at levels below their MDL and above the nondetection level.

\section{Passive Soil-Gas Survey, June 2010}

A total of 71 of the 72 soil-gas samplers (modules) deployed at the VATF detected TPH mass greater than the MDL of $0.02 \mu \mathrm{g}$ (fig. 9; table 2). Soil-gas sampler number
633257 was destroyed and therefore not analyzed. The highest soil-gas TPH mass was $20.98 \mu \mathrm{g}$ and was located at sample number 633226 . The TPH mass ranged from 0.16 to $20.98 \mu \mathrm{g}$. The two trip blanks and three method blanks also detected $\mathrm{TPH}$ above the MDL, but at a mass ranging from 0.03 to $0.07 \mu \mathrm{g}$. The TPH masses detected in the trip and method blanks were considerably smaller than the masses detected in the samplers; therefore, the results of the environmental sample are considered reliable. BTEX was detected in 31 of the 71 samples in the VATF above the MDL (fig. 10; table 2) Benzene and toluene were the main components of the BTEX masses detected above their MDL; each was detected in 20 samplers, but total xylene also was detected at two samplers (sampler numbers 633231 and 633254, table 2). The two PAHs, naphthalene (sampler numbers 633231 and 633259) and 2-methyl-napthalene (sampler number 633231), also were detected above their MDL (table 2). Tridecane was the only alkane detected above its MDL (sampler number 633259). Undecane, tridecane, and pentadecane also were detected at several locations below their MDL but above the nondetection level (table 2). Other VOCs detected in the soil-gas survey above their MDL included 1,2,4-trimethylbenzene at sampler number 633231 and PCE at sampler number 633254.

\section{Passive Soil-Gas Survey, July 2011}

The results of the additional 31 soil-gas samplers deployed in July 2011 suggest that the contamination is prevalent beyond the initial deployment of the 72 soil-gas samplers. All 31 samplers detected TPH above its MDL of $0.02 \mu \mathrm{g}$ (fig. 11; table 3). All three trip blanks and one of the two method blanks detected TPH above its MDL of $0.02 \mu \mathrm{g}$, with the highest mass being $0.13 \mu \mathrm{g}$ (sampler 662144). Censoring of soil-gas results can be difficult because the results are not quantitative, but they do suggest the presence of the constituent. For TPH, the mass detected below the level of $0.13 \mu \mathrm{g}$ is considered questionably valid. However, the values of TPH two times greater than the value detected in the trip blank $(0.26 \mu \mathrm{g})$ are considered likely to be an environmental sample. TPH values greater than $13 \mu \mathrm{g}$, or ten times than the value detected in the trip blank, are most likely to be representative of environmental conditions. There were five locations where TPH were detected above $13 \mu \mathrm{g}$ (sampler numbers 662110 , 662121, 662132, 662133, and 662146). BTEX was detected in 17 of the 31 samplers (fig. 12; table 3), which included benzene in 15 of the 31 samplers, toluene in 8 of the 31 samplers, and total xylenes in 1 of the 31 samplers. The PAHs, naphthalene (sampler numbers 662132, and 662133) and 2-methyl naphthalene (sampler numbers 6621132, and 662133), were detected above their MDLs. The combined masses of the alkanes: undecane, tridecane, and pentadecane were detected above their MDLs in 5 samplers $(662107,662117,662120$, 662132, and 662133), and octane in 1 sampler (number 662133). Other organic compound masses detected above their MDLs were trimethylbenzene (sampler numbers 662121 and 


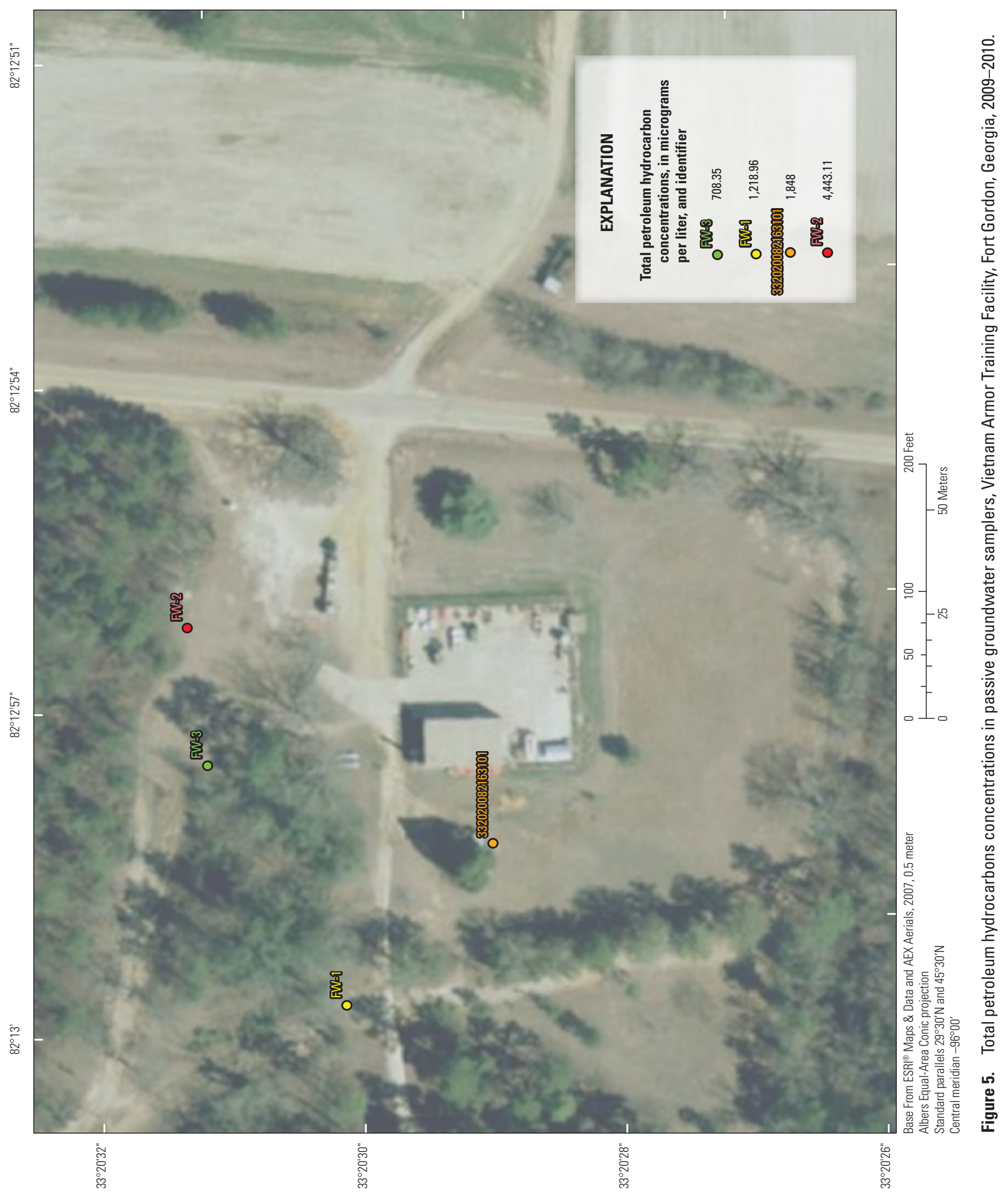


662133), 1,2,4-trimethybenzene (sampler numbers 662121 and 662133), 1,3,5-trimethylbenzene (sampler number 662133), chloroform (sampler numbers 662106, and 662118), and PCE (sampler number 662132). Samplers 662132 and 662133 were deployed respectively within a fenced-in area under a concrete slab adjacent to several buildings. The results from these 2 samplers show that the TPH, benzene, toluene, m-,p-xylene, o-xylene, naphthalene, 2-methylnaphthalene, octane, undecane, tridecane, pentadecane, trimethylbenzene, 1,2,4-trimethylbenzene, 1,3,5-trimethylbenzene, and PCE were all detected above their MDLs, which means that more constituents were detected in these 2 samplees than from all of the other samplers.

\section{Explosives and Chemical Agents}

Four soil-gas samplers installed at selected locations at the VATF and analyzed for the presence of organic compounds classified as explosives or chemical agents (fig. 4) had no detections above their respective MDLs (table 4). One organic compound (explosive and chemical agent), benzothiazole, had masses below its MDL but above its nondetection level (table 4). Para-chlorophenyl methyl sulfone was detected above its MDL in all six samplers but also was detected above its MDL in all five trip blanks, and therefore, the results are not reliable. No other organic compounds classified as explosives and chemical agents were detected in the trip blanks.

\section{Soil Samples}

Five composite soil samples were collected at selected locations at the VATF (fig. 4). The soil samples detected no metal concentrations above the RSLs (tables 5-9). Some metal concentrations, however, were higher than background conditions reported for similar Coastal Plain sediments in South Carolina (South Carolina Department of Health and Environmental Control, 2002). These metals include aluminum, arsenic, barium, beryllium, calcium, chromium, copper, iron, lead, magnesium, manganese, nickel, potassium, sodium, and zinc (tables 5-9). 


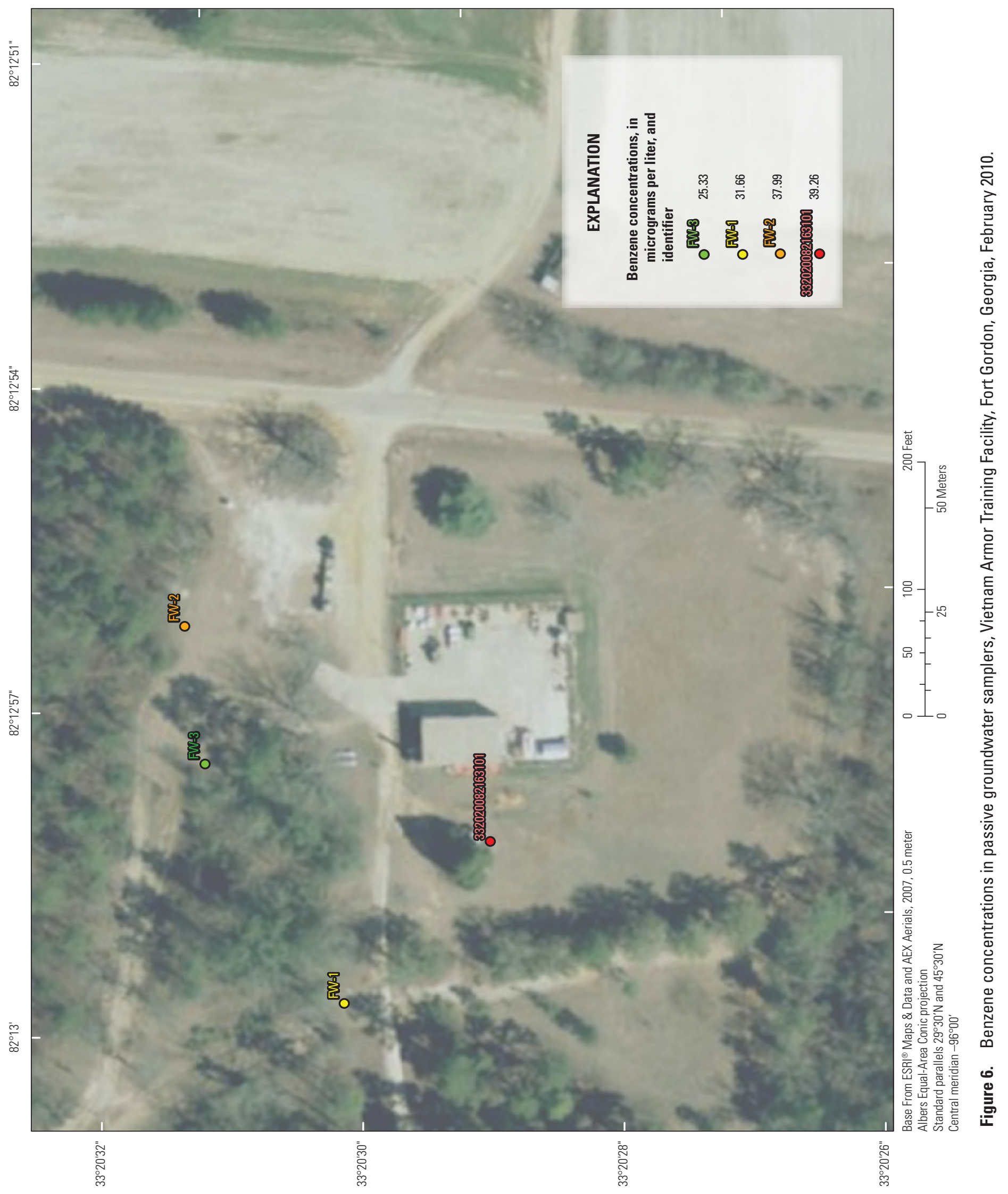




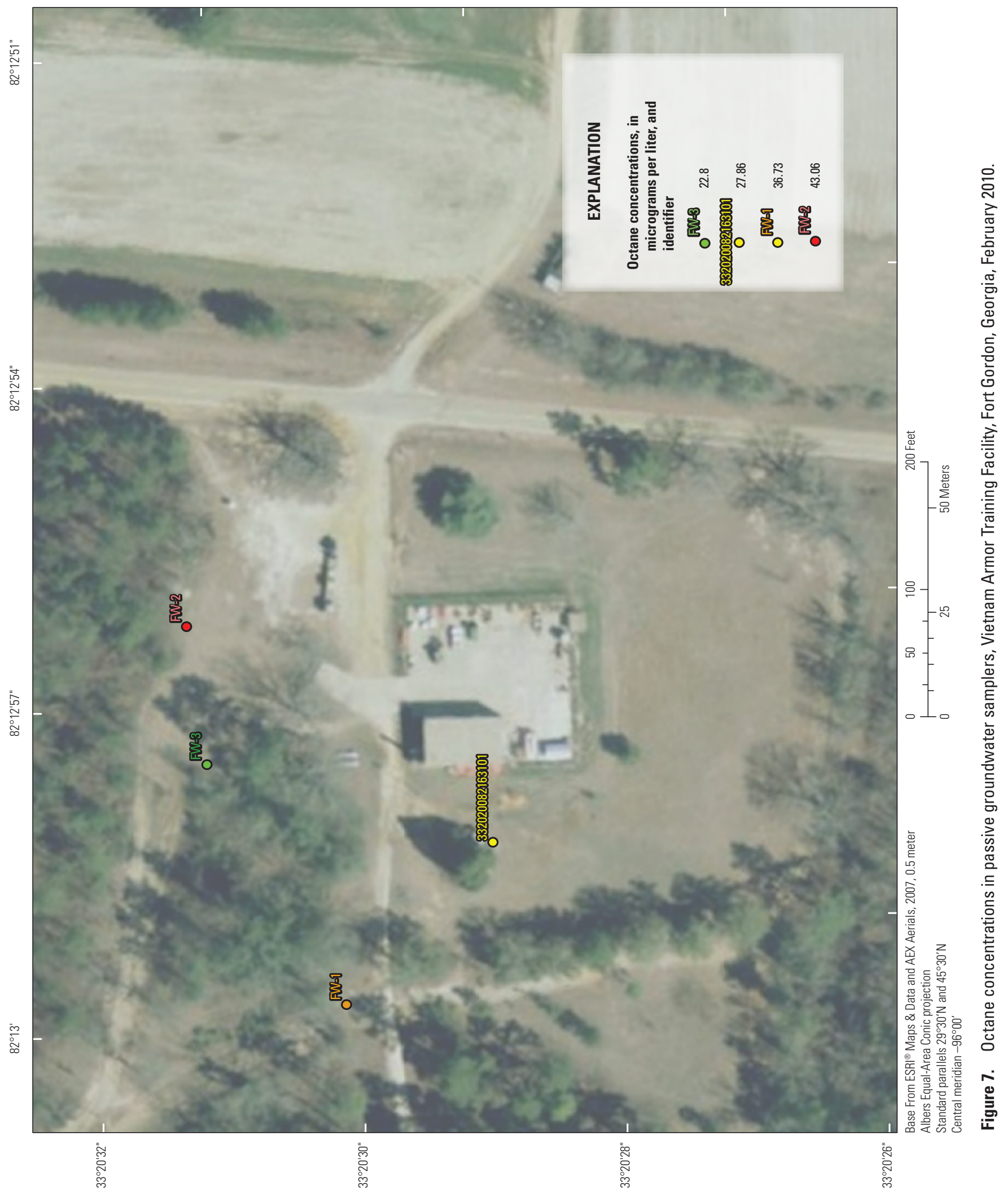




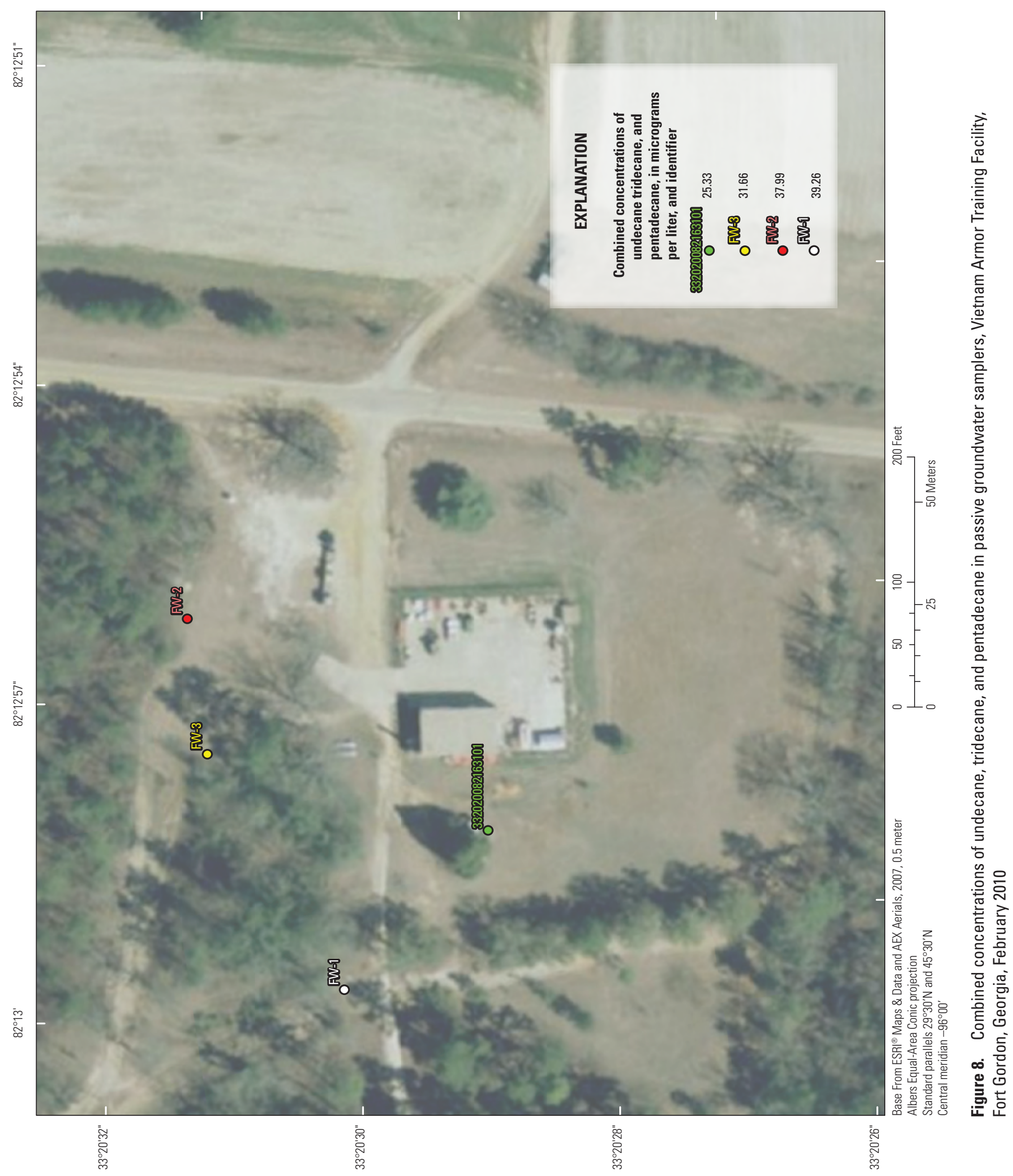




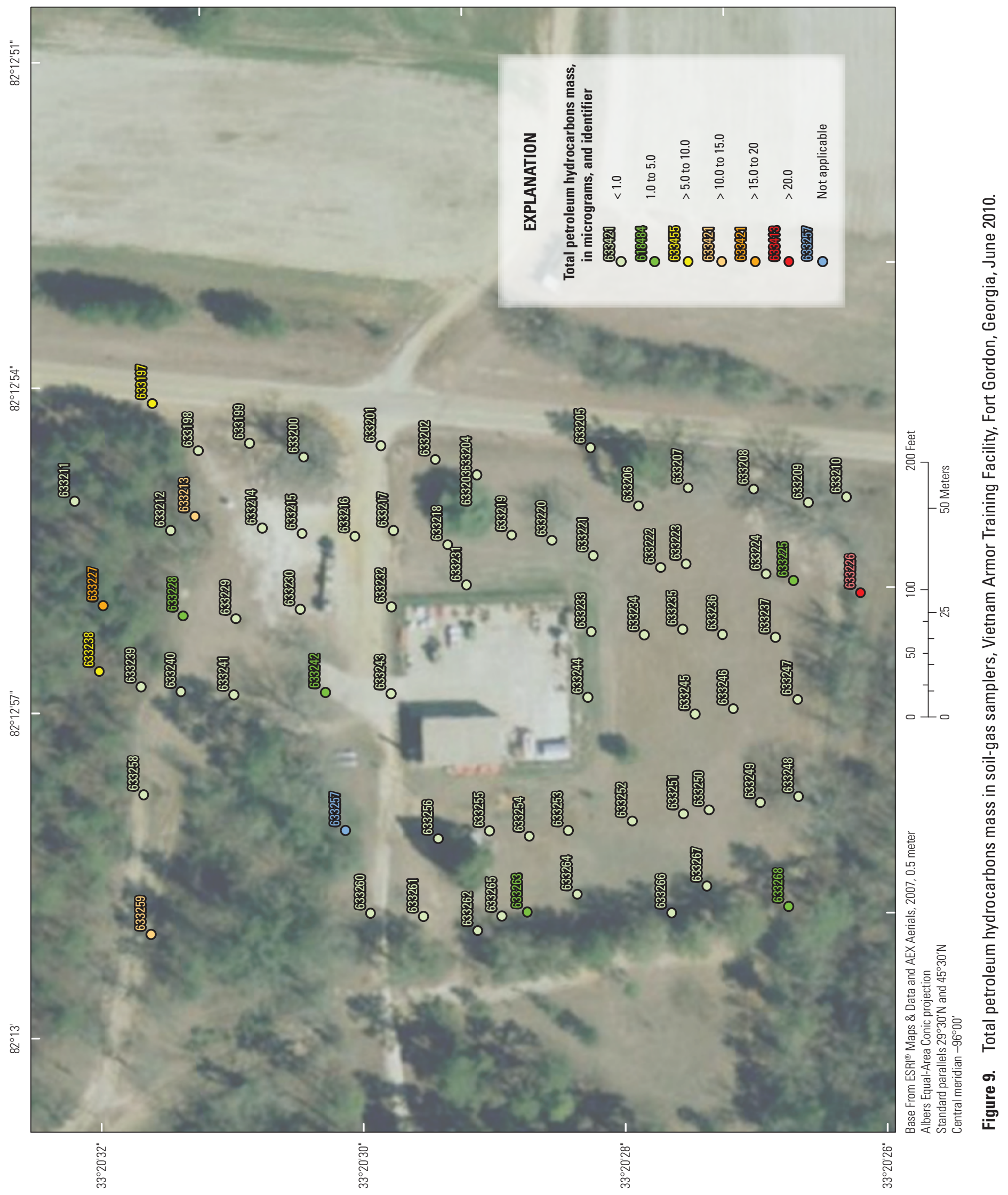




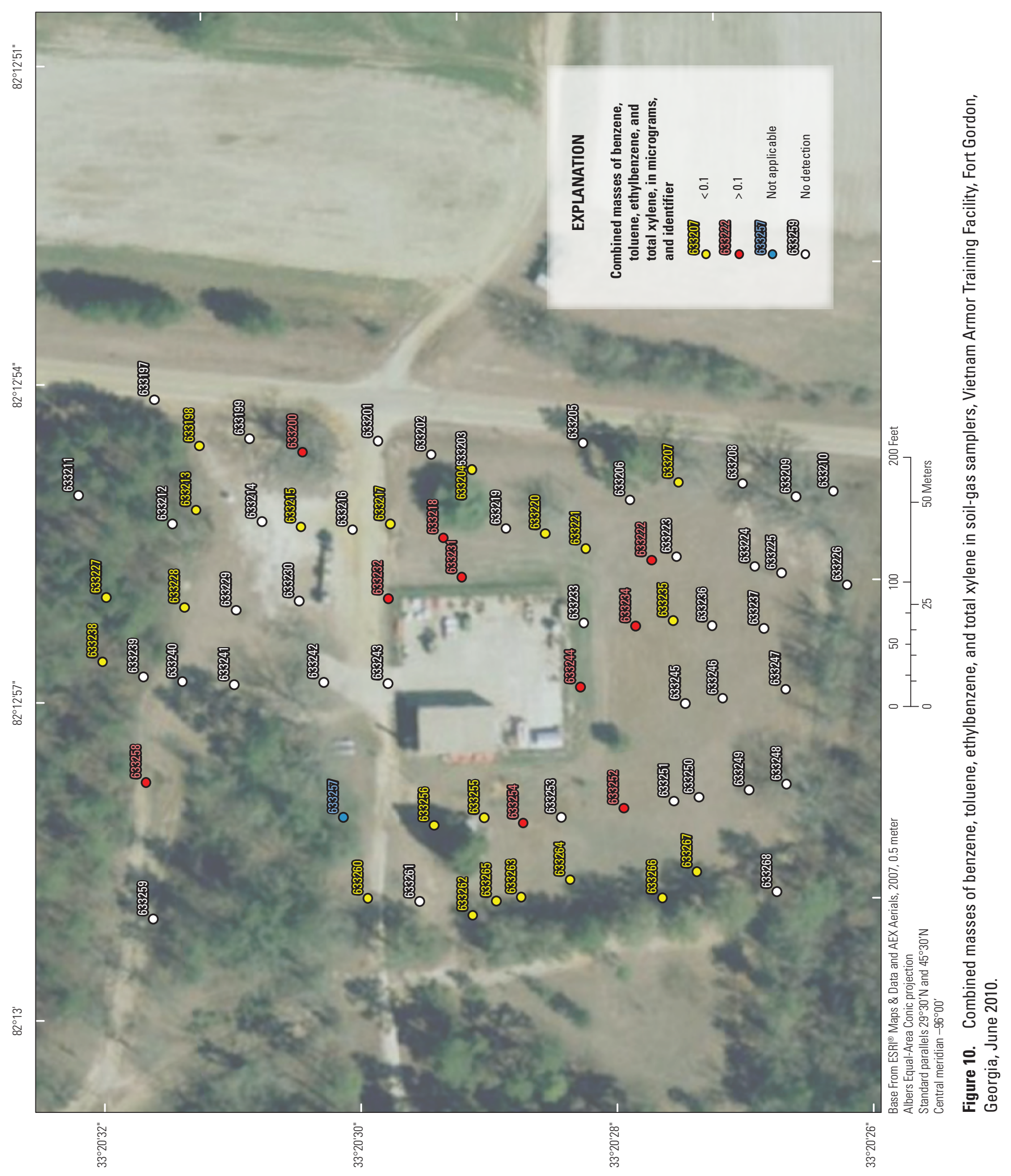




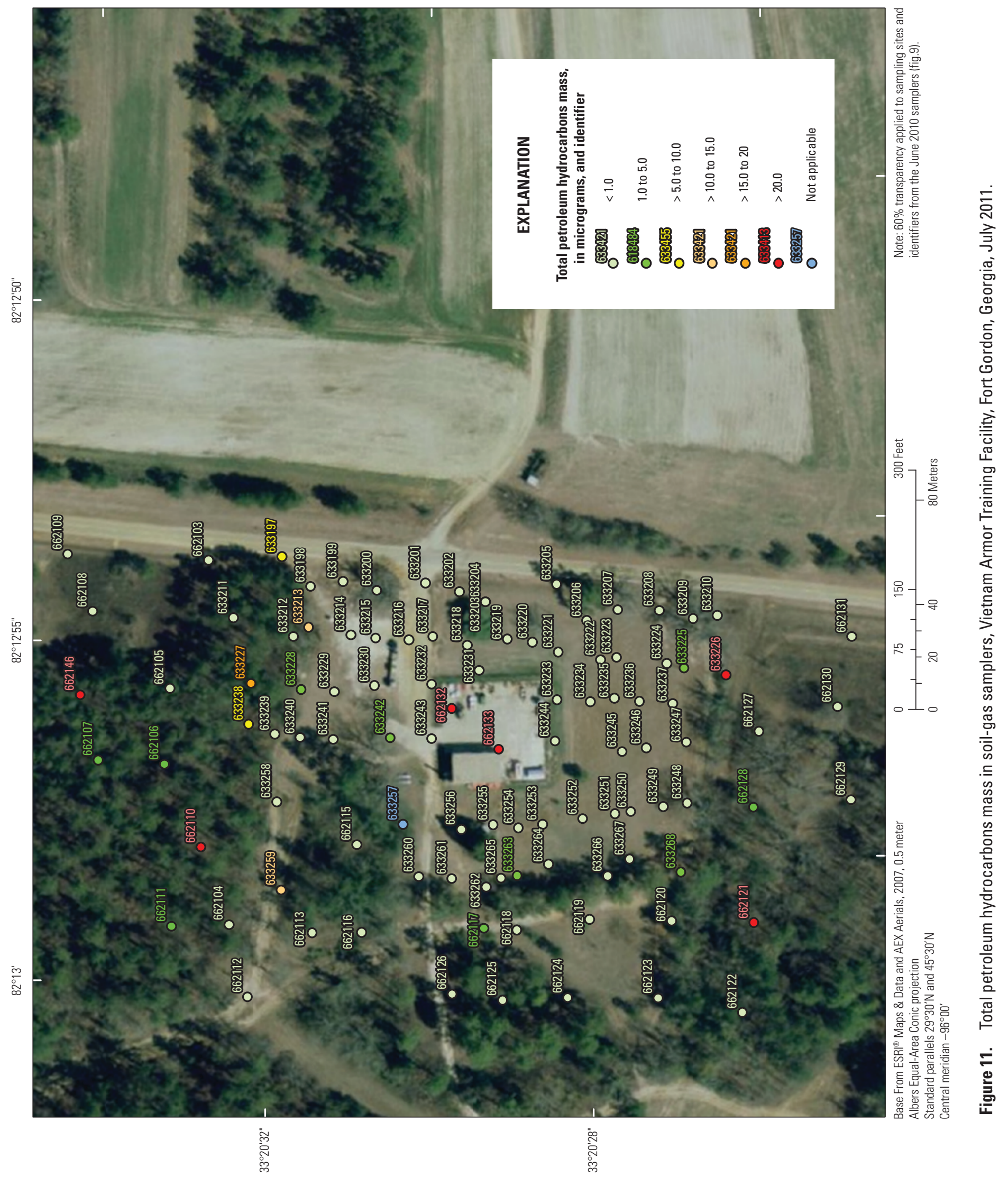




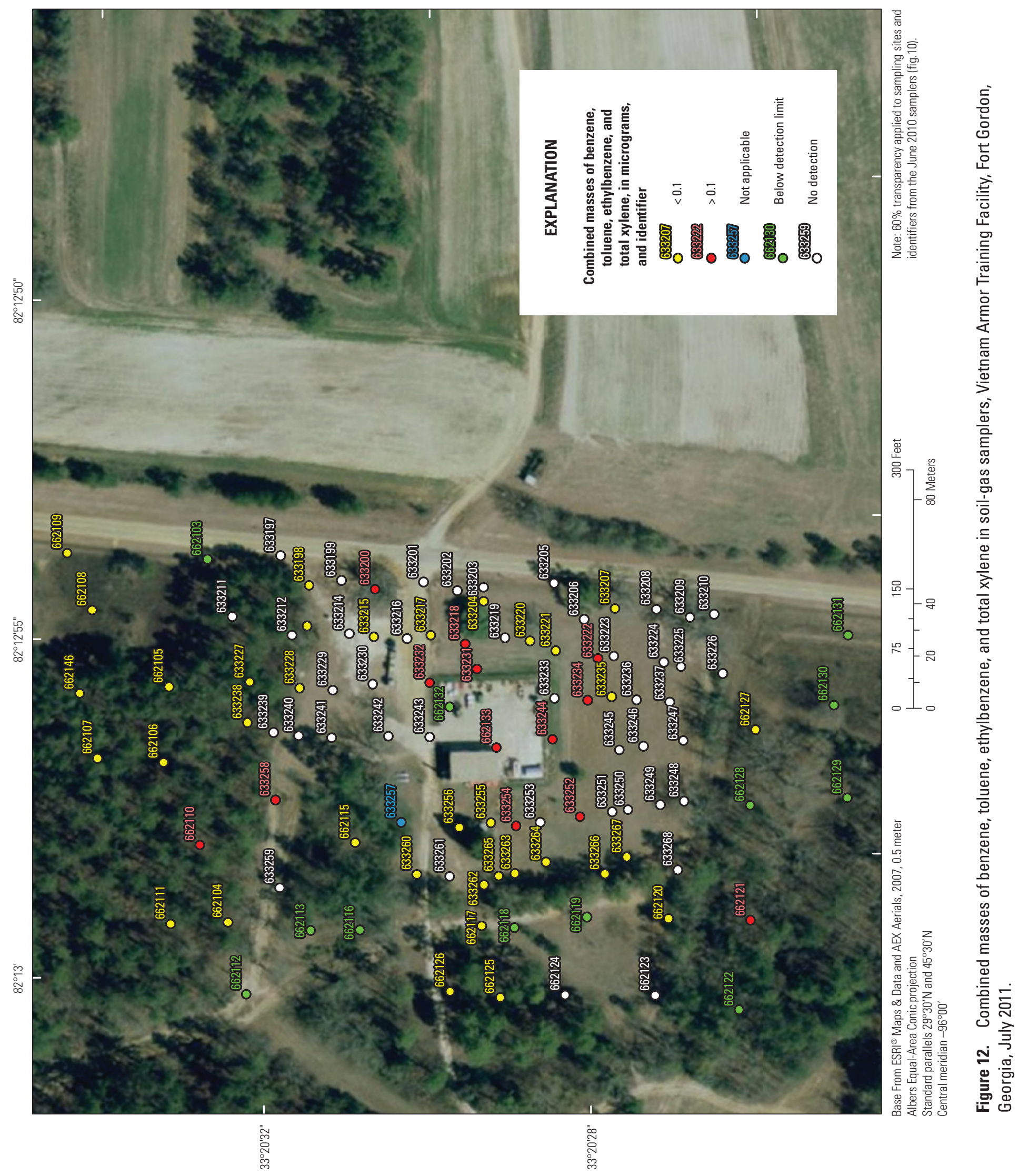




\section{Summary}

The U.S. Geological Survey, in cooperation with the Environmental and Natural Resources Management Office of the U.S. Army Signal Center and Fort Gordon, initially assessed groundwater, soil gas, and soil for contaminants at the Vietnam Armor Training Facility (VATF) at Fort Gordon, Georgia, from October 2009 to September 2010. The assessment included the detection of organic compounds in the groundwater wells and in the soil gas as well as the detection of organic compounds classified as explosives and chemical agents in selected locations. Inorganic compounds were assessed in the soil. The assessment was conducted to provide environmental contamination data to the U.S. Army at Fort Gordon pursuant to requirements of the Resource Conservation and Resources Act Part B Hazardous Permit process.

Passive samplers were deployed in four groundwater wells in the VATF. The samplers detected total petroleum hydrocarbons (TPH), benzene, and octane concentrations, above their method detection levels at all four wells. The only other compounds detected above their method detection levels were the alkanes, undecane and pentadecane, which were detected at two of the four samplers. A total of 72 passive soilgas samplers were deployed across the VATF in June 2010, and TPH mass was detected above the method detection level in 71 of the 72 samplers (one sampler was destroyed in the field and not analyzed); whereas, BTEX (combined masses of benzene, toluene, ethylbenzene, and total xylene) was detected above the method detection level in 31 of the 71 samplers that were analyzed. Other volatile organic compounds detected above their respective method detection levels in the soil-gas survey included naphthalene, 2-methyl-naphthelene, tridecane, 1,2,4-trimethylbenzene, and perchloroethylene.
An additional 31 passive soil-gas samplers were deployed in July 2011 after the results of the 71 soil-gas samplers were received. These 31 samplers were deployed to define the extent of the contamination on a larger scale. Of the 31 samplers, TPH was detected above its MDL at all 31 samplers, whereas BTEX was detected at 17 of the 31 samplers. Other organic compounds detected above their MDLs were naphthalene, 2-methylnaphthalene, octane, undecane, tridecane, pentadecane, 1,2,4-trmethylbenzene, 1,3,5-trimethylbenzene, chloroform, and perchloroethylene.

Subsequent to the 2010 soil-gas survey, four areas determined to have elevated contaminant mass were selected and sampled for organic compounds classified as explosives and chemical agents. The results of this survey detected no organic compounds (explosives and chemical agents) above their respective method detection levels. One of the explosives and chemical agents, benzothiazole, was detected below its method detection level but above the nondetection level.

The same four locations that were sampled for organic compounds classified as explosives and chemical agents were selected for the collection of soil samples. A soil sample also was collected at a fifth location, which was selected using the results of the soil-gas survey to identify an area with elevated contaminant mass. Soil samples were collected at the five locations of the VATF, and no metals were detected that exceeded the regional screening levels for industrial soils as classified by the U.S. Environmental Protection Agency. The soil samples also were compared to values from the ambient, uncontaminated (background) levels for soils in South Carolina, as classified by the South Carolina Department of Health and Environmental Control. Because South Carolina is adjacent to Georgia and the soils in the Coastal Plain are similar, these comparisons are valid. No similar values are available for Georgia to use for comparison purposes. The metals that were detected above the ambient background levels for South Carolina include aluminum, arsenic, barium, beryllium, calcium, chromium, copper, iron, lead, magnesium, manganese, nickel, potassium, sodium, and zinc. 


\section{References}

American Society for Testing and Materials, 2006, Standard guide for soil gas monitoring in the vadose zone: ASTM D5314-92, $36 \mathrm{p}$.

Briggs, P.H., and Meier, A.L., 2002, The determination of forty-two elements in geological materials by inductively coupled plasma-mass spectrometry, in Taggart J.E., Jr., ed., Analytical methods for chemical analysis of geologic and other materials: U.S. Geological Survey Open-File Report 02-223, chapter I.

Gregory, M.B., Stamey, T.C., and Wellborn, J.B., 2001, Ecological characterization of streams, and fish-tissue analysis for mercury and lead at selected locations, Fort Gordon, Georgia, June 1999 to May 2000: U.S. Geological Survey Open-File Report 01-203, 14 p.

International Organization for Standardization, 1990, ISO guide 25-General requirements for the competence of calibration and testing laboratories ( $3 \mathrm{~d}$ ed.): New York, American National Standards Institute.

South Carolina Department of Health and Environmental Control, 2002, Environmental Surveillance and Oversight Program data report, 2002: Accessed February 11, 2010, at http://www.scdhec.gov/environment/envserv/docs/esop_ datarpt_02.pdf.
U.S. Environmental Protection Agency, 1998, Innovative technology verification report soil gas sampling technology: EPA/600/R-98/095.

U.S. Environmental Protection Agency, 2009, Regional screening level tables: Accessed January 12, 2010, at http:// www.epa.gov/reg3hwmd/risk/human/rb-concentration_ table/Generic_Tables/index.htm.

U.S. Geological Survey, variously dated, National field manual for the collection of water-quality data: U.S. Geological Survey Techniques of Water-Resources Investigations, book 9, chap. A1, January, accessed January 19, 2010, at http://pubs.water.usgs.gov/twri9A1/.

Williams, L.J., 2007, Hydrogeology and potentiometric surface of the Dublin and Midville aquifer systems in Richmond County, Georgia, January 2007: U.S. Geological Survey Scientific Investigations Map 2982, 1 sheet.

W.L. Gore and Associates, Inc., 2004, Surveys for environmental site assessment: Accessed March 19, 2010, at http://www.gore.com/MungoBlobs/239/659/surveys environmental_brochure.pdf. 
Table 1. Concentrations of organic compounds detected in passive groundwater samplers collected from the Vietnam Armor Training Facility, Fort Gordon, Georgia, 2009-2011.

[TPH, total petroleum hydrocarbon; $\mu \mathrm{g} / \mathrm{L}$, microgram per liter; BTEX, combined mass of benzene, toluene, ethylbenzene, and total xylene; m, meta; $\mathrm{p}$, para; o, ortho; MTBE, methyl tert-butyl ether; $\mathrm{C}_{11}, \mathrm{C}_{13}, \mathrm{C}_{15}$, combined concentrations of undecane, tridecane, and pentadecane; DCA, dichlorethane; TCA, trichloroethane; TCE, trichloroethylene; PCE, perchloroethylene; DCE, dichloroethylene; $\mathrm{CCl}_{4}$, carbon tetrachloride; DCB, dichlorobenzene; MDL, method detection level; nd, not detected; USGS, U.S. Geological Survey; below detection level]

\begin{tabular}{|c|c|c|c|c|c|c|c|c|}
\hline $\begin{array}{l}\text { Groundwater } \\
\text { sampling site }\end{array}$ & $\begin{array}{l}\text { Sampler } \\
\text { number }\end{array}$ & $\begin{array}{c}\text { TPH } \\
(\mu g / L)\end{array}$ & $\begin{array}{l}\text { BTEX }^{a} \\
(\mu \mathrm{g} / \mathrm{L})\end{array}$ & $\begin{array}{c}\text { Benzene } \\
(\mu \mathrm{g} / \mathrm{L})\end{array}$ & $\begin{array}{c}\text { Toluene } \\
\text { ( } \mu \mathrm{g} / \mathrm{L})\end{array}$ & $\begin{array}{c}\text { Ethyl } \\
\text { benzene } \\
\text { ( } \mu \mathrm{g} / \mathrm{L})\end{array}$ & $\begin{array}{c}\text { m-, p-Xylene } \\
\text { ( } \mu \mathrm{g} / \mathrm{L})\end{array}$ & $\begin{array}{c}\text { o-Xylene } \\
\text { ( } \mu \mathrm{g} / \mathrm{L})\end{array}$ \\
\hline MDL & & 2.32 & & 1.16 & 1.16 & 1.16 & 1.16 & 1.16 \\
\hline FW-1 & 618534 & $1,218.96$ & 31.66 & 31.66 & nd & nd & nd & nd \\
\hline FW-2 & 618533 & $4,443.11$ & 37.99 & 37.99 & nd & nd & nd & nd \\
\hline FW-3 & 618527 & $1,848.00$ & 39.26 & 39.26 & nd & nd & nd & nd \\
\hline $\begin{array}{l}\text { USGS } \\
\quad 332020082163101\end{array}$ & 618535 & 708.35 & 25.33 & 25.33 & nd & nd & nd & nd \\
\hline Trip blank & 618528 & nd & nd & nd & nd & nd & nd & nd \\
\hline Trip blank & 618544 & bdl & nd & nd & nd & nd & nd & nd \\
\hline Trip blank & 618545 & nd & nd & nd & nd & nd & nd & nd \\
\hline Method blank & & nd & nd & nd & nd & nd & nd & nd \\
\hline
\end{tabular}

Table 1. Concentrations of organic compounds detected in passive groundwater samplers collected from the Vietnam Armor Training Facility, Fort Gordon, Georgia, 2009-2011.—Continued

[TPH, total petroleum hydrocarbon; $\mu \mathrm{g} / \mathrm{L}$, microgram per liter; BTEX, combined mass of benzene, toluene, ethylbenzene, and total xylene; m, meta; $p$, para; o, ortho; MTBE, methyl tert-butyl ether; $\mathrm{C}_{11}, \mathrm{C}_{13}, \mathrm{C}_{15}$, combined concentrations of undecane, tridecane, and pentadecane; DCA, dichlorethane; TCA, trichloroethane; TCE, trichloroethylene; PCE, perchloroethylene; DCE, dichloroethylene; $\mathrm{CCl}_{4}$, carbon tetrachloride; $\mathrm{DCB}$, dichlorobenzene; $\mathrm{MDL}$, method detection level; nd, not detected; USGS, U.S. Geological Survey; below detection level]

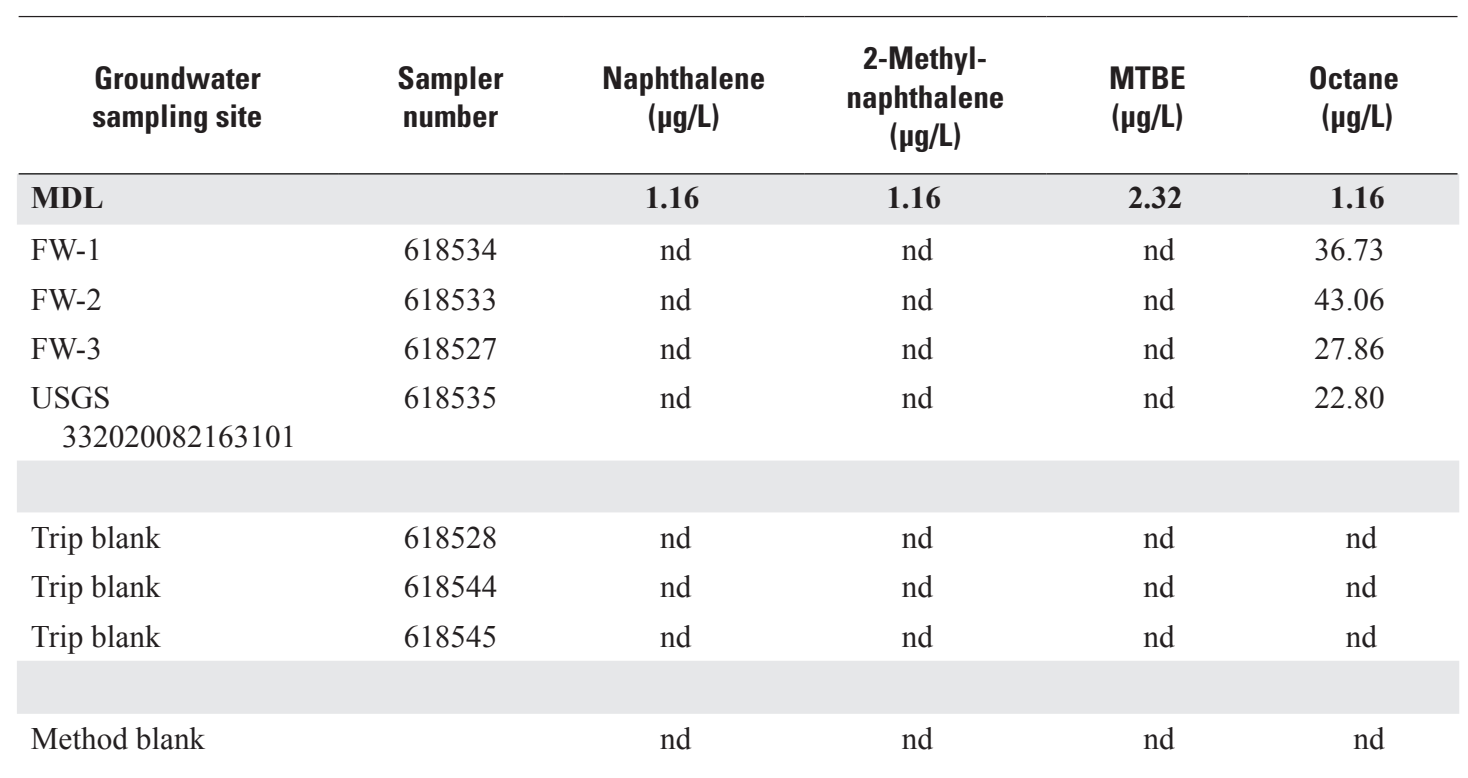


Table 1. Concentrations of organic compounds detected in passive groundwater samplers collected from the Vietnam Armor Training Facility, Fort Gordon, Georgia, 2009-2011._Continued

[TPH, total petroleum hydrocarbon; $\mu \mathrm{g} / \mathrm{L}$, microgram per liter; BTEX, combined mass of benzene, toluene, ethylbenzene, and total xylene; m, meta; $p$, para; o, ortho; MTBE, methyl tert-butyl ether; $\mathrm{C}_{11}, \mathrm{C}_{13}, \mathrm{C}_{15}$, combined concentrations of undecane, tridecane, and pentadecane; DCA, dichlorethane; TCA, trichloroethane; TCE, trichloroethylene; PCE, perchloroethylene; DCE, dichloroethylene; $\mathrm{CCl}_{4}$, carbon tetrachloride; $\mathrm{DCB}$, dichlorobenzene; MDL, method detection level; nd, not detected; USGS, U.S. Geological Survey; below detection level]

\begin{tabular}{|c|c|c|c|c|c|}
\hline $\begin{array}{l}\text { Groundwater } \\
\text { sampling site }\end{array}$ & $\begin{array}{l}\text { Sampler } \\
\text { number }\end{array}$ & $\begin{array}{c}C_{11^{\prime}}, C_{13^{\prime}} C_{15}{ }^{a} \\
(\mu \mathrm{g} / \mathrm{L})\end{array}$ & $\begin{array}{l}\text { Undecane } \\
(\mu \mathrm{g} / \mathrm{L})\end{array}$ & $\begin{array}{l}\text { Tridecane } \\
(\mu \mathrm{g} / \mathrm{L})\end{array}$ & $\begin{array}{c}\text { Pentadecane } \\
(\mu \mathrm{g} / \mathrm{L})\end{array}$ \\
\hline MDL & & & 1.16 & 1.16 & 1.16 \\
\hline FW-1 & 618534 & nd & nd & nd & nd \\
\hline FW-2 & 618533 & 31.66 & 29.13 & nd & 2.53 \\
\hline FW-3 & 618527 & 15.20 & 15.20 & nd & nd \\
\hline $\begin{array}{l}\text { USGS } \\
\quad 332020082163101\end{array}$ & 618535 & 2.53 & nd & nd & 2.53 \\
\hline Trip blank & 618528 & nd & nd & nd & nd \\
\hline Trip blank & 618544 & nd & nd & nd & bdl \\
\hline Trip blank & 618545 & nd & nd & nd & nd \\
\hline Method blank & & nd & nd & nd & nd \\
\hline
\end{tabular}

Table 1. Concentrations of organic compounds detected in passive groundwater samplers collected from the Vietnam Armor Training Facility, Fort Gordon, Georgia, 2009-2011._Continued

[TPH, total petroleum hydrocarbon; $\mu \mathrm{g} / \mathrm{L}$, microgram per liter; BTEX, combined mass of benzene, toluene, ethylbenzene, and total xylene; m, meta; $\mathrm{p}$, para; o, ortho; MTBE, methyl tert-butyl ether; $\mathrm{C}_{11}, \mathrm{C}_{13}, \mathrm{C}_{15}$, combined concentrations of undecane, tridecane, and pentadecane; DCA, dichlorethane; TCA, trichloroethane; TCE, trichloroethylene; PCE, perchloroethylene; DCE, dichloroethylene; $\mathrm{CCl}_{4}$, carbon tetrachloride; DCB, dichlorobenzene; MDL, method detection level; nd, not detected; USGS, U.S. Geological Survey; below detection level]

\begin{tabular}{|c|c|c|c|c|c|c|c|c|}
\hline $\begin{array}{l}\text { Groundwater } \\
\text { sampling site }\end{array}$ & $\begin{array}{l}\text { Sampler } \\
\text { number }\end{array}$ & $\begin{array}{c}\text { Trimethyl } \\
\text { benzene }^{\mathrm{a}} \\
\text { ( } \mu \mathrm{g} / \mathrm{L})\end{array}$ & $\begin{array}{l}\text { 1,2,4-Trimethyl } \\
\text { benzene } \\
(\mu \mathrm{g} / \mathrm{L})\end{array}$ & $\begin{array}{l}\text { 1,3,5-Trimethyl } \\
\text { benzene } \\
(\mu \mathrm{g} / \mathrm{L})\end{array}$ & $\begin{array}{c}1,1-D C A \\
(\mu \mathrm{g} / \mathrm{L})\end{array}$ & $\begin{array}{c}\text { Chloro- } \\
\text { form } \\
\text { ( } \mu \mathrm{g} / \mathrm{L})\end{array}$ & $\begin{array}{c}1,1,1-\mathrm{TCA} \\
(\mu \mathrm{g} / \mathrm{L})\end{array}$ & $\begin{array}{c}\text { 1,2-DCA } \\
(\mu \mathrm{g} / \mathrm{L})\end{array}$ \\
\hline FW-1 & 618534 & nd & nd & nd & nd & nd & nd & nd \\
\hline FW-2 & 618533 & nd & nd & nd & nd & nd & nd & nd \\
\hline $\begin{array}{l}\text { USGS } \\
\quad 3302020082163101\end{array}$ & 618535 & nd & nd & nd & nd & nd & nd & nd \\
\hline Trip blank & 618528 & nd & nd & nd & nd & nd & nd & nd \\
\hline Trip blank & 618544 & nd & nd & nd & nd & nd & nd & nd \\
\hline
\end{tabular}


Table 1. Concentrations of organic compounds detected in passive groundwater samplers collected from the Vietnam Armor Training Facility, Fort Gordon, Georgia, 2009-2011.-Continued

[TPH, total petroleum hydrocarbon; $\mu \mathrm{g} / \mathrm{L}$, microgram per liter; BTEX, combined mass of benzene, toluene, ethylbenzene, and total xylene; m, meta; $\mathrm{p}$, para; o, ortho; MTBE, methyl tert-butyl ether; $\mathrm{C}_{11}, \mathrm{C}_{13}, \mathrm{C}_{15}$, combined concentrations of undecane, tridecane, and pentadecane; DCA, dichlorethane; TCA, trichloroethane; TCE, trichloroethylene; PCE, perchloroethylene; DCE, dichloroethylene; $\mathrm{CCl}_{4}$, carbon tetrachloride; DCB, dichlorobenzene; MDL, method detection level; nd, not detected; USGS, U.S. Geological Survey; below detection level]

\begin{tabular}{|c|c|c|c|c|c|c|}
\hline $\begin{array}{l}\text { Groundwater } \\
\text { sampling site }\end{array}$ & $\begin{array}{l}\text { Sampler } \\
\text { number }\end{array}$ & $\begin{array}{c}\text { TCE } \\
(\mu \mathrm{g} / \mathrm{L})\end{array}$ & $\begin{array}{l}\text { PCE } \\
(\mu g / L)\end{array}$ & $\begin{array}{c}\text { C-,t, 1,2-DCE } \\
(\mu \mathrm{g} / \mathrm{L})\end{array}$ & $\begin{array}{c}\text { t-,1,2-DCE } \\
(\mu \mathrm{g} / \mathrm{L})\end{array}$ & $\begin{array}{c}\text { C-1,2-DCE } \\
(\mu \mathrm{g} / \mathrm{L})\end{array}$ \\
\hline MDL & & 1.16 & 1.16 & & 4.01 & 1.20 \\
\hline FW-1 & 618534 & nd & nd & nd & nd & nd \\
\hline FW-2 & 618533 & nd & nd & nd & nd & nd \\
\hline FW-3 & 618527 & nd & nd & nd & nd & nd \\
\hline $\begin{array}{l}\text { USGS } \\
\quad 332020082163101\end{array}$ & 618535 & nd & nd & nd & nd & nd \\
\hline Trip blank & 618528 & nd & nd & nd & nd & nd \\
\hline Trip blank & 618544 & nd & nd & nd & nd & nd \\
\hline Trip blank & 618545 & nd & nd & nd & nd & nd \\
\hline
\end{tabular}

Table 1. Concentrations of organic compounds detected in passive groundwater samplers collected from the Vietnam Armor Training Facility, Fort Gordon, Georgia, 2009-2011._Continued

[TPH, total petroleum hydrocarbon; $\mu \mathrm{g} / \mathrm{L}$, microgram per liter; BTEX, combined mass of benzene, toluene, ethylbenzene, and total xylene; m, meta; $\mathrm{p}$ para; o, ortho; MTBE, methyl tert-butyl ether; $\mathrm{C}_{11}, \mathrm{C}_{13}, \mathrm{C}_{15}$, combined concentrations of undecane, tridecane, and pentadecane; DCA, dichlorethane; TCA, trichloroethane; TCE, trichloroethylene; PCE, perchloroethylene; DCE, dichloroethylene; $\mathrm{CCl}_{4}$, carbon tetrachloride; DCB, dichlorobenzene; $\mathrm{MDL}$, method detection level; nd, not detected; USGS, U.S. Geological Survey; below detection level]

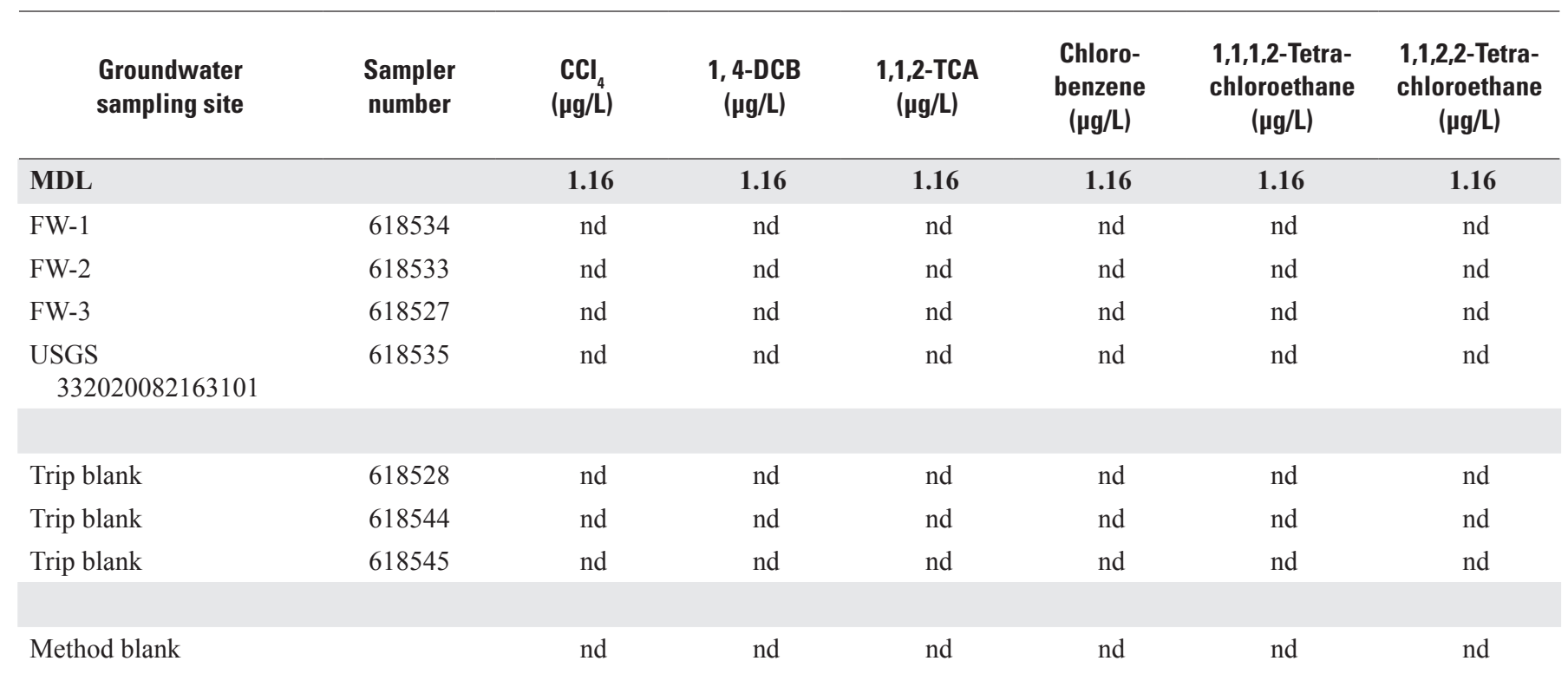


Table 1. Concentrations of organic compounds detected in passive groundwater samplers collected from the Vietnam Armor Training Facility, Fort Gordon, Georgia, 2009-2011.-Continued

$[\mathrm{TPH}$, total petroleum hydrocarbon; $\mu \mathrm{g} / \mathrm{L}$, microgram per liter; BTEX, combined mass of benzene, toluene, ethylbenzene, and total xylene; m, meta; $\mathrm{p}$, para; o, ortho; MTBE, methyl tert-butyl ether; $\mathrm{C}_{11}, \mathrm{C}_{13}, \mathrm{C}_{15}$, combined concentrations of undecane, tridecane, and pentadecane; DCA, dichlorethane; TCA, trichloroethane; TCE, trichloroethylene; PCE, perchloroethylene; DCE, dichloroethylene; $\mathrm{CCl}_{4}$, carbon tetrachloride; DCB, dichlorobenzene; MDL, method detection level; nd, not detected; USGS, U.S. Geological Survey; below detection level]

\begin{tabular}{|c|c|c|c|}
\hline $\begin{array}{l}\text { Groundwater } \\
\text { sampling site }\end{array}$ & $\begin{array}{l}\text { Sampler } \\
\text { number }\end{array}$ & $\begin{array}{c}\text { 1,3-Dichlorobenzene } \\
(\mu \mathrm{g} / \mathrm{L})\end{array}$ & $\begin{array}{c}\text { 1,2-Dichlorobenzene } \\
(\mu \mathrm{g} / \mathrm{L})\end{array}$ \\
\hline MDL & & 1.16 & 1.16 \\
\hline FW-1 & 618534 & nd & nd \\
\hline FW-2 & 618533 & nd & nd \\
\hline FW-3 & 618527 & nd & nd \\
\hline FW-4 & 618535 & nd & nd \\
\hline Trip blank & 618528 & nd & nd \\
\hline Trip blank & 618544 & nd & nd \\
\hline Trip blank & 618545 & nd & nd \\
\hline Method blank & & nd & nd \\
\hline
\end{tabular}

${ }^{\mathrm{a}}$ Combined concentration for two or more compounds with no method detection level provided by laboratory. 
Table 2. Mass of organic compounds detected in soil-gas samplers collected from the Vietnam Armor Training Facility, Fort Gordon, Georgia, June 2010.

[TPH, total petroleum hydrocarbon; $\mu \mathrm{g}$, microgram; BTEX, combined masses of benzene, toluene, ethylbenzene, and total xylenes; m-, meta; p-, para; o-, ortho; MDL, method detection level; nd, not detected; bdl, below detection level; 633269 and 633270 are trip blanks; MTBE, methyl tert-butyl ether; $\mathrm{C}_{11}$, $\mathrm{C}_{13}$, $\mathrm{C}_{15}$, combined masses of undecane, tridecane, and pentadecane; DCA, dichlorethane; TCA, trichloroethane; TCE, trichloroethylene; DCE, dichloroethylene; PCE, perchloroethylene; $\mathrm{DCB}$, dichlorobenzene; $\mathrm{CCl}_{4}$, carbon tetrachloride]

\begin{tabular}{|c|c|c|c|c|c|c|c|}
\hline $\begin{array}{l}\text { Sampler } \\
\text { number }\end{array}$ & $\begin{array}{l}\text { TPH } \\
(\mu g)\end{array}$ & $\begin{array}{l}\text { BTEX }^{a} \\
(\mu \mathrm{g})\end{array}$ & $\begin{array}{c}\text { Benzene } \\
\text { ( } \mu \mathrm{g})\end{array}$ & $\begin{array}{c}\text { Toluene } \\
\text { ( } \mu \mathrm{g})\end{array}$ & $\begin{array}{c}\text { Ethylbenzene } \\
\text { ( } \mu \mathrm{g})\end{array}$ & $\begin{array}{c}\text { m-, p-, Xylene } \\
\text { ( } \mu \mathrm{g})\end{array}$ & $\begin{array}{c}\text { o-Xylene } \\
\text { ( } \mu \mathrm{g})\end{array}$ \\
\hline MDL & 0.02 & & 0.02 & 0.02 & 0.02 & 0.03 & 0.02 \\
\hline 633198 & 0.50 & 0.07 & 0.02 & 0.05 & nd & nd & nd \\
\hline 633199 & 0.47 & nd & nd & nd & nd & nd & nd \\
\hline 633202 & 0.31 & nd & nd & nd & nd & nd & nd \\
\hline 633203 & 3.13 & nd & nd & nd & nd & nd & nd \\
\hline 633204 & 0.38 & 0.02 & nd & 0.02 & nd & nd & nd \\
\hline 633205 & 0.54 & nd & nd & nd & nd & nd & nd \\
\hline 633206 & 0.60 & nd & nd & nd & nd & nd & nd \\
\hline 633210 & 0.35 & nd & nd & nd & nd & nd & nd \\
\hline 633211 & 0.54 & nd & nd & nd & nd & nd & nd \\
\hline 633212 & 1.99 & nd & nd & nd & nd & nd & nd \\
\hline 633213 & 12.27 & 0.04 & nd & 0.04 & nd & nd & nd \\
\hline 633214 & 0.41 & nd & nd & nd & nd & nd & nd \\
\hline 633215 & 0.38 & 0.03 & nd & 0.03 & nd & nd & nd \\
\hline 633216 & 0.55 & nd & nd & nd & nd & nd & nd \\
\hline 633217 & 0.24 & 0.05 & 0.03 & 0.03 & nd & nd & nd \\
\hline 633218 & 0.91 & 0.10 & 0.08 & 0.02 & nd & nd & nd \\
\hline 633219 & 0.48 & nd & nd & nd & nd & nd & nd \\
\hline 633226 & 20.98 & nd & nd & nd & nd & nd & nd \\
\hline 633227 & 15.21 & 0.03 & nd & 0.03 & nd & nd & nd \\
\hline 633228 & 4.48 & 0.04 & nd & 0.04 & nd & nd & nd \\
\hline 633229 & 0.49 & nd & nd & nd & nd & nd & nd \\
\hline 633230 & 0.45 & nd & nd & nd & nd & nd & nd \\
\hline 633231 & 0.43 & 0.13 & nd & nd & nd & 0.08 & 0.05 \\
\hline 633232 & 0.27 & 0.24 & 0.06 & 0.18 & nd & nd & nd \\
\hline 633233 & 0.16 & nd & nd & nd & nd & nd & nd \\
\hline 633234 & 0.52 & 0.11 & 0.11 & nd & nd & nd & nd \\
\hline 633235 & 0.44 & 0.02 & 0.02 & nd & nd & nd & nd \\
\hline
\end{tabular}


Table 2. Mass of organic compounds detected in soil-gas samplers collected from the Vietnam Armor Training Facility, Fort Gordon, Georgia, June 2010.-Continued

[TPH, total petroleum hydrocarbon; $\mu \mathrm{g}$, microgram; BTEX, combined masses of benzene, toluene, ethylbenzene, and total xylenes; m-, meta; p-, para; o-, ortho; MDL, method detection level; nd, not detected; bdl, below detection level; 633269 and 633270 are trip blanks; MTBE, methyl tert-butyl ether; $\mathrm{C}_{11}$, $\mathrm{C}_{13}$, $\mathrm{C}_{15}$, combined masses of undecane, tridecane, and pentadecane; DCA, dichlorethane; TCA, trichloroethane; TCE, trichloroethylene; DCE, dichloroethylene; PCE, perchloroethylene; $\mathrm{DCB}$, dichlorobenzene; $\mathrm{CCl}_{4}$, carbon tetrachloride]

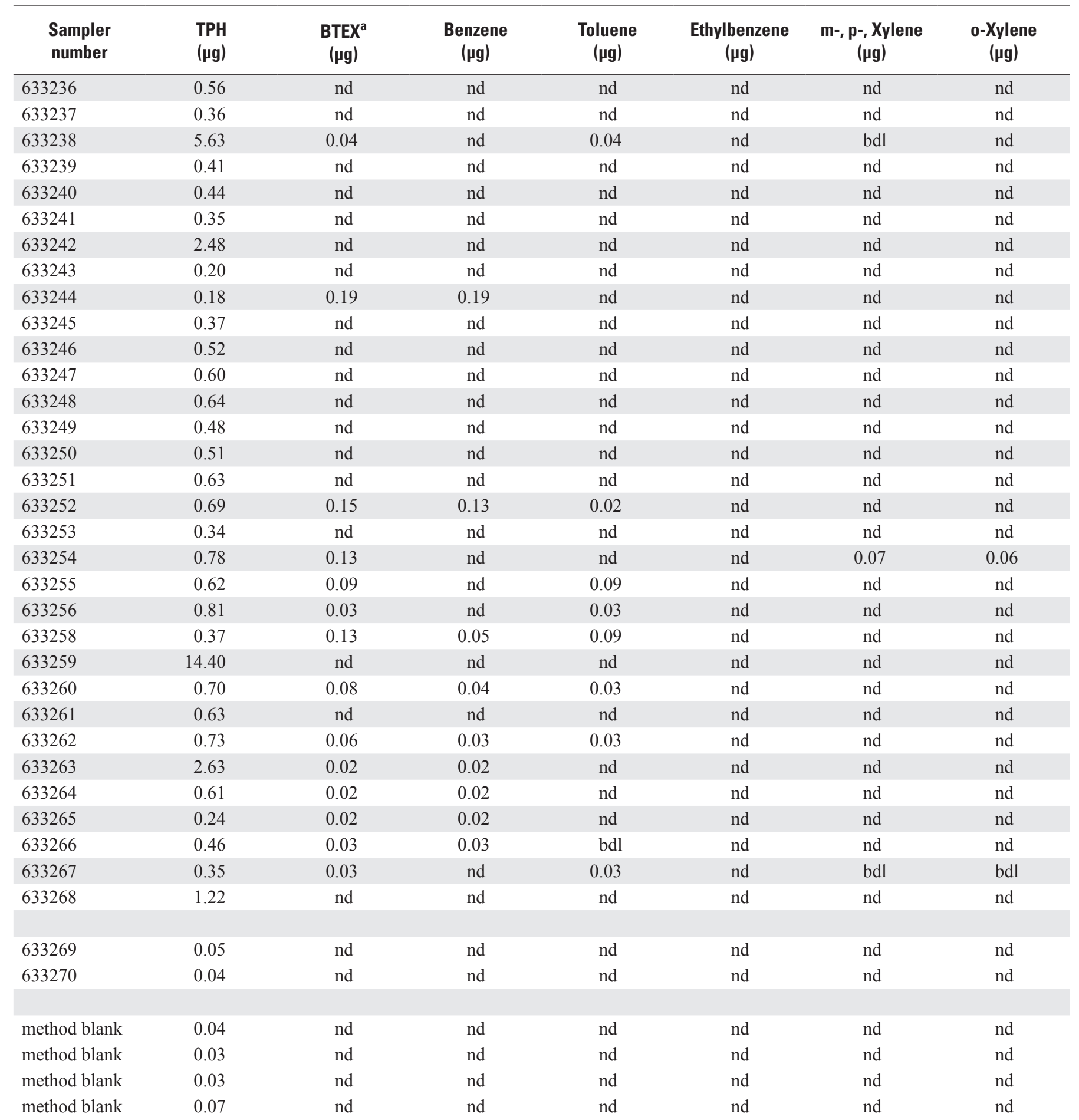


Table 2. Mass of organic compounds detected in soil-gas samplers collected from the Vietnam Armor Training Facility, Fort Gordon, Georgia, June 2010.-Continued

[TPH, total petroleum hydrocarbon; $\mu \mathrm{g}$, microgram; BTEX, combined masses of benzene, toluene, ethylbenzene, and total xylenes; m-, meta; p-, para; o-, ortho; MDL, method detection level; nd, not detected; bdl, below detection level; 633269 and 633270 are trip blanks; MTBE, methyl tert-butyl ether; $\mathrm{C}_{11}, \mathrm{C}_{13}, \mathrm{C}_{15}$, combined masses of undecane, tridecane, and pentadecane; DCA, dichlorethane; TCA, trichloroethane; TCE, trichloroethylene; DCE, dichloroethylene; PCE, perchloroethylene; DCB, dichlorobenzene; $\mathrm{CCl}_{4}$, carbon tetrachloride]

\begin{tabular}{|c|c|c|c|c|}
\hline $\begin{array}{l}\text { Sampler } \\
\text { number }\end{array}$ & $\begin{array}{c}\text { Naphthelene } \\
(\mu g)\end{array}$ & $\begin{array}{c}\text { 2-Methyl- } \\
\text { naphthelene } \\
(\mu \mathrm{g})\end{array}$ & $\begin{array}{c}\text { MTBE } \\
(\mu g)\end{array}$ & $\begin{array}{c}\text { Octane } \\
(\mu \mathrm{g})\end{array}$ \\
\hline MDL & 0.02 & 0.02 & 0.03 & 0.02 \\
\hline 633197 & nd & nd & nd & nd \\
\hline 633198 & nd & nd & nd & nd \\
\hline 633199 & nd & nd & nd & nd \\
\hline 633200 & nd & nd & nd & nd \\
\hline 633201 & nd & nd & nd & nd \\
\hline 633202 & nd & nd & nd & nd \\
\hline 633203 & nd & nd & nd & nd \\
\hline 633204 & nd & nd & nd & nd \\
\hline 633205 & nd & nd & nd & nd \\
\hline 633206 & nd & nd & nd & nd \\
\hline 633207 & nd & nd & nd & nd \\
\hline 633208 & nd & nd & nd & nd \\
\hline 633209 & nd & nd & nd & nd \\
\hline 633210 & nd & nd & nd & nd \\
\hline 633211 & nd & nd & nd & nd \\
\hline 633212 & nd & nd & nd & nd \\
\hline 633213 & bdl & nd & nd & nd \\
\hline 633214 & nd & nd & nd & nd \\
\hline 633215 & nd & nd & nd & nd \\
\hline 633216 & nd & nd & nd & nd \\
\hline 633217 & nd & nd & nd & nd \\
\hline 633218 & nd & nd & nd & nd \\
\hline 633219 & nd & nd & nd & nd \\
\hline 633220 & nd & nd & nd & nd \\
\hline 633221 & nd & nd & nd & nd \\
\hline 633222 & nd & nd & nd & nd \\
\hline 633223 & nd & nd & nd & nd \\
\hline 633224 & nd & nd & nd & nd \\
\hline 633225 & nd & nd & nd & nd \\
\hline 633226 & nd & nd & nd & nd \\
\hline 633227 & nd & nd & nd & nd \\
\hline 633228 & nd & nd & nd & nd \\
\hline 633229 & nd & nd & nd & nd \\
\hline 633230 & nd & nd & nd & nd \\
\hline 633231 & 0.06 & 0.03 & nd & nd \\
\hline 633232 & nd & nd & nd & nd \\
\hline 633233 & nd & nd & nd & nd \\
\hline 633234 & nd & nd & nd & nd \\
\hline 633235 & nd & nd & nd & nd \\
\hline
\end{tabular}


Table 2. Mass of organic compounds detected in soil-gas samplers collected from the Vietnam Armor Training Facility, Fort Gordon, Georgia, June 2010.-Continued

$[\mathrm{TPH}$, total petroleum hydrocarbon; $\mu \mathrm{g}$, microgram; BTEX, combined masses of benzene, toluene, ethylbenzene, and total xylenes; m-, meta; p-, para; o-, ortho; MDL, method detection level; nd, not detected; bdl, below detection level; 633269 and 633270 are trip blanks; MTBE, methyl tert-butyl ether; $\mathrm{C}_{11}, \mathrm{C}_{13}, \mathrm{C}_{15}$, combined masses of undecane, tridecane, and pentadecane; DCA, dichlorethane; TCA, trichloroethane; TCE, trichloroethylene; DCE, dichloroethylene; PCE, perchloroethylene; $\mathrm{DCB}$, dichlorobenzene; $\mathrm{CCl}_{4}$, carbon tetrachloride]

\begin{tabular}{|c|c|c|c|c|}
\hline $\begin{array}{l}\text { Sampler } \\
\text { number }\end{array}$ & $\begin{array}{c}\text { Naphthelene } \\
(\mu \mathrm{g})\end{array}$ & $\begin{array}{c}\text { 2-Methyl- } \\
\text { naphthelene } \\
(\mu \mathrm{g})\end{array}$ & $\begin{array}{l}\text { MTBE } \\
(\mu g)\end{array}$ & $\begin{array}{c}\text { Octane } \\
(\mu \mathrm{g})\end{array}$ \\
\hline 633236 & nd & nd & nd & nd \\
\hline 633237 & nd & nd & nd & nd \\
\hline 633238 & nd & nd & nd & nd \\
\hline 633239 & nd & nd & nd & nd \\
\hline 633240 & nd & nd & nd & nd \\
\hline 633241 & nd & nd & nd & nd \\
\hline 633242 & nd & nd & nd & nd \\
\hline 633243 & nd & nd & nd & nd \\
\hline 633244 & nd & nd & nd & nd \\
\hline 633245 & nd & nd & nd & nd \\
\hline 633246 & nd & nd & nd & nd \\
\hline 633247 & nd & nd & nd & nd \\
\hline 633248 & nd & nd & nd & nd \\
\hline 633249 & nd & nd & nd & nd \\
\hline 633250 & nd & nd & nd & nd \\
\hline 633251 & nd & nd & nd & nd \\
\hline 633252 & nd & nd & nd & nd \\
\hline 633253 & nd & nd & nd & nd \\
\hline 633254 & nd & nd & nd & nd \\
\hline 633255 & nd & bdl & nd & nd \\
\hline 633256 & nd & nd & nd & nd \\
\hline 633258 & nd & nd & nd & nd \\
\hline 633259 & 0.12 & nd & nd & nd \\
\hline 633260 & nd & nd & nd & nd \\
\hline 633261 & nd & nd & nd & nd \\
\hline 633262 & nd & nd & nd & nd \\
\hline 633263 & nd & nd & nd & nd \\
\hline 633264 & nd & nd & nd & nd \\
\hline 633265 & nd & nd & nd & nd \\
\hline 633266 & nd & nd & nd & nd \\
\hline 633267 & nd & nd & nd & nd \\
\hline 633268 & nd & nd & nd & nd \\
\hline 633269 & nd & nd & nd & nd \\
\hline 633270 & nd & nd & nd & nd \\
\hline method blank & nd & nd & nd & nd \\
\hline method blank & nd & nd & nd & nd \\
\hline method blank & nd & nd & nd & nd \\
\hline method blank & nd & nd & nd & nd \\
\hline
\end{tabular}


Table 2. Mass of organic compounds detected in soil-gas samplers collected from the Vietnam Armor Training Facility, Fort Gordon, Georgia, June 2010.-Continued

[TPH, total petroleum hydrocarbon; $\mu \mathrm{g}$, microgram; BTEX, combined masses of benzene, toluene, ethylbenzene, and total xylenes; m-, meta; p-, para; o-, ortho; MDL, method detection level; nd, not detected; bdl, below detection level; 633269 and 633270 are trip blanks; MTBE, methyl tert-butyl ether; $\mathrm{C}_{11}, \mathrm{C}_{13}, \mathrm{C}_{15}$, combined masses of undecane, tridecane, and pentadecane; DCA, dichlorethane; TCA, trichloroethane; TCE, trichloroethylene; DCE, dichloroethylene; PCE, perchloroethylene; $\mathrm{DCB}$, dichlorobenzene; $\mathrm{CCl}_{4}$, carbon tetrachloride]

\begin{tabular}{|c|c|c|c|c|}
\hline $\begin{array}{l}\text { Sampler } \\
\text { number }\end{array}$ & $\begin{array}{c}C_{11^{\prime}} C_{13^{\prime}}, C_{15}^{a} \\
(\mu g)\end{array}$ & $\begin{array}{c}\text { Undecane } \\
(\mu \mathrm{g})\end{array}$ & $\begin{array}{c}\text { Tridecane } \\
(\mu g)\end{array}$ & $\begin{array}{c}\text { Pentadecane } \\
(\mu \mathrm{g})\end{array}$ \\
\hline MDL & & 0.04 & 0.02 & 0.02 \\
\hline 633197 & nd & nd & nd & nd \\
\hline 633198 & nd & nd & nd & nd \\
\hline 633199 & nd & nd & nd & nd \\
\hline 633200 & nd & nd & nd & nd \\
\hline 633201 & nd & nd & nd & nd \\
\hline 633202 & nd & nd & nd & nd \\
\hline 633203 & bdl & nd & nd & bdl \\
\hline 633204 & nd & nd & $\mathrm{nd}$ & nd \\
\hline 633205 & nd & nd & nd & nd \\
\hline 633206 & nd & nd & nd & nd \\
\hline 633207 & nd & nd & nd & nd \\
\hline 633208 & nd & nd & nd & nd \\
\hline 633209 & nd & nd & nd & nd \\
\hline 633210 & nd & nd & nd & nd \\
\hline 633211 & nd & nd & nd & nd \\
\hline 633212 & bdl & nd & bdl & bdl \\
\hline 633213 & bdl & nd & bdl & nd \\
\hline 633214 & nd & nd & nd & nd \\
\hline 633215 & nd & nd & nd & nd \\
\hline 633216 & nd & nd & nd & nd \\
\hline 633217 & nd & nd & nd & nd \\
\hline 633218 & nd & nd & nd & nd \\
\hline 633219 & nd & nd & nd & nd \\
\hline 633220 & bdl & nd & nd & bdl \\
\hline 633221 & nd & nd & nd & nd \\
\hline 633222 & nd & nd & nd & nd \\
\hline 633223 & nd & nd & nd & nd \\
\hline 633224 & nd & nd & nd & nd \\
\hline 633225 & nd & nd & nd & nd \\
\hline 633226 & bdl & bdl & nd & bdl \\
\hline 633227 & nd & nd & nd & nd \\
\hline 633228 & nd & nd & nd & nd \\
\hline 633229 & nd & nd & nd & nd \\
\hline 633230 & nd & nd & nd & nd \\
\hline 633231 & bdl & bdl & nd & nd \\
\hline 633232 & nd & nd & nd & nd \\
\hline 633233 & nd & nd & nd & nd \\
\hline 633234 & nd & nd & nd & nd \\
\hline 633235 & nd & nd & nd & nd \\
\hline
\end{tabular}


Table 2. Mass of organic compounds detected in soil-gas samplers collected from the Vietnam Armor Training Facility, Fort Gordon, Georgia, June 2010._-Continued

[TPH, total petroleum hydrocarbon; $\mu \mathrm{g}$, microgram; BTEX, combined masses of benzene, toluene, ethylbenzene, and total xylenes; m-, meta; p-, para; o-, ortho; MDL, method detection level; nd, not detected; bdl, below detection level; 633269 and 633270 are trip blanks; MTBE, methyl tert-butyl ether; $\mathrm{C}_{11}, \mathrm{C}_{13}, \mathrm{C}_{15}$, combined masses of undecane, tridecane, and pentadecane; DCA, dichlorethane; TCA, trichloroethane; TCE, trichloroethylene; DCE, dichloroethylene; PCE, perchloroethylene; $\mathrm{DCB}$, dichlorobenzene; $\mathrm{CCl}_{4}$, carbon tetrachloride]

\begin{tabular}{|c|c|c|c|c|}
\hline $\begin{array}{l}\text { Sampler } \\
\text { number }\end{array}$ & $\begin{array}{c}C_{11^{\prime}} C_{13^{\prime}} C_{15}{ }^{a} \\
(\mu g)\end{array}$ & $\begin{array}{c}\text { Undecane } \\
(\mu \mathrm{g})\end{array}$ & $\begin{array}{c}\text { Tridecane } \\
(\mu g)\end{array}$ & $\begin{array}{c}\text { Pentadecane } \\
(\mu \mathrm{g})\end{array}$ \\
\hline 633236 & nd & nd & nd & nd \\
\hline 633237 & nd & nd & nd & nd \\
\hline 633238 & bdl & nd & bdl & bdl \\
\hline 633239 & nd & nd & nd & nd \\
\hline 633240 & nd & nd & nd & nd \\
\hline 633241 & nd & nd & nd & nd \\
\hline 633242 & nd & nd & nd & nd \\
\hline 633243 & nd & nd & nd & nd \\
\hline 633244 & bdl & bdl & nd & nd \\
\hline 633245 & nd & nd & nd & nd \\
\hline 633246 & bdl & bdl & nd & nd \\
\hline 633247 & bdl & bdl & nd & nd \\
\hline 633248 & nd & nd & nd & nd \\
\hline 633249 & nd & nd & nd & nd \\
\hline 633250 & nd & nd & nd & nd \\
\hline 633251 & bdl & bdl & nd & nd \\
\hline 633252 & nd & nd & nd & nd \\
\hline 633253 & bdl & bdl & nd & nd \\
\hline 633254 & nd & nd & nd & nd \\
\hline 633255 & bdl & nd & nd & bdl \\
\hline 633256 & nd & nd & nd & nd \\
\hline 633258 & nd & nd & nd & nd \\
\hline 633259 & 0.06 & nd & 0.06 & nd \\
\hline 633260 & nd & nd & nd & nd \\
\hline 633261 & nd & nd & nd & nd \\
\hline 633262 & nd & nd & nd & nd \\
\hline 633263 & nd & nd & nd & nd \\
\hline 633264 & nd & nd & nd & nd \\
\hline 633265 & nd & nd & nd & nd \\
\hline 633266 & nd & nd & nd & nd \\
\hline 633267 & bdl & bdl & nd & bdl \\
\hline 633268 & bdl & bdl & nd & nd \\
\hline 633269 & nd & nd & nd & nd \\
\hline 633270 & nd & nd & nd & nd \\
\hline method blank & nd & nd & nd & nd \\
\hline method blank & nd & nd & nd & nd \\
\hline method blank & nd & nd & nd & nd \\
\hline method blank & nd & nd & nd & nd \\
\hline
\end{tabular}


Table 2. Mass of organic compounds detected in soil-gas samplers collected from the Vietnam Armor Training Facility, Fort Gordon, Georgia, June 2010.-Continued

[TPH, total petroleum hydrocarbon; $\mu \mathrm{g}$, microgram; BTEX, combined masses of benzene, toluene, ethylbenzene, and total xylenes; m-, meta; p-, para; o-, ortho; MDL, method detection level; nd, not detected; bdl, below detection level; 633269 and 633270 are trip blanks; MTBE, methyl tert-butyl ether; $\mathrm{C}_{11}$, $\mathrm{C}_{13}$, $\mathrm{C}_{15}$, combined masses of undecane, tridecane, and pentadecane; DCA, dichlorethane; TCA, trichloroethane; TCE, trichloroethylene; DCE, dichloroethylene; PCE, perchloroethylene; $\mathrm{DCB}$, dichlorobenzene; $\mathrm{CCl}_{4}$, carbon tetrachloride]

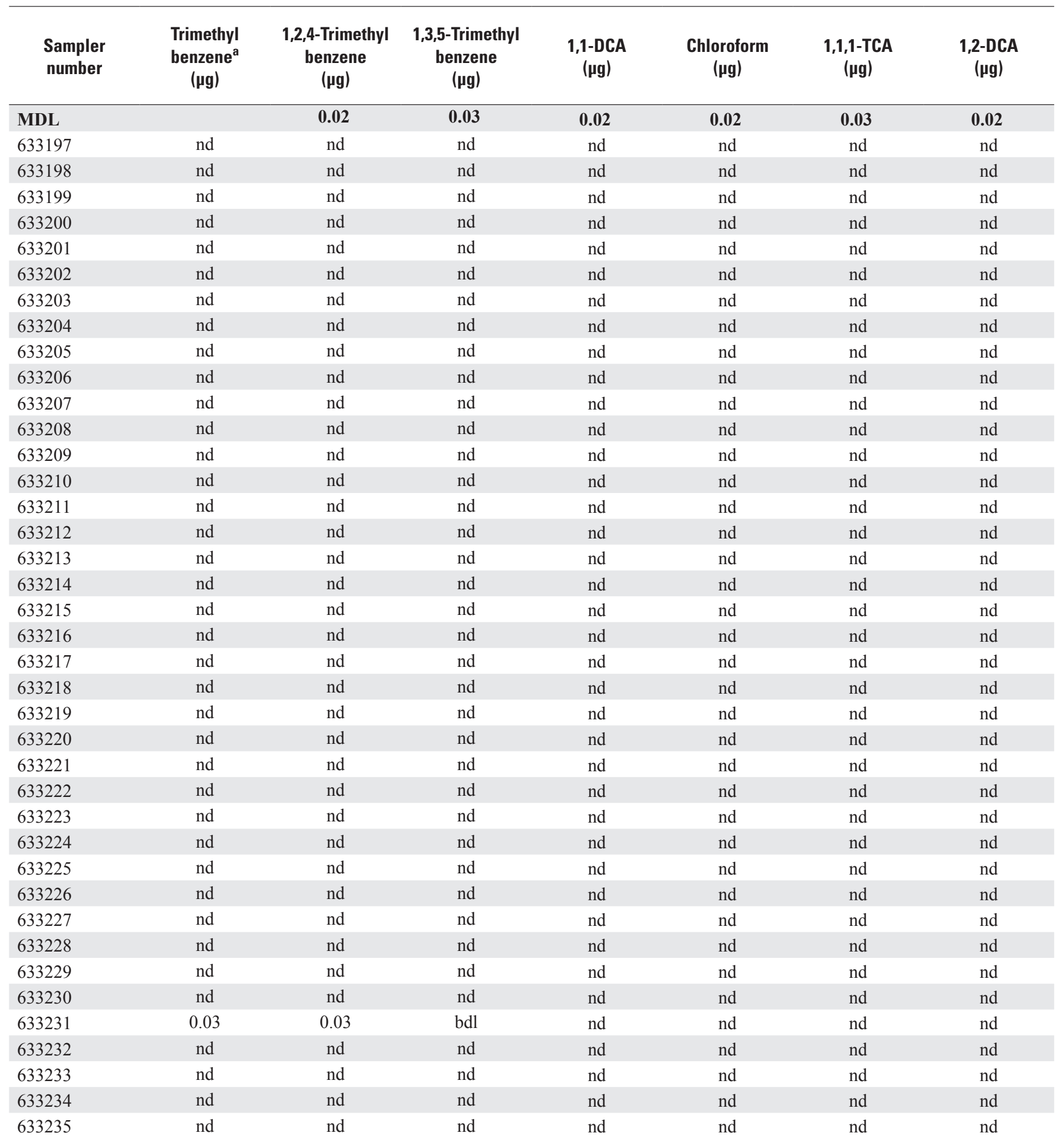


Table 2. Mass of organic compounds detected in soil-gas samplers collected from the Vietnam Armor Training Facility, Fort Gordon, Georgia, June 2010.-Continued

[TPH, total petroleum hydrocarbon; $\mu \mathrm{g}$, microgram; BTEX, combined masses of benzene, toluene, ethylbenzene, and total xylenes; m-, meta; p-, para; o-, ortho; MDL, method detection level; nd, not detected; bdl, below detection level; 633269 and 633270 are trip blanks; MTBE, methyl tert-butyl ether; $\mathrm{C}_{11}$, $\mathrm{C}_{13}$, $\mathrm{C}_{15}$, combined masses of undecane, tridecane, and pentadecane; DCA, dichlorethane; TCA, trichloroethane; TCE, trichloroethylene; DCE, dichloroethylene; PCE, perchloroethylene; $\mathrm{DCB}$, dichlorobenzene; $\mathrm{CCl}_{4}$, carbon tetrachloride]

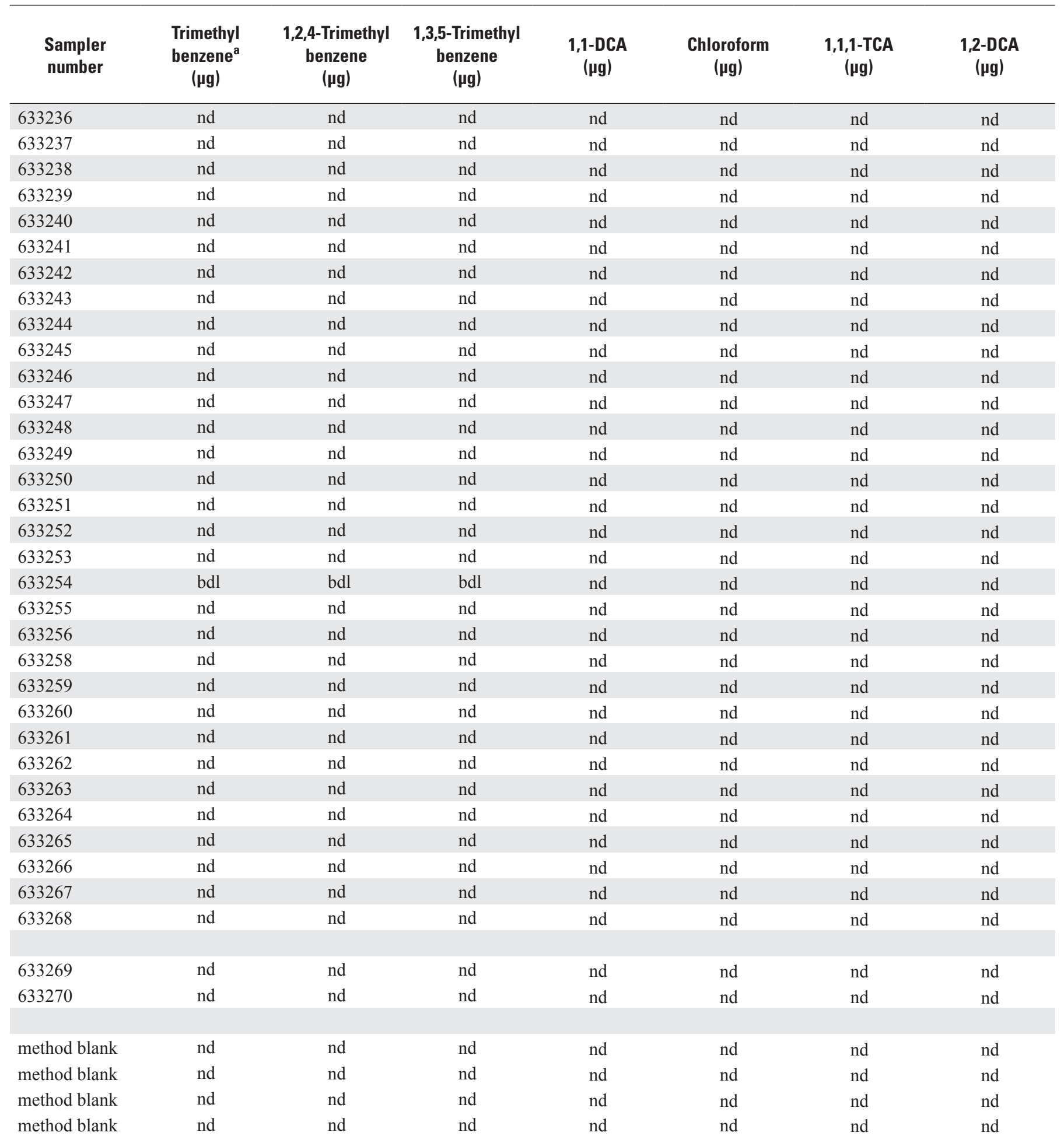


Table 2. Mass of organic compounds detected in soil-gas samplers collected from the Vietnam Armor Training Facility, Fort Gordon, Georgia, June 2010.-Continued

[TPH, total petroleum hydrocarbon; $\mu \mathrm{g}$, microgram; BTEX, combined masses of benzene, toluene, ethylbenzene, and total xylenes; m-, meta; p-, para; o-, ortho; MDL, method detection level; nd, not detected; bdl, below detection level; 633269 and 633270 are trip blanks; MTBE, methyl tertbutyl ether; $\mathrm{C}_{11}, \mathrm{C}_{13}, \mathrm{C}_{15}$, combined masses of undecane, tridecane, and pentadecane; DCA, dichlorethane; TCA, trichloroethane; TCE, trichloroethylene; DCE, dichloroethylene; PCE, perchloroethylene; $\mathrm{DCB}$, dichlorobenzene; $\mathrm{CCl}_{4}$, carbon tetrachloride]

\begin{tabular}{|c|c|c|c|c|c|}
\hline $\begin{array}{l}\text { Sampler } \\
\text { number }\end{array}$ & $\begin{array}{l}\text { TCE } \\
(\mu g)\end{array}$ & $\begin{array}{c}C, t-1,2-D C E^{a} \\
(\mu \mathrm{g})\end{array}$ & $\begin{array}{c}\text { t-1,2-DCE } \\
(\mu \mathrm{g})\end{array}$ & $\begin{array}{c}\text { C-1,2-DCE } \\
(\mu \mathrm{g})\end{array}$ & $\begin{array}{l}\text { PCE } \\
(\mu g)\end{array}$ \\
\hline MDL & 0.02 & & 0.04 & 0.03 & 0.02 \\
\hline 633197 & nd & nd & nd & nd & nd \\
\hline 633198 & nd & nd & nd & nd & nd \\
\hline 633199 & nd & nd & nd & nd & nd \\
\hline 633200 & nd & nd & nd & nd & nd \\
\hline 633201 & nd & nd & nd & nd & nd \\
\hline 633202 & nd & nd & nd & nd & nd \\
\hline 633203 & nd & nd & nd & nd & nd \\
\hline 633204 & nd & nd & nd & nd & nd \\
\hline 633205 & nd & nd & nd & nd & nd \\
\hline 633206 & nd & nd & nd & nd & nd \\
\hline 633207 & nd & nd & nd & nd & nd \\
\hline 633208 & nd & nd & nd & nd & nd \\
\hline 633209 & nd & nd & nd & nd & nd \\
\hline 633210 & nd & nd & nd & nd & nd \\
\hline 633211 & nd & nd & nd & nd & nd \\
\hline 633212 & nd & nd & nd & nd & nd \\
\hline 633213 & nd & nd & nd & nd & nd \\
\hline 633214 & nd & nd & nd & nd & nd \\
\hline 633215 & nd & nd & nd & nd & nd \\
\hline 633216 & nd & nd & nd & nd & nd \\
\hline 633217 & nd & nd & nd & nd & nd \\
\hline 633218 & nd & nd & nd & nd & nd \\
\hline 633219 & nd & nd & nd & nd & nd \\
\hline 633220 & nd & nd & nd & nd & nd \\
\hline 633221 & nd & nd & nd & nd & nd \\
\hline 633222 & nd & nd & nd & nd & nd \\
\hline 633223 & nd & nd & nd & nd & nd \\
\hline 633224 & nd & nd & nd & nd & nd \\
\hline 633225 & nd & nd & nd & nd & nd \\
\hline 633226 & nd & nd & nd & nd & nd \\
\hline 633227 & nd & nd & nd & nd & nd \\
\hline 633228 & nd & nd & nd & nd & nd \\
\hline 633229 & nd & nd & nd & nd & nd \\
\hline 633230 & nd & nd & nd & nd & nd \\
\hline 633231 & nd & nd & nd & nd & nd \\
\hline 633232 & nd & nd & nd & nd & nd \\
\hline 633233 & nd & nd & nd & nd & nd \\
\hline 633234 & nd & nd & nd & nd & nd \\
\hline 633235 & nd & nd & nd & nd & nd \\
\hline
\end{tabular}


Table 2. Mass of organic compounds detected in soil-gas samplers collected from the Vietnam Armor Training Facility, Fort Gordon, Georgia, June 2010.-Continued

[TPH, total petroleum hydrocarbon; $\mu \mathrm{g}$, microgram; BTEX, combined masses of benzene, toluene, ethylbenzene, and total xylenes; m-, meta; p-, para; o-, ortho; MDL, method detection level; nd, not detected; bdl, below detection level; 633269 and 633270 are trip blanks; MTBE, methyl tertbutyl ether; $\mathrm{C}_{11}, \mathrm{C}_{13}, \mathrm{C}_{15}$, combined masses of undecane, tridecane, and pentadecane; DCA, dichlorethane; TCA, trichloroethane; TCE, trichloroethylene; DCE, dichloroethylene; PCE, perchloroethylene; $\mathrm{DCB}$, dichlorobenzene; $\mathrm{CCl}_{4}$, carbon tetrachloride]

\begin{tabular}{|c|c|c|c|c|c|}
\hline $\begin{array}{l}\text { Sampler } \\
\text { number }\end{array}$ & $\begin{array}{l}\text { TCE } \\
(\mu g)\end{array}$ & $\begin{array}{c}C, t-1,2-D C E^{a} \\
(\mu \mathrm{g})\end{array}$ & $\begin{array}{c}\text { t-1,2-DCE } \\
(\mu \mathrm{g})\end{array}$ & $\begin{array}{c}\text { C-1,2-DCE } \\
(\mu \mathrm{g})\end{array}$ & $\begin{array}{l}\text { PCE } \\
(\mu \mathrm{g})\end{array}$ \\
\hline 633236 & nd & nd & nd & nd & nd \\
\hline 633237 & nd & nd & nd & nd & nd \\
\hline 633238 & nd & nd & nd & nd & nd \\
\hline 633239 & nd & nd & nd & nd & nd \\
\hline 633240 & nd & nd & nd & nd & nd \\
\hline 633241 & nd & nd & nd & nd & nd \\
\hline 633242 & nd & nd & nd & nd & nd \\
\hline 633243 & nd & nd & nd & nd & nd \\
\hline 633244 & nd & bdl & nd & bdl & nd \\
\hline 633245 & nd & nd & nd & nd & nd \\
\hline 633246 & nd & nd & nd & nd & nd \\
\hline 633247 & nd & nd & nd & nd & nd \\
\hline 633248 & nd & nd & nd & nd & nd \\
\hline 633249 & nd & nd & nd & nd & nd \\
\hline 633250 & nd & nd & nd & nd & nd \\
\hline 633251 & nd & nd & nd & nd & nd \\
\hline 633252 & nd & nd & nd & nd & nd \\
\hline 633253 & nd & nd & nd & nd & nd \\
\hline 633254 & nd & nd & nd & nd & 0.07 \\
\hline 633255 & nd & nd & nd & nd & nd \\
\hline 633256 & nd & nd & nd & nd & nd \\
\hline 633258 & nd & nd & nd & nd & nd \\
\hline 633259 & nd & nd & nd & nd & nd \\
\hline 633260 & nd & nd & nd & nd & nd \\
\hline 633261 & nd & nd & nd & nd & nd \\
\hline 633262 & nd & nd & nd & nd & nd \\
\hline 633263 & nd & nd & nd & nd & nd \\
\hline 633264 & nd & nd & nd & nd & nd \\
\hline 633265 & nd & nd & nd & nd & nd \\
\hline 633266 & nd & nd & nd & nd & nd \\
\hline 633267 & nd & nd & nd & nd & nd \\
\hline 633268 & nd & nd & nd & nd & nd \\
\hline 633269 & nd & nd & nd & nd & nd \\
\hline 633270 & nd & nd & nd & nd & nd \\
\hline method blank & nd & nd & nd & nd & nd \\
\hline method blank & nd & nd & nd & nd & nd \\
\hline method blank & nd & nd & nd & nd & nd \\
\hline method blank & nd & nd & nd & nd & nd \\
\hline
\end{tabular}


Table 2. Mass of organic compounds detected in soil-gas samplers collected from the Vietnam Armor Training Facility, Fort Gordon, Georgia, June 2010.-Continued

[TPH, total petroleum hydrocarbon; $\mu \mathrm{g}$, microgram; BTEX, combined masses of benzene, toluene, ethylbenzene, and total xylenes; m-, meta; p-, para; o-, ortho; MDL, method detection level; nd, not detected; bdl, below detection level; 633269 and 633270 are trip blanks; MTBE, methyl tert-butyl ether; $\mathrm{C}_{11}$, $\mathrm{C}_{13}$, $\mathrm{C}_{15}$, combined masses of undecane, tridecane, and pentadecane; DCA, dichlorethane; TCA, trichloroethane; TCE, trichloroethylene; DCE, dichloroethylene; PCE, perchloroethylene; $\mathrm{DCB}$, dichlorobenzene; $\mathrm{CCl}_{4}$, carbon tetrachloride]

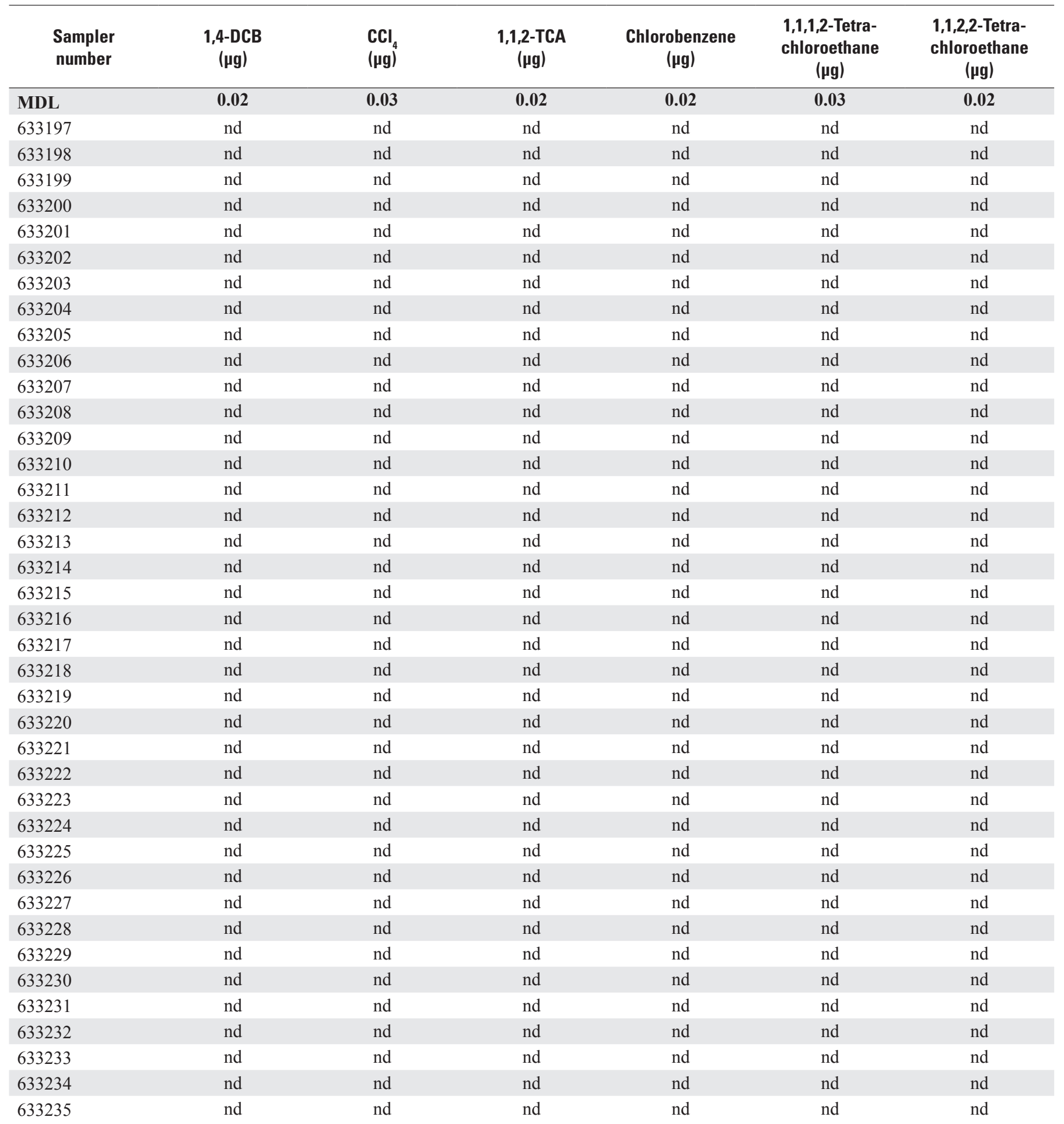


Table 2. Mass of organic compounds detected in soil-gas samplers collected from the Vietnam Armor Training Facility, Fort Gordon, Georgia, June 2010.-Continued

[TPH, total petroleum hydrocarbon; $\mu \mathrm{g}$, microgram; BTEX, combined masses of benzene, toluene, ethylbenzene, and total xylenes; m-, meta; p-, para; o-, ortho; MDL, method detection level; nd, not detected; bdl, below detection level; 633269 and 633270 are trip blanks; MTBE, methyl tert-butyl ether; $\mathrm{C}_{11}$, $\mathrm{C}_{13}$, $\mathrm{C}_{15}$, combined masses of undecane, tridecane, and pentadecane; DCA, dichlorethane; TCA, trichloroethane; TCE, trichloroethylene; DCE, dichloroethylene; PCE, perchloroethylene; $\mathrm{DCB}$, dichlorobenzene; $\mathrm{CCl}_{4}$, carbon tetrachloride]

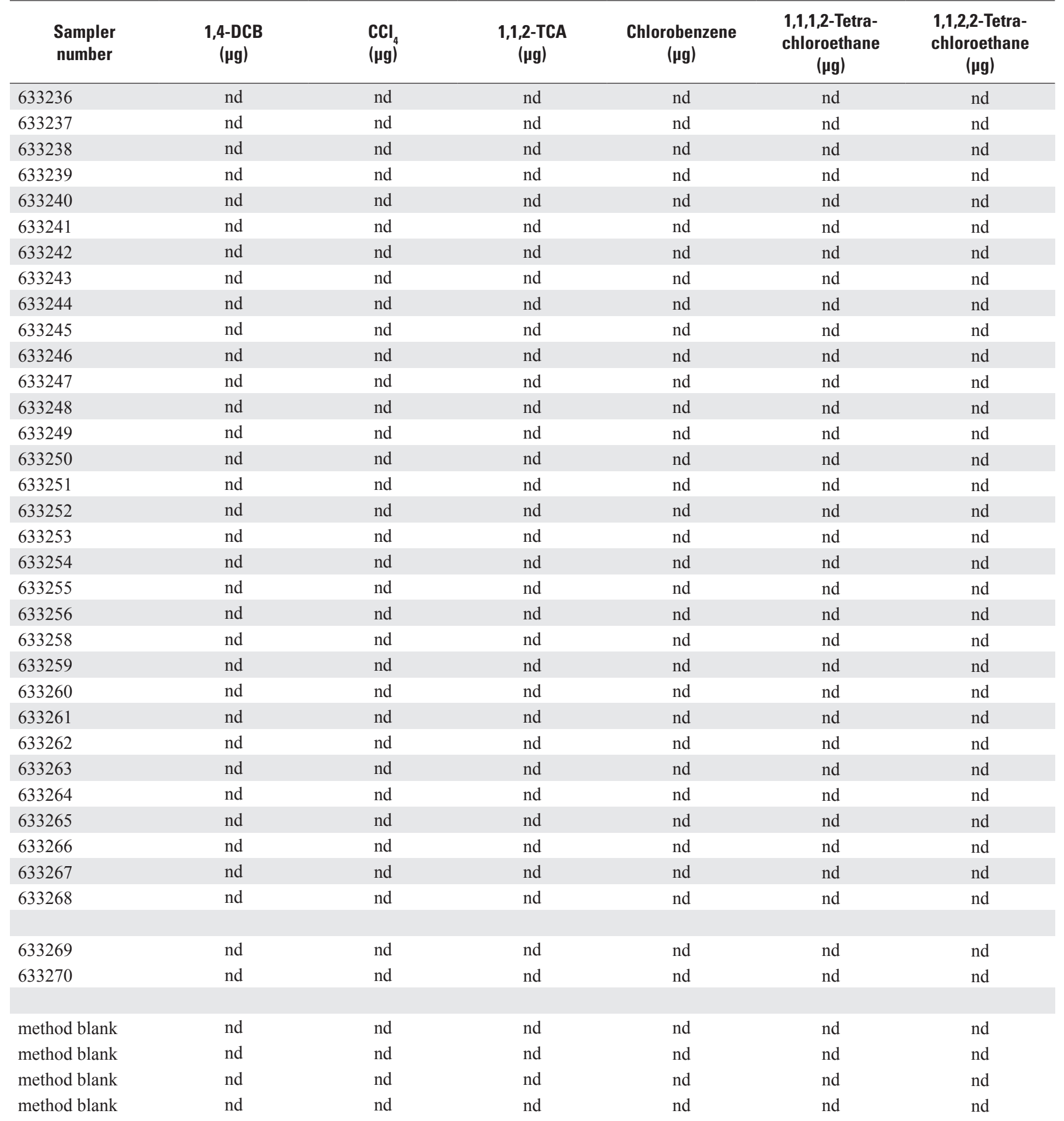


Table 2. Mass of organic compounds detected in soil-gas samplers collected from the Vietnam Armor Training Facility, Fort Gordon, Georgia, June 2010.-Continued

[TPH, total petroleum hydrocarbon; $\mu \mathrm{g}$, microgram; BTEX, combined masses of benzene, toluene, ethylbenzene, and total xylenes; m-, meta; p-, para; o-, ortho; MDL, method detection level; nd, not detected; bdl, below detection level; 633269 and 633270 are trip blanks; MTBE, methyl tert-butyl ether; $\mathrm{C}_{11}, \mathrm{C}_{13}, \mathrm{C}_{15}$, combined masses of undecane, tridecane, and pentadecane; DCA, dichlorethane; TCA, trichloroethane; TCE, trichloroethylene; DCE, dichloroethylene; PCE, perchloroethylene; $\mathrm{DCB}$, dichlorobenzene; $\mathrm{CCl}_{4}$, carbon tetrachloride]

\begin{tabular}{|c|c|c|}
\hline $\begin{array}{l}\text { Sampler } \\
\text { number }\end{array}$ & $\begin{array}{c}\text { 1,3-Dichlorobenzene } \\
\text { ( } \mu \mathrm{g})\end{array}$ & $\begin{array}{l}\text { 1,2-Dichlorobenzene } \\
(\mu \mathrm{g})\end{array}$ \\
\hline MDL & 0.02 & 0.02 \\
\hline 633197 & nd & nd \\
\hline 633198 & nd & nd \\
\hline 633199 & nd & nd \\
\hline 633200 & nd & nd \\
\hline 633201 & nd & nd \\
\hline 633202 & nd & nd \\
\hline 633203 & nd & nd \\
\hline 633204 & nd & nd \\
\hline 633205 & nd & nd \\
\hline 633206 & nd & nd \\
\hline 633207 & nd & nd \\
\hline 633208 & nd & nd \\
\hline 633209 & nd & nd \\
\hline 633210 & nd & nd \\
\hline 633211 & nd & nd \\
\hline 633212 & nd & nd \\
\hline 633213 & nd & nd \\
\hline 633214 & nd & nd \\
\hline 633215 & nd & nd \\
\hline 633216 & nd & nd \\
\hline 633217 & nd & nd \\
\hline 633218 & nd & nd \\
\hline 633219 & nd & nd \\
\hline 633220 & nd & nd \\
\hline 633221 & nd & nd \\
\hline 633222 & nd & nd \\
\hline 633223 & nd & nd \\
\hline 633224 & nd & nd \\
\hline 633225 & nd & nd \\
\hline 633226 & nd & nd \\
\hline 633227 & nd & nd \\
\hline 633228 & nd & nd \\
\hline 633229 & nd & nd \\
\hline 633230 & nd & nd \\
\hline 633231 & nd & nd \\
\hline 633232 & nd & nd \\
\hline 633233 & nd & nd \\
\hline 633234 & nd & nd \\
\hline 633235 & nd & nd \\
\hline
\end{tabular}


Table 2. Mass of organic compounds detected in soil-gas samplers collected from the Vietnam Armor Training Facility, Fort Gordon, Georgia, June 2010._Continued

$[\mathrm{TPH}$, total petroleum hydrocarbon; $\mu \mathrm{g}$, microgram; BTEX, combined masses of benzene, toluene, ethylbenzene, and total xylenes; m-, meta; p-, para; o-, ortho; MDL, method detection level; nd, not detected; bdl, below detection level; 633269 and 633270 are trip blanks; MTBE, methyl tert-butyl ether; $\mathrm{C}_{11}, \mathrm{C}_{13}, \mathrm{C}_{15}$, combined masses of undecane, tridecane, and pentadecane; DCA, dichlorethane; TCA, trichloroethane; TCE, trichloroethylene; DCE, dichloroethylene; PCE, perchloroethylene; $\mathrm{DCB}$, dichlorobenzene; $\mathrm{CCl}_{4}$, carbon tetrachloride]

\begin{tabular}{|c|c|c|}
\hline $\begin{array}{l}\text { Sampler } \\
\text { number }\end{array}$ & $\begin{array}{c}\text { 1,3-Dichlorobenzene } \\
\text { ( } \mu \mathrm{g})\end{array}$ & $\begin{array}{c}\text { 1,2-Dichlorobenzene } \\
(\mu \mathrm{g})\end{array}$ \\
\hline 633236 & nd & nd \\
\hline 633237 & nd & nd \\
\hline 633238 & nd & nd \\
\hline 633239 & nd & nd \\
\hline 633240 & nd & nd \\
\hline 633241 & nd & nd \\
\hline 633242 & nd & nd \\
\hline 633243 & nd & nd \\
\hline 633244 & nd & nd \\
\hline 633245 & nd & nd \\
\hline 633246 & nd & nd \\
\hline 633247 & nd & nd \\
\hline 633248 & nd & nd \\
\hline 633249 & nd & nd \\
\hline 633250 & nd & nd \\
\hline 633251 & nd & nd \\
\hline 633252 & nd & nd \\
\hline 633253 & nd & nd \\
\hline 633254 & nd & nd \\
\hline 633255 & nd & nd \\
\hline 633256 & nd & nd \\
\hline 633258 & nd & nd \\
\hline 633259 & nd & nd \\
\hline 633260 & nd & nd \\
\hline 633261 & nd & nd \\
\hline 633262 & nd & nd \\
\hline 633263 & nd & nd \\
\hline 633264 & nd & nd \\
\hline 633265 & nd & nd \\
\hline 633266 & nd & nd \\
\hline 633267 & nd & nd \\
\hline 633268 & nd & nd \\
\hline 633269 & nd & nd \\
\hline 633270 & nd & nd \\
\hline method blank & nd & nd \\
\hline method blank & nd & nd \\
\hline method blank & nd & nd \\
\hline method blank & nd & nd \\
\hline
\end{tabular}

${ }^{\mathrm{a}}$ Combined concentration for two or more compounds with no method detection level provided by laboratory. 
Table 3: Mass of organic compounds detected in soil-gas samplers, Vietnam Armor Training Facility, Fort Gordon, Georgia, July 2011.

[TPH, total petroleum hydrocarbons; $\mu \mathrm{g}$, micrograms; BTEX, summation of benzene, toluene, ethylbenzene, and total xylene; m, meta; $\mathrm{p}$, para; o, ortho; MDL, method detection level; nd, not detected; bdl, below detection level; 662143, 662144, and 662145 are trip blanks; MTBE, methyl tert-butyl ether; $\mathrm{C}_{11}, \mathrm{C}_{13}, \mathrm{C}_{15}$, combined masses of undecane, tridecane, and pentadecane; DCA dichloroethane; TCA, trchloroethane; TCE, trichloroethylene; PCE, perchloroethylene; $\mathrm{DCE}$, dichloroethylene; $\mathrm{CCL}_{4}$, carbon tetrachloride; $\mathrm{DCB}$, dichlorobenzene]

\begin{tabular}{|c|c|c|c|c|c|c|c|}
\hline $\begin{array}{l}\text { Sampler } \\
\text { number }\end{array}$ & $\begin{array}{l}\text { TPH } \\
(\mu g)\end{array}$ & $\begin{array}{c}\text { BTEXa } \\
(\mu \mathrm{g})\end{array}$ & $\begin{array}{c}\text { Benzene } \\
(\mu \mathrm{g})\end{array}$ & $\begin{array}{c}\text { Toluene } \\
(\mu \mathrm{g})\end{array}$ & $\begin{array}{c}\text { Ethlybenzene } \\
(\mu \mathrm{g})\end{array}$ & $\begin{array}{c}\text { m-,p-Xylene } \\
(\mu g)\end{array}$ & $\begin{array}{c}\text { o-Xylene } \\
(\mu \mathrm{g})\end{array}$ \\
\hline MDL= & 0.02 & & 0.01 & 0.01 & 0.02 & 0.02 & 0.01 \\
\hline 662104 & 0.33 & 0.02 & 0.02 & nd & nd & nd & nd \\
\hline 662105 & 0.97 & 0.01 & 0.01 & nd & nd & nd & nd \\
\hline 662108 & 0.24 & 0.02 & bdl & 0.02 & nd & nd & nd \\
\hline 662109 & 0.74 & 0.01 & 0.01 & nd & bdl & nd & bdl \\
\hline 662110 & 66.36 & 0.42 & bdl & 0.42 & nd & bdl & nd \\
\hline 662111 & 4.72 & 0.08 & 0.06 & 0.01 & nd & nd & nd \\
\hline 662116 & 0.44 & bdl & bdl & bdl & nd & bdl & nd \\
\hline 662117 & 2.99 & 0.02 & 0.02 & bdl & nd & nd & nd \\
\hline 662118 & 0.24 & bdl & bdl & nd & bdl & nd & nd \\
\hline 662119 & 0.42 & bdl & bdl & nd & nd & nd & nd \\
\hline 662120 & 0.44 & 0.02 & 0.02 & bdl & nd & nd & nd \\
\hline 662121 & 56.82 & 0.40 & 0.01 & 0.39 & nd & nd & nd \\
\hline 662122 & 0.68 & bdl & bdl & nd & nd & nd & nd \\
\hline 662123 & 0.30 & nd & nd & nd & nd & nd & nd \\
\hline 662124 & 0.21 & nd & nd & nd & nd & nd & nd \\
\hline 662130 & 0.75 & bdl & bdl & nd & nd & nd & nd \\
\hline
\end{tabular}




\section{Assessment of Groundwater, Soil-Gas, and Soil Contamination at the Vietnam Armor Training Facility}

Table 3: Mass of organic compounds detected in soil-gas samplers, Vietnam Armor Training Facility, Fort Gordon, Georgia, July 2011.-Continued

[TPH, total petroleum hydrocarbons; $\mu \mathrm{g}$, micrograms; BTEX, summation of benzene, toluene, ethylbenzene, and total xylene; m, meta; $\mathrm{p}$, para; $\mathrm{o}$, ortho; MDL,method detection level; nd, not detected; bdl, below detection level; 662143, 662144, and 662145 are trip blanks; MTBE, methyl tert-butyl ether; $\mathrm{C}_{11}, \mathrm{C}_{13}, \mathrm{C}_{15}$, combined masses of undecane, tridecane, and pentadecane; DCA dichloroethane; TCA, trchloroethane; TCE, trichloroethylene; PCE, perchloroethylene; DCE, dichloroethylene; $\mathrm{CCL}_{4}$, carbon tetrachloride; $\mathrm{DCB}$, dichlorobenzene]

\begin{tabular}{|c|c|c|c|c|c|c|c|}
\hline $\begin{array}{l}\text { Sampler } \\
\text { number }\end{array}$ & $\begin{array}{l}\text { TPH } \\
(\mu g)\end{array}$ & $\begin{array}{c}\text { BTEXa } \\
(\mu \mathrm{g})\end{array}$ & $\begin{array}{c}\text { Benzene } \\
(\mu g)\end{array}$ & $\begin{array}{c}\text { Toluene } \\
\text { ( } \mu g)\end{array}$ & $\begin{array}{c}\text { Ethlybenzene } \\
\text { ( } \mu \mathrm{g})\end{array}$ & $\begin{array}{c}\text { m-,p-Xylene } \\
(\mu g)\end{array}$ & $\begin{array}{c}\text { o-Xylene } \\
(\mu \mathrm{g})\end{array}$ \\
\hline MDL= & 0.02 & & 0.01 & 0.01 & 0.02 & 0.02 & 0.01 \\
\hline 662132 & 21.45 & bdl & bdl & nd & bdl & bdl & bdl \\
\hline 662133 & 47.27 & 0.14 & 0.01 & 0.07 & bdl & 0.03 & 0.02 \\
\hline 662143 & 0.09 & bdl & bdl & nd & nd & nd & nd \\
\hline 662144 & 0.13 & bdl & bdl & nd & nd & nd & nd \\
\hline 662145 & 0.10 & nd & nd & nd & nd & nd & nd \\
\hline Maximum & 66.36 & 0.42 & 0.07 & 0.42 & 0.01 & 0.03 & 0.02 \\
\hline $\begin{array}{l}\text { Standard } \\
\text { deviation }\end{array}$ & 17.32 & 0.10 & 0.02 & 0.10 & 0.00 & 0.01 & 0.00 \\
\hline Mean & 7.72 & 0.04 & 0.01 & 0.03 & 0.00 & 0.00 & 0.00 \\
\hline
\end{tabular}


Table 3: Mass of organic compounds detected in soil-gas samplers, Vietnam Armor Training Facility, Fort Gordon, Georgia, July 2011.-Continued

$[\mathrm{TPH}$, total petroleum hydrocarbons; $\mu \mathrm{g}$, micrograms; BTEX, summation of benzene, toluene, ethylbenzene, and total xylene; m, meta; p, para; o, ortho; MDL,method detection level; nd, not detected; bdl, below detection level; 662143, 662144, and 662145 are trip blanks; MTBE, methyl tert-butyl ether; $\mathrm{C}_{11}, \mathrm{C}_{13}, \mathrm{C}_{15}$, combined masses of undecane, tridecane, and pentadecane; DCA dichloroethane; TCA, trchloroethane; TCE, trichloroethylene; PCE, perchloroethylene; DCE, dichloroethylene; $\mathrm{CCL}_{4}$, carbon tetrachloride; $\mathrm{DCB}$, dichlorobenzene]

\begin{tabular}{|c|c|c|c|c|}
\hline $\begin{array}{l}\text { Sampler } \\
\text { number }\end{array}$ & $\begin{array}{c}\text { Naphthalene } \\
(\mu \mathrm{g})\end{array}$ & $\begin{array}{l}\text { 2-Methyl-Naphthalene } \\
(\mu \mathrm{g})\end{array}$ & $\begin{array}{c}\text { MTBE } \\
(\mu g)\end{array}$ & $\begin{array}{c}\text { Octane } \\
(\mu g)\end{array}$ \\
\hline MDL= & 0.01 & 0.01 & 0.03 & 0.02 \\
\hline 662103 & nd & nd & bdl & nd \\
\hline 662104 & nd & nd & nd & bdl \\
\hline 662105 & nd & nd & nd & nd \\
\hline 662106 & nd & nd & nd & nd \\
\hline 662107 & nd & nd & nd & nd \\
\hline 662108 & nd & nd & nd & nd \\
\hline 662109 & nd & nd & bdl & nd \\
\hline 662110 & nd & nd & nd & nd \\
\hline 662111 & nd & nd & nd & nd \\
\hline 662112 & nd & nd & nd & nd \\
\hline 662113 & nd & bdl & nd & nd \\
\hline 662115 & nd & nd & nd & nd \\
\hline 662116 & nd & nd & nd & nd \\
\hline 662117 & nd & bdl & nd & nd \\
\hline 662118 & nd & nd & nd & nd \\
\hline 662119 & nd & nd & nd & nd \\
\hline 662120 & nd & nd & nd & nd \\
\hline 662121 & nd & nd & nd & nd \\
\hline 662122 & nd & nd & nd & nd \\
\hline 662123 & nd & nd & nd & nd \\
\hline 662124 & nd & nd & nd & nd \\
\hline 662125 & nd & nd & nd & nd \\
\hline 662126 & nd & nd & nd & nd \\
\hline 662127 & nd & nd & nd & nd \\
\hline 662128 & nd & bdl & nd & nd \\
\hline 662129 & nd & nd & nd & nd \\
\hline 662130 & nd & nd & nd & nd \\
\hline 662131 & nd & nd & nd & nd \\
\hline 662132 & 0.01 & 0.01 & bdl & nd \\
\hline 662133 & 0.02 & 0.02 & nd & 0.04 \\
\hline 662146 & nd & bdl & nd & nd \\
\hline
\end{tabular}


Table 3: Mass of organic compounds detected in soil-gas samplers, Vietnam Armor Training Facility, Fort Gordon, Georgia, July 2011.-Continued

[TPH, total petroleum hydrocarbons; $\mu \mathrm{g}$, micrograms; BTEX, summation of benzene, toluene, ethylbenzene, and total xylene; m, meta; p, para; o, ortho; MDL,method detection level; nd, not detected; bdl, below detection level; 662143, 662144, and 662145 are trip blanks; MTBE, methyl tert-butyl ether; $\mathrm{C}_{11}, \mathrm{C}_{13}, \mathrm{C}_{15}$, combined masses of undecane, tridecane, and pentadecane; DCA dichloroethane; TCA, trchloroethane; TCE, trichloroethylene; PCE, perchloroethylene; DCE, dichloroethylene; $\mathrm{CCL}_{4}$, carbon tetrachloride; DCB, dichlorobenzene]

\begin{tabular}{lcccc}
\hline $\begin{array}{l}\text { Sampler } \\
\text { number }\end{array}$ & $\begin{array}{c}\text { Naphthalene } \\
(\boldsymbol{\mu g})\end{array}$ & $\begin{array}{c}\text { 2-Methyl-Naphthalene } \\
(\boldsymbol{\mu g})\end{array}$ & $\begin{array}{c}\text { MTBE } \\
(\boldsymbol{\mu} \mathbf{g})\end{array}$ & $\begin{array}{c}\text { Octane } \\
(\boldsymbol{\mu g})\end{array}$ \\
\hline MDL= & $\mathbf{0 . 0 1}$ & $\mathbf{0 . 0 1}$ & $\mathbf{0 . 0 3}$ & $\mathbf{0 . 0 2}$ \\
\hline 662143 & nd & nd & nd & nd \\
662144 & nd & nd & nd & nd \\
662145 & nd & nd & nd & nd \\
method blank & nd & bdl & nd & nd \\
method blank & nd & nd & nd & nd \\
& & & & 0.04 \\
Maximum & 0.02 & 0.02 & 0.00 & 0.01 \\
Standard & & & 0.00 & 0.00
\end{tabular}

Table 3: Mass of organic compounds detected in soil-gas samplers, Vietnam Armor Training Facility, Fort Gordon, Georgia, July 2011.-Continued

[TPH, total petroleum hydrocarbons; $\mu \mathrm{g}$, micrograms; BTEX, summation of benzene, toluene, ethylbenzene, and total xylene; m, meta; p, para; o, ortho; MDL, method detection level; nd, not detected; bdl, below detection level; 662143, 662144, and 662145 are trip blanks; MTBE, methyl tert-butyl ether; $\mathrm{C}_{11}, \mathrm{C}_{13}, \mathrm{C}_{15}$, combined masses of undecane, tridecane, and pentadecane; DCA dichloroethane; TCA, trchloroethane; TCE, trichloroethylene; PCE, perchloroethylene; DCE, dichloroethylene; $\mathrm{CCL}_{4}$, carbon tetrachloride; $\mathrm{DCB}$, dichlorobenzene]

\begin{tabular}{|c|c|c|c|c|}
\hline $\begin{array}{l}\text { Sampler } \\
\text { number }\end{array}$ & $\begin{array}{c}C_{11^{\prime}}, C_{13^{\prime}} C_{15} \\
(\mu g)\end{array}$ & $\begin{array}{c}\text { Undecane } \\
\text { ( } \mu g)\end{array}$ & $\begin{array}{c}\text { Tridecane } \\
(\mu g)\end{array}$ & $\begin{array}{c}\text { Pentadecane } \\
(\mu \mathrm{g})\end{array}$ \\
\hline MDL= & & 0.01 & 0.01 & 0.01 \\
\hline 662103 & nd & nd & nd & nd \\
\hline 662104 & bdl & nd & bdl & nd \\
\hline 662105 & bdl & nd & nd & bdl \\
\hline 662106 & bdl & bdl & nd & bdl \\
\hline 662107 & 0.20 & 0.20 & nd & nd \\
\hline 662108 & bdl & bdl & nd & bdl \\
\hline 662109 & bdl & nd & bdl & nd \\
\hline 662110 & nd & nd & nd & nd \\
\hline 662111 & bdl & nd & bdl & bdl \\
\hline 662112 & bdl & nd & bdl & bdl \\
\hline 662113 & bdl & bdl & nd & bdl \\
\hline 662115 & bdl & bdl & bdl & bdl \\
\hline 662116 & bdl & bdl & nd & bdl \\
\hline 662117 & 0.24 & 0.24 & bdl & bdl \\
\hline 662118 & bdl & nd & bdl & bdl \\
\hline 662119 & bdl & nd & nd & bdl \\
\hline
\end{tabular}


Table 3: Mass of organic compounds detected in soil-gas samplers, Vietnam Armor Training Facility, Fort Gordon, Georgia, July 2011.-Continued

[TPH, total petroleum hydrocarbons; $\mu \mathrm{g}$, micrograms; BTEX, summation of benzene, toluene, ethylbenzene, and total xylene; m, meta; p, para; o, ortho; MDL, method detection level; nd, not detected; bdl, below detection level; 662143, 662144, and 662145 are trip blanks; MTBE, methyl tert-butyl ether; $\mathrm{C}_{11}, \mathrm{C}_{13}, \mathrm{C}_{15}$, combined masses of undecane, tridecane, and pentadecane; DCA dichloroethane; TCA, trchloroethane; TCE, trichloroethylene; PCE, perchloroethylene; DCE, dichloroethylene; $\mathrm{CCL}_{4}$, carbon tetrachloride; $\mathrm{DCB}$, dichlorobenzene]

\begin{tabular}{|c|c|c|c|c|}
\hline $\begin{array}{l}\text { Sampler } \\
\text { number }\end{array}$ & $\begin{array}{c}C_{11^{\prime}}, C_{13^{\prime}} C_{15} \\
(\mu g)\end{array}$ & $\begin{array}{c}\text { Undecane } \\
(\mu \mathrm{g})\end{array}$ & $\begin{array}{c}\text { Tridecane } \\
(\mu \mathrm{g})\end{array}$ & $\begin{array}{c}\text { Pentadecane } \\
(\mu \mathrm{g})\end{array}$ \\
\hline MDL= & & 0.01 & 0.01 & 0.01 \\
\hline 662120 & 0.01 & 0.01 & bdl & bdl \\
\hline 662121 & nd & nd & nd & nd \\
\hline 662122 & bdl & nd & bdl & bdl \\
\hline 662123 & bdl & bdl & bdl & bdl \\
\hline 662124 & bdl & nd & nd & bdl \\
\hline 662125 & bdl & bdl & bdl & bdl \\
\hline 662126 & bdl & bdl & bdl & bdl \\
\hline 662127 & bdl & nd & bdl & bdl \\
\hline 662128 & bdl & bdl & bdl & bdl \\
\hline 662129 & bdl & bdl & bdl & bdl \\
\hline 662130 & bdl & bdl & bdl & nd \\
\hline 662131 & bdl & nd & bdl & bdl \\
\hline 662132 & 0.76 & 0.33 & 0.35 & 0.09 \\
\hline 662133 & 2.02 & 1.83 & 0.19 & nd \\
\hline 662146 & nd & nd & nd & nd \\
\hline 662143 & nd & nd & nd & nd \\
\hline 662144 & bdl & nd & nd & bdl \\
\hline 662145 & bdl & nd & nd & bdl \\
\hline method blank & nd & nd & nd & nd \\
\hline method blank & nd & nd & nd & nd \\
\hline Maximum & 2.02 & 1.83 & 0.35 & 0.09 \\
\hline Standard deviation & 0.38 & 0.33 & 0.07 & 0.02 \\
\hline Mean & 0.10 & 0.09 & 0.02 & 0.00 \\
\hline
\end{tabular}




\section{Assessment of Groundwater, Soil-Gas, and Soil Contamination at the Vietnam Armor Training Facility}

Table 3. Mass of organic compounds detected in soil-gas samplers, Vietnam Armor Training Facility, Fort Gordon,

Georgia, July 2011.-Continued

[TPH, total petroleum hydrocarbons; $\mu \mathrm{g}$, micrograms; BTEX, summation of benzene, toluene, ethylbenzene, and total xylene; m, meta; $\mathrm{p}$, para; $\mathrm{o}$, ortho; MDL,method detection level; nd, not detected; bdl, below detection level; 662143, 662144, and 662145 are trip blanks; MTBE, methyl tert-butyl ether;

$\mathrm{C}_{11}, \mathrm{C}_{13}, \mathrm{C}_{15}$, combined masses of undecane, tridecane, and pentadecane; DCA dichloroethane; TCA, trchloroethane; TCE, trichloroethylene;

PCE, perchloroethylene; DCE, dichloroethylene; $\mathrm{CCL}_{4}$, carbon tetrachloride; DCB, dichlorobenzene]

\begin{tabular}{|c|c|c|c|c|c|c|c|}
\hline $\begin{array}{l}\text { Sampler } \\
\text { number }\end{array}$ & $\begin{array}{l}\text { Trimethyl- } \\
\text { benzenes } \\
(\mu \mathrm{g})\end{array}$ & $\begin{array}{c}\text { 1,2,4-Trimethyl- } \\
\text { benzene } \\
(\mu \mathrm{g})\end{array}$ & $\begin{array}{c}\text { 1,3,5,-Trimethyl- } \\
\text { benzene } \\
(\mu \mathrm{g})\end{array}$ & $\begin{array}{c}1,1-D C A \\
(\mu \mathrm{g})\end{array}$ & $\begin{array}{c}\text { Chloroform } \\
(\mu g)\end{array}$ & $\begin{array}{c}1,1,1-\mathrm{TCA} \\
(\mu \mathrm{g})\end{array}$ & $\begin{array}{c}\text { 1,2-DCA } \\
(\mu \mathrm{g})\end{array}$ \\
\hline MDL= & & 0.01 & 0.02 & 0.02 & 0.01 & 0.01 & 0.01 \\
\hline 662103 & nd & nd & nd & nd & nd & nd & nd \\
\hline 662104 & nd & nd & nd & nd & nd & nd & nd \\
\hline 662105 & nd & nd & nd & nd & nd & nd & nd \\
\hline 662106 & nd & nd & nd & nd & bdl & nd & nd \\
\hline 662107 & nd & nd & nd & nd & 0.02 & nd & nd \\
\hline 662108 & nd & nd & nd & nd & nd & nd & nd \\
\hline 662109 & bdl & bdl & nd & nd & nd & nd & nd \\
\hline 662110 & bdl & bdl & nd & nd & nd & nd & nd \\
\hline 662111 & nd & nd & nd & nd & nd & nd & nd \\
\hline 662112 & nd & nd & nd & nd & nd & nd & nd \\
\hline 662113 & nd & nd & nd & nd & nd & nd & nd \\
\hline 662115 & nd & nd & nd & nd & nd & nd & nd \\
\hline 662116 & nd & nd & nd & nd & nd & nd & nd \\
\hline 662117 & nd & nd & nd & nd & nd & nd & nd \\
\hline 662118 & nd & nd & nd & nd & 0.01 & nd & nd \\
\hline 662119 & nd & nd & nd & nd & nd & nd & nd \\
\hline 662120 & nd & nd & nd & nd & nd & nd & nd \\
\hline 662121 & 0.05 & 0.05 & nd & nd & nd & nd & nd \\
\hline 662122 & nd & nd & nd & nd & nd & nd & nd \\
\hline 662123 & nd & nd & nd & nd & nd & nd & nd \\
\hline 662124 & nd & nd & nd & nd & nd & nd & nd \\
\hline 662125 & nd & nd & nd & nd & nd & nd & nd \\
\hline 662126 & nd & nd & nd & nd & nd & nd & nd \\
\hline 662127 & nd & nd & nd & nd & nd & nd & nd \\
\hline 662128 & nd & nd & nd & nd & nd & nd & nd \\
\hline 662129 & nd & nd & nd & nd & nd & nd & nd \\
\hline 662130 & nd & nd & nd & nd & nd & nd & nd \\
\hline 662131 & nd & nd & nd & nd & nd & nd & nd \\
\hline 662132 & bdl & bdl & bdl & nd & nd & nd & nd \\
\hline 662133 & 0.11 & 0.07 & 0.05 & nd & bdl & nd & nd \\
\hline 662146 & bdl & bdl & nd & nd & nd & nd & nd \\
\hline
\end{tabular}


Table 3. Mass of organic compounds detected in soil-gas samplers, Vietnam Armor Training Facility, Fort Gordon, Georgia, July 2011.-Continued

[TPH, total petroleum hydrocarbons; $\mu \mathrm{g}$, micrograms; BTEX, summation of benzene, toluene, ethylbenzene, and total xylene; m, meta; $\mathrm{p}$, para; o, ortho; MDL,method detection level; nd, not detected; bdl, below detection level; 662143, 662144, and 662145 are trip blanks; MTBE, methyl tert-butyl ether; $\mathrm{C}_{11}, \mathrm{C}_{13}, \mathrm{C}_{15}$, combined masses of undecane, tridecane, and pentadecane; DCA dichloroethane; TCA, trchloroethane; TCE, trichloroethylene;

PCE, perchloroethylene; DCE, dichloroethylene; $\mathrm{CCL}_{4}$, carbon tetrachloride; $\mathrm{DCB}$, dichlorobenzene]

\begin{tabular}{|c|c|c|c|c|c|c|c|}
\hline $\begin{array}{l}\text { Sampler } \\
\text { number }\end{array}$ & $\begin{array}{l}\text { Trimethyl- } \\
\text { benzenes } \\
(\mu \mathrm{g})\end{array}$ & $\begin{array}{c}\text { 1,2,4-Trimethyl- } \\
\text { benzene } \\
(\mu \mathrm{g})\end{array}$ & $\begin{array}{c}\text { 1,3,5,-Trimethyl- } \\
\text { benzene } \\
(\mu \mathrm{g})\end{array}$ & $\begin{array}{c}1,1-D C A \\
(\mu g)\end{array}$ & $\begin{array}{c}\text { Chloroform } \\
(\mu g)\end{array}$ & $\begin{array}{c}1,1,1-\mathrm{TCA} \\
(\mu \mathrm{g})\end{array}$ & $\begin{array}{c}1,2-D C A \\
(\mu \mathrm{g})\end{array}$ \\
\hline MDL= & & 0.01 & 0.02 & 0.02 & 0.01 & 0.01 & 0.01 \\
\hline 662143 & nd & nd & nd & nd & nd & nd & nd \\
\hline 662144 & nd & nd & nd & nd & nd & nd & nd \\
\hline 662145 & nd & nd & nd & nd & nd & nd & nd \\
\hline method blank & nd & nd & nd & nd & nd & nd & nd \\
\hline method blank & nd & nd & nd & nd & nd & nd & nd \\
\hline Maximum & 0.11 & 0.07 & 0.05 & 0.00 & 0.02 & 0.00 & 0.00 \\
\hline $\begin{array}{l}\text { Standard } \\
\text { deviation }\end{array}$ & 0.02 & 0.01 & 0.01 & 0.00 & 0.00 & 0.00 & 0.00 \\
\hline Mean & 0.01 & 0.00 & 0.00 & 0.00 & 0.00 & 0.00 & 0.00 \\
\hline
\end{tabular}

Table 3. Mass of organic compounds detected in soil-gas samplers, Vietnam Armor Training Facility, Fort Gordon, Georgia, July 2011.-Continued

[TPH, total petroleum hydrocarbons; $\mu \mathrm{g}$, micrograms; BTEX, summation of benzene, toluene, ethylbenzene, and total xylene; m, meta; p, para; o, ortho; MDL,method detection level; nd, not detected; bdl, below detection level; 662143, 662144, and 662145 are trip blanks; MTBE, methyl tert-butyl ether; $\mathrm{C}_{11}, \mathrm{C}_{13}, \mathrm{C}_{15}$, combined masses of undecane, tridecane, and pentadecane; DCA dichloroethane; TCA, trchloroethane; TCE, trichloroethylene; PCE, perchloroethylene; DCE, dichloroethylene; $\mathrm{CCL}_{4}$, carbon tetrachloride; $\mathrm{DCB}$, dichlorobenzene]

\begin{tabular}{lllccc}
\hline $\begin{array}{l}\text { Sampler } \\
\text { number }\end{array}$ & TCE & PCE & C,t-1,2-DCE & t-1,2-DCE \\
$(\boldsymbol{\mu g})$ & $(\boldsymbol{\mu g})$ & $\mathbf{p g})$ & $\begin{array}{c}\text { C-1,2-DCE } \\
(\boldsymbol{\mu} \mathbf{g})\end{array}$ \\
\hline MDL= & $\mathbf{0 . 0 2}$ & $\mathbf{0 . 0 2}$ & & $\mathbf{0 . 0 5}$ & $\mathbf{0 . 0 2}$ \\
\hline 662103 & nd & nd & nd & nd & nd \\
662104 & nd & nd & nd & nd & nd \\
662105 & nd & nd & nd & nd & nd \\
662106 & nd & nd & nd & nd & nd \\
662107 & nd & nd & nd & nd & nd \\
662108 & nd & nd & nd & nd & nd \\
662109 & nd & nd & nd & nd & nd \\
662110 & nd & nd & nd & nd & nd \\
662111 & nd & nd & nd & nd & nd \\
662112 & nd & nd & nd & nd & nd \\
662113 & nd & nd & nd & nd & nd \\
662115 & nd & nd & nd & nd & nd \\
662116 & nd & nd & nd & nd & nd \\
662117 & nd & nd & nd & nd & nd \\
662118 & nd & bdl & nd & nd & nd
\end{tabular}


Table 3. Mass of organic compounds detected in soil-gas samplers, Vietnam Armor Training Facility, Fort Gordon, Georgia, July 2011._Continued

[TPH, total petroleum hydrocarbons; $\mu \mathrm{g}$, micrograms; BTEX, summation of benzene, toluene, ethylbenzene, and total xylene; m, meta; p, para; o, ortho; MDL, method detection level; nd, not detected; bdl, below detection level; 662143, 662144 , and 662145 are trip blanks; MTBE, methyl tert-butyl ether; $\mathrm{C}_{11}, \mathrm{C}_{13}, \mathrm{C}_{15}$, combined masses of undecane, tridecane, and pentadecane; DCA dichloroethane; TCA, trchloroethane; TCE, trichloroethylene; PCE, perchloroethylene; DCE, dichloroethylene; $\mathrm{CCL}_{4}$, carbon tetrachloride; $\mathrm{DCB}$, dichlorobenzene]

\begin{tabular}{|c|c|c|c|c|c|}
\hline $\begin{array}{l}\text { Sampler } \\
\text { number }\end{array}$ & $\begin{array}{l}\text { TCE } \\
(\mu g)\end{array}$ & $\begin{array}{l}\text { PCE } \\
(\mu g)\end{array}$ & $\begin{array}{c}c, t-1,2-D C E \\
(\mu \mathrm{g})\end{array}$ & $\begin{array}{c}\text { t-1,2-DCE } \\
(\mu \mathrm{g})\end{array}$ & $\begin{array}{c}\text { c-1,2-DCE } \\
(\mu \mathrm{g})\end{array}$ \\
\hline MDL= & 0.02 & 0.02 & & 0.05 & 0.02 \\
\hline 662119 & nd & nd & nd & nd & nd \\
\hline 662120 & bdl & nd & nd & nd & nd \\
\hline 662121 & nd & nd & nd & nd & nd \\
\hline 662122 & nd & nd & nd & nd & nd \\
\hline 662123 & nd & nd & nd & nd & nd \\
\hline 662124 & nd & nd & nd & nd & nd \\
\hline 662125 & nd & nd & nd & nd & nd \\
\hline 662126 & nd & nd & nd & nd & nd \\
\hline 662127 & nd & nd & nd & nd & nd \\
\hline 662128 & nd & nd & nd & nd & nd \\
\hline 662129 & nd & nd & nd & nd & nd \\
\hline 662130 & nd & nd & nd & nd & nd \\
\hline 662131 & nd & nd & nd & nd & nd \\
\hline 662132 & nd & 0.07 & nd & nd & nd \\
\hline 662133 & nd & bdl & nd & nd & nd \\
\hline 662146 & nd & nd & nd & nd & nd \\
\hline 662143 & nd & nd & nd & nd & nd \\
\hline 662144 & nd & nd & nd & nd & nd \\
\hline 662145 & nd & nd & nd & nd & nd \\
\hline method blank & nd & nd & nd & nd & nd \\
\hline method blank & nd & nd & nd & nd & nd \\
\hline Maximum & 0.00 & 0.07 & 0.00 & 0.00 & 0.00 \\
\hline $\begin{array}{l}\text { Standard } \\
\text { deviation }\end{array}$ & 0.00 & 0.01 & 0.00 & 0.00 & 0.00 \\
\hline Mean & 0.00 & 0.00 & 0.00 & 0.00 & 0.00 \\
\hline
\end{tabular}


Table 3. Mass of organic compounds detected in soil-gas samplers, Vietnam Armor Training Facility, Fort Gordon, Georgia, July 2011.-Continued

[TPH, total petroleum hydrocarbons; $\mu \mathrm{g}$, micrograms; BTEX, summation of benzene, toluene, ethylbenzene, and total xylene; m, meta; $\mathrm{p}$, para; o, ortho; MDL,method detection level; nd, not detected; bdl, below detection level; 662143, 662144, and 662145 are trip blanks; MTBE, methyl tert-butyl ether; $\mathrm{C}_{11}, \mathrm{C}_{13}, \mathrm{C}_{15}$, combined masses of undecane, tridecane, and pentadecane; DCA dichloroethane; TCA, trchloroethane; TCE, trichloroethylene; PCE, perchloroethylene; DCE, dichloroethylene; $\mathrm{CCL}_{4}$, carbon tetrachloride; $\mathrm{DCB}$, dichlorobenzene]

\begin{tabular}{|c|c|c|c|c|c|c|}
\hline $\begin{array}{l}\text { Sample } \\
\text { number }\end{array}$ & $\begin{array}{l}\mathrm{CCI}_{4} \\
(\mu \mathrm{g})\end{array}$ & $\begin{array}{c}\text { 1,4-DCB } \\
(\mu g)\end{array}$ & $\begin{array}{c}1,1,2-\mathrm{TCA} \\
(\mu \mathrm{g})\end{array}$ & $\begin{array}{c}\text { Chlorobenzene } \\
(\mu \mathrm{g})\end{array}$ & $\begin{array}{c}\text { 1,1,1,2-Tetrachloro- } \\
\text { ethane } \\
(\mu \mathrm{g})\end{array}$ & $\begin{array}{c}\text { 1,1,2,2-Tetrachlor- } \\
\text { ethane }(\mu \mathrm{g})\end{array}$ \\
\hline MDL= & 0.03 & 0.01 & 0.02 & 0.03 & 0.02 & 0.01 \\
\hline 662103 & nd & nd & nd & nd & nd & nd \\
\hline 662104 & nd & nd & nd & nd & nd & nd \\
\hline 662105 & nd & nd & nd & nd & nd & nd \\
\hline 662106 & nd & nd & nd & nd & nd & nd \\
\hline 662107 & nd & nd & nd & nd & nd & nd \\
\hline 662108 & nd & nd & nd & nd & nd & nd \\
\hline 662109 & nd & nd & nd & nd & nd & nd \\
\hline 662110 & nd & nd & nd & nd & nd & nd \\
\hline 662111 & nd & nd & nd & nd & nd & nd \\
\hline 662112 & nd & nd & nd & nd & nd & nd \\
\hline 662113 & nd & nd & nd & nd & nd & nd \\
\hline 662115 & nd & nd & nd & nd & nd & nd \\
\hline 662116 & nd & nd & nd & nd & nd & nd \\
\hline 662117 & nd & nd & nd & nd & nd & nd \\
\hline 662118 & nd & nd & nd & nd & nd & nd \\
\hline 662119 & nd & nd & nd & nd & nd & nd \\
\hline 662120 & nd & nd & bdl & nd & nd & nd \\
\hline 662121 & nd & nd & nd & nd & nd & nd \\
\hline 662122 & nd & nd & nd & nd & nd & nd \\
\hline 662123 & nd & nd & nd & nd & nd & nd \\
\hline 662124 & nd & nd & nd & nd & nd & nd \\
\hline 662125 & nd & nd & nd & nd & nd & nd \\
\hline 662126 & nd & nd & nd & nd & nd & nd \\
\hline 662127 & nd & nd & nd & nd & nd & nd \\
\hline 662128 & nd & nd & nd & nd & nd & nd \\
\hline 662129 & nd & nd & nd & nd & nd & nd \\
\hline 662130 & nd & nd & nd & nd & nd & nd \\
\hline 662131 & nd & nd & nd & nd & nd & nd \\
\hline 662132 & nd & nd & bdl & nd & nd & nd \\
\hline 662133 & nd & nd & nd & nd & nd & nd \\
\hline 662146 & nd & nd & nd & nd & nd & nd \\
\hline
\end{tabular}


Table 3. Mass of organic compounds detected in soil-gas samplers, Vietnam Armor Training Facility, Fort Gordon, Georgia, July 2011.-Continued

[TPH, total petroleum hydrocarbons; $\mu \mathrm{g}$, micrograms; BTEX, summation of benzene, toluene, ethylbenzene, and total xylene; m, meta; p, para; o, ortho; MDL, method detection level; nd, not detected; bdl, below detection level; 662143, 662144, and 662145 are trip blanks; MTBE, methyl tert-butyl ether; $\mathrm{C}_{11}, \mathrm{C}_{13}, \mathrm{C}_{15}$, combined masses of undecane, tridecane, and pentadecane; DCA dichloroethane; TCA, trchloroethane; TCE, trichloroethylene; PCE, perchloroethylene; DCE, dichloroethylene; $\mathrm{CCL}_{4}$, carbon tetrachloride; $\mathrm{DCB}$, dichlorobenzene]

\begin{tabular}{|c|c|c|c|c|c|c|}
\hline $\begin{array}{l}\text { Sample } \\
\text { number }\end{array}$ & $\begin{array}{l}\mathrm{CCI}_{4} \\
(\mu \mathrm{g})\end{array}$ & $\begin{array}{c}1,4-D C B \\
(\mu g)\end{array}$ & $\begin{array}{c}1,1,2-\text { TCA } \\
(\mu g)\end{array}$ & $\begin{array}{c}\text { Chlorobenzene } \\
(\mu \mathrm{g})\end{array}$ & $\begin{array}{c}\text { 1,1,1,2-Tetrachloro- } \\
\text { ethane } \\
(\mu \mathrm{g})\end{array}$ & $\begin{array}{c}\text { 1,1,2,2-Tetrachlor- } \\
\text { ethane ( } \mu \mathrm{g})\end{array}$ \\
\hline MDL= & 0.03 & 0.01 & 0.02 & 0.03 & 0.02 & 0.01 \\
\hline 662143 & nd & nd & nd & nd & nd & nd \\
\hline 662144 & nd & nd & nd & nd & nd & nd \\
\hline 662145 & nd & nd & nd & nd & nd & nd \\
\hline method blank & nd & nd & nd & nd & nd & nd \\
\hline method blank & nd & nd & nd & nd & nd & nd \\
\hline Maximum & 0.00 & 0.00 & 0.01 & 0.00 & 0.00 & 0.00 \\
\hline $\begin{array}{l}\text { Standard } \\
\text { deviation }\end{array}$ & 0.00 & 0.00 & 0.00 & 0.00 & 0.00 & 0.00 \\
\hline Mean & 0.00 & 0.00 & 0.00 & 0.00 & 0.00 & 0.00 \\
\hline
\end{tabular}


Table 3. Mass of organic compounds detected in soil-gas samplers, Vietnam Armor Training Facility, Fort Gordon, Georgia, July 2011.-Continued

[TPH, total petroleum hydrocarbons; $\mu \mathrm{g}$, micrograms; BTEX, summation of benzene, toluene, ethylbenzene, and total xylene; m, meta; p, para; o, ortho; MDL, method detection level; nd, not detected; bdl, below detection level; 662143, 662144, and 662145 are trip blanks; MTBE, methyl tert-butyl ether; $\mathrm{C}_{11}, \mathrm{C}_{13}, \mathrm{C}_{15}$, combined masses of undecane, tridecane, and pentadecane;

DCA dichloroethane; TCA, trchloroethane; TCE, trichloroethylene; PCE, perchloroethylene; DCE, dichloroethylene; $\mathrm{CCL}_{4}$, carbon tetrachloride; $\mathrm{DCB}$, dichlorobenzene]

\begin{tabular}{|c|c|c|}
\hline $\begin{array}{l}\text { Sampler } \\
\text { number }\end{array}$ & 1,3-Dichlorobenzene ( $\mu \mathrm{g})$ & 1,2-Dichlorobenzene $(\mu \mathrm{g})$ \\
\hline 662103 & nd & nd \\
\hline 662104 & nd & nd \\
\hline 662105 & nd & nd \\
\hline 662106 & nd & nd \\
\hline 662107 & nd & nd \\
\hline 662108 & nd & nd \\
\hline 662109 & nd & nd \\
\hline 662110 & nd & nd \\
\hline 662111 & nd & nd \\
\hline 662112 & nd & nd \\
\hline 662113 & nd & nd \\
\hline 662115 & nd & nd \\
\hline 662116 & nd & nd \\
\hline 662117 & nd & nd \\
\hline 662118 & nd & nd \\
\hline 662119 & nd & nd \\
\hline 662120 & nd & nd \\
\hline 662121 & nd & nd \\
\hline 662122 & nd & nd \\
\hline 662123 & nd & nd \\
\hline 662124 & nd & nd \\
\hline 662125 & nd & nd \\
\hline 662126 & nd & nd \\
\hline 662127 & nd & nd \\
\hline 662128 & nd & nd \\
\hline 662129 & nd & nd \\
\hline 662130 & nd & nd \\
\hline 662131 & nd & nd \\
\hline 662132 & nd & nd \\
\hline 662133 & nd & nd \\
\hline 662146 & nd & nd \\
\hline
\end{tabular}


Table 3. Mass of organic compounds detected in soil-gas samplers, Vietnam Armor Training Facility, Fort Gordon, Georgia, July 2011.-Continued

[TPH, total petroleum hydrocarbons; $\mu \mathrm{g}$, micrograms; BTEX, summation of benzene, toluene, ethylbenzene, and total xylene; m, meta; , para; o, ortho; MDL, method detection level; nd, not detected; bdl, below detection level; 662143, 662144, and 662145 are trip blanks; MTBE, methyl tert-butyl ether; $\mathrm{C}_{11}, \mathrm{C}_{13}, \mathrm{C}_{15}$, combined masses of undecane, tridecane, and pentadecane; DCA dichloroethane; TCA, trchloroethane; TCE, trichloroethylene; PCE, perchloroethylene; DCE, dichloroethylene; $\mathrm{CCL}_{4}$, carbon tetrachloride; DCB, dichlorobenzene]

\begin{tabular}{lcc}
\hline $\begin{array}{l}\text { Sampler } \\
\text { number }\end{array}$ & 1,3-Dichlorobenzene $(\boldsymbol{\mu g})$ & 1,2-Dichlorobenzene $(\boldsymbol{\mu g})$ \\
\hline 662143 & nd & nd \\
662144 & nd & nd \\
662145 & nd & nd \\
& & \\
method blank & nd & nd \\
method blank & nd & nd \\
& & \\
Maximum & 0.00 & 0.00 \\
Standard deviation & 0.00 & 0.00 \\
Mean & 0.00 & 0.00 \\
\hline
\end{tabular}


Table 4. Mass of explosives and chemical agents detected in soil-gas samplers collected from the Vietnam Area Training Facility, Fort Gordon, Georgia, 2009-2010.

[ $\mu \mathrm{g}$, microgram; MDL, method detection level; nd, not detected; bdl, below detection level; 644252, 644253, 644254, 644255, and 644256 are trip blanks; bdl, below detection level]

\begin{tabular}{lcccc}
\hline $\begin{array}{l}\text { Sampler } \\
\text { number }\end{array}$ & $\begin{array}{c}\text { Dimethyl } \\
\text { disulfide } \\
(\boldsymbol{\mu g})\end{array}$ & $\begin{array}{c}\text { Dimethyl methyl } \\
\text { phosphonate } \\
(\boldsymbol{\mu g})\end{array}$ & $\begin{array}{c}\text { 1,4-Thioxane } \\
(\boldsymbol{\mu g})\end{array}$ & $\begin{array}{c}\text { Nitrobenzene } \\
(\boldsymbol{\mu g})\end{array}$ \\
\hline MDL & $\mathbf{0 . 1 0}$ & $\mathbf{0 . 1 0}$ & $\mathbf{0 . 1 0}$ & $\mathbf{0 . 1 0}$ \\
644205 & nd & nd & nd & nd \\
644207 & nd & nd & nd & nd \\
644208 & nd & nd & nd & nd \\
644209 & nd & nd & nd & nd \\
& & & nd & nd \\
644252 & nd & nd & nd & nd \\
644253 & nd & nd & nd & nd \\
644254 & nd & nd & nd & nd \\
644255 & nd & nd & nd & nd
\end{tabular}

Table 4. Mass of explosives and chemical agents detected in soil-gas samplers collected from the Vietnam Area Training Facility, Fort Gordon, Georgia, 2009-2010.-Continued

\begin{tabular}{|c|c|c|c|c|c|}
\hline $\begin{array}{l}\text { Sampler } \\
\text { number }\end{array}$ & $\begin{array}{c}\text { Diisopropyl } \\
\text { methylphosphonate } \\
(\mu \mathrm{g})\end{array}$ & $\begin{array}{c}\text { 1,4-Dithiane } \\
(\mu \mathrm{g})\end{array}$ & $\begin{array}{c}\text { 2-Nitrotoluene } \\
(\mu \mathrm{g})\end{array}$ & $\begin{array}{c}\text { 3-Nitrotoluene } \\
(\mu \mathrm{g})\end{array}$ & $\begin{array}{c}\text { 4-Nitrotoluene } \\
(\mu \mathrm{g})\end{array}$ \\
\hline MDL & 0.10 & 0.10 & 0.10 & 0.10 & 0.10 \\
\hline 644205 & nd & nd & nd & nd & nd \\
\hline 644207 & nd & nd & nd & nd & nd \\
\hline 644208 & nd & nd & nd & nd & nd \\
\hline 644209 & nd & nd & nd & nd & nd \\
\hline 644252 & nd & nd & nd & nd & nd \\
\hline 644253 & nd & nd & nd & nd & nd \\
\hline 644254 & nd & nd & nd & nd & nd \\
\hline 644255 & nd & nd & nd & nd & nd \\
\hline 644256 & nd & nd & nd & nd & nd \\
\hline
\end{tabular}


Table 4. Mass of explosives and chemical agents detected in soil-gas samplers collected from the Vietnam Area Training Facility, Fort Gordon, Georgia, 2009-2010._Continued

\begin{tabular}{|c|c|c|c|c|}
\hline $\begin{array}{l}\text { Sampler } \\
\text { number }\end{array}$ & $\begin{array}{c}\text { Thiodiglycol } \\
\text { ( } \mu \mathrm{g})\end{array}$ & $\begin{array}{c}\text { Benzothiazole } \\
(\mu \mathrm{g})\end{array}$ & $\begin{array}{c}\text { Chloroacetophenones } \\
(\mu \mathrm{g})\end{array}$ & $\begin{array}{c}\text { p-Chlorophenyl } \\
\text { methyl sulfide } \\
(\mu \mathrm{g})\end{array}$ \\
\hline MDL & 0.20 & 0.10 & 0.10 & 0.10 \\
\hline 644205 & nd & bdl & nd & nd \\
\hline 644207 & nd & bdl & nd & nd \\
\hline 644208 & nd & bdl & nd & nd \\
\hline 644209 & nd & bdl & nd & nd \\
\hline 644252 & nd & nd & nd & nd \\
\hline 644253 & nd & nd & nd & nd \\
\hline 644254 & nd & nd & nd & nd \\
\hline 644255 & nd & nd & nd & nd \\
\hline 644256 & nd & nd & nd & nd \\
\hline
\end{tabular}

Table 4. Mass of explosives and chemical agents detected in soil-gas samplers collected from the Vietnam Area Training Facility, Fort Gordon, Georgia, 2009-2010.-Continued

\begin{tabular}{|c|c|c|c|c|}
\hline $\begin{array}{l}\text { Sampler } \\
\text { number }\end{array}$ & $\begin{array}{c}\text { 1,3-Dinitrobenzene } \\
(\mu \mathrm{g})\end{array}$ & $\begin{array}{c}\text { 2,6-Dinitrotoluene } \\
(\mu \mathrm{g})\end{array}$ & $\begin{array}{c}\text { 2,4-Dinitrotoluene } \\
(\mu \mathrm{g})\end{array}$ & $\begin{array}{c}\text { 1,3,5-Trinitrobenzene } \\
(\mu \mathrm{g})\end{array}$ \\
\hline MDL & 0.10 & 0.10 & 0.10 & 0.10 \\
\hline 644205 & nd & nd & nd & nd \\
\hline 644207 & nd & nd & nd & nd \\
\hline 644208 & nd & nd & nd & nd \\
\hline 644209 & nd & nd & nd & nd \\
\hline 644252 & nd & nd & nd & nd \\
\hline 644253 & nd & nd & nd & nd \\
\hline 644254 & nd & nd & nd & nd \\
\hline 644255 & nd & nd & nd & nd \\
\hline 644256 & nd & nd & bdl & nd \\
\hline
\end{tabular}


Table 4. Mass of explosives and chemical agents detected in soil-gas samplers collected from the Vietnam Area Training Facility, Fort Gordon, Georgia, 20092010.-Continued

\begin{tabular}{lccc}
\hline $\begin{array}{l}\text { Sampler } \\
\text { number }\end{array}$ & $\begin{array}{c}\text { p-Chlorophenyl } \\
\text { methyl sulfoxide } \\
(\boldsymbol{\mu g})\end{array}$ & $\begin{array}{c}\text { p-Chlorophenyl } \\
\text { methyl sulfone } \\
(\boldsymbol{\mu g})\end{array}$ & $\begin{array}{c}\mathbf{2 , 4 , 6} \text {-Trinitrotoluene } \\
(\boldsymbol{\mu} \mathbf{g})\end{array}$ \\
\hline MDL & $\mathbf{0 . 1 0}$ & $\mathbf{0 . 1 0}$ & $\mathbf{0 . 1 0}$ \\
644205 & bdl & bdl & nd \\
644207 & bdl & bdl & nd \\
644208 & bdl & bdl & nd \\
644209 & bdl & bdl & nd \\
& & & nd \\
644252 & nd & bdl & nd \\
644253 & nd & bdl & nd \\
644254 & nd & bdl & nd \\
644255 & nd & bdl & nd \\
644256 & nd & bdl & \\
\hline
\end{tabular}


Table 5. Inorganic compounds detected in the soil from land surface to 6 inches below land surface, site 1, Vietnam Armor Training Facility, Fort Gordon, Georgia, August 30, 2010.

$[\mu \mathrm{g} / \mathrm{g}$, microgram per gram; USEPA RSL, U.S. Environmental Protection Agency Regional Screening Level, Industrial Soil; mg/kg, milligram per kilogram; SCDHEC, South Carolina Department of Health and Environmental Control; -, not applicable; *, Resource Conservation and Recovery Act (RCRA) metal; yellow highlight indicates exceedance; nr, not reported. Note: $1 \mu \mathrm{g} / \mathrm{g}$ is equivalent to $1 \mathrm{mg} / \mathrm{kg}$, and $1 \mathrm{mg} / \mathrm{kg}$ is equivalent to 1 part per million (ppm); selenium and mercury were not analyzed]

\begin{tabular}{|c|c|c|c|}
\hline Compound & $\begin{array}{l}\text { Result } \\
(\mu \mathrm{g} / \mathrm{g})\end{array}$ & $\begin{array}{c}\text { USEPA } \\
\text { RSL } \\
\text { (mg/kg) }\end{array}$ & $\begin{array}{c}\text { SCDHEC } \\
\text { background } \\
\text { (mg/kg) }\end{array}$ \\
\hline Aluminum & 15,500 & 990,000 & 13,528 \\
\hline Antimony & 0.31 & 410 & - \\
\hline Arsenic* & 2.5 & 260 & 6.1 \\
\hline Barium* & 70.9 & 190,000 & 38 \\
\hline Beryllium & 0.31 & 2,000 & 0.6 \\
\hline Bismuth & $\mathrm{nr}$ & - & - \\
\hline Cadmium* & 0.04 & 800 & 1 \\
\hline Calcium & 248 & - & 699 \\
\hline Cerium & 141 & - & - \\
\hline Cesium & 2.3 & - & - \\
\hline Chromium* & 26.1 & $1,500,000$ & 16 \\
\hline Cobalt & 1.6 & 300 & 4 \\
\hline Copper & 7.4 & 41,000 & 9 \\
\hline Gallium & 5.9 & - & - \\
\hline Iron & 6,850 & 720,000 & 15,608 \\
\hline Lanthanum & 37.1 & - & - \\
\hline Lead* & 12.5 & 800 & 16 \\
\hline Lithium & 6.8 & 2,000 & - \\
\hline Magnesium & 331 & - & 988 \\
\hline Manganese & 174 & 23,000 & 120 \\
\hline Molybdenum & 0.47 & 5,100 & - \\
\hline Nickel & 5.9 & 47,000 & 6 \\
\hline Niobium & 6.7 & - & - \\
\hline Phosphorus & 198 & - & - \\
\hline Potassium & 838 & - & 856 \\
\hline Rubidium & 10.9 & - & - \\
\hline Scandium & 3 & - & - \\
\hline Silver* & 0.025 & 5,100 & 4 \\
\hline Sodium & 107 & - & 194 \\
\hline Strontium & 12.5 & 610,000 & - \\
\hline Thallium & 0.12 & - & 4.5 \\
\hline Thorium & 4.56 & - & - \\
\hline Titanium & $\mathrm{nr}$ & - & - \\
\hline Uranium & 1.29 & - & - \\
\hline Vanadium & 24.6 & 5,200 & - \\
\hline Yttrium & 27.1 & - & - \\
\hline Zinc & 13.9 & 310,000 & 23 \\
\hline
\end{tabular}


Table 6. Inorganic compounds detected in the soil from land surface to 6 inches below land surface, site 2, Vietnam Armor Training Facility, Fort Gordon, Georgia, August 30, 2010.

$[\mu \mathrm{g} / \mathrm{g}$, microgram per gram; USEPA RSL, U.S. Environmental Protection Agency Regional Screening Level, Industrial Soil; mg/kg, milligram per kilogram; SCDHEC, South Carolina Department of Health and Environmental Control; yellow highlight indicates exceedence; -, not applicable; *, Resource Conservation and Recovery Act (RCRA) metal; nr, not reported. Note: $1 \mu \mathrm{g} / \mathrm{g}$ is equivalent to $1 \mathrm{mg} / \mathrm{kg}$, and $1 \mathrm{mg} / \mathrm{kg}$ is equivalent to 1 part per million (ppm); selenium and mercury were not analyzed]

\begin{tabular}{|c|c|c|c|}
\hline Compound & $\begin{array}{l}\text { Result } \\
(\mu \mathrm{g} / \mathrm{g})\end{array}$ & $\begin{array}{c}\text { USEPA } \\
\text { RSL } \\
\text { (mg/kg) }\end{array}$ & $\begin{array}{c}\text { SCDHEC } \\
\text { background } \\
\text { (mg/kg) }\end{array}$ \\
\hline Aluminum & 24,800 & 990,000 & 13,528 \\
\hline Antimony & 0.74 & 410 & - \\
\hline Arsenic* & 4.7 & 260 & 6.1 \\
\hline Barium* & 106 & 190,000 & 38 \\
\hline Beryllium & 0.5 & 2,000 & 0.6 \\
\hline Bismuth & $\mathrm{nr}$ & - & - \\
\hline Cadmium* & 0.09 & 800 & 1 \\
\hline Calcium & 404 & - & 699 \\
\hline Cerium & 186 & - & - \\
\hline Cesium & 2.9 & - & - \\
\hline Chromium* & 46.8 & $1,500,000$ & 16 \\
\hline Cobalt & 2.1 & 300 & 4 \\
\hline Copper & 10.6 & 41,000 & 9 \\
\hline Gallium & 9.1 & - & - \\
\hline Iron & 13,900 & 720,000 & 15,608 \\
\hline Lanthanum & 46.5 & - & - \\
\hline Lead* & 18 & 800 & 16 \\
\hline Lithium & 10.5 & 2,000 & - \\
\hline Magnesium & 475 & - & 988 \\
\hline Manganese & 208 & 23,000 & 120 \\
\hline Molybdenum & 0.94 & 5,100 & - \\
\hline Nickel & 8.5 & 47,000 & 6 \\
\hline Niobium & 8.7 & - & - \\
\hline Phosphorus & 240 & - & - \\
\hline Potassium & 1,200 & - & 856 \\
\hline Rubidium & 13.9 & - & - \\
\hline Scandium & 4.9 & - & - \\
\hline Silver* & 0.035 & 5,100 & 4 \\
\hline Sodium & 164 & - & 194 \\
\hline Strontium & 23.4 & 610,000 & - \\
\hline Thallium & 0.17 & - & 4.5 \\
\hline Thorium & 6.47 & - & - \\
\hline Titanium & $\mathrm{nr}$ & - & - \\
\hline Uranium & 1.68 & - & - \\
\hline Vanadium & 48.9 & 5,200 & - \\
\hline Yttrium & 26.1 & - & - \\
\hline Zinc & 30 & 310,000 & 23 \\
\hline
\end{tabular}


Table 7. Inorganic compounds detected in the soil from land surface to 6 inches below land surface, site 3, Vietnam Armor Training Facility, Fort Gordon, Georgia, August 30, 2010.

$[\mu \mathrm{g} / \mathrm{g}$, microgram per gram; USEPA RSL, U.S. Environmental Protection Agency Regional Screening Level, Industrial Soil; mg/kg, milligram per kilogram; SCDHEC, South Carolina Department of Health and Environmental Control; yellow highlight indicates exceedance; -, not applicable; *, Resource Conservation and Recovery Act (RCRA) metal; nr, not reported. Note: $1 \mu \mathrm{g} / \mathrm{g}$ is equivalent to $1 \mathrm{mg} / \mathrm{kg}$, and $1 \mathrm{mg} / \mathrm{kg}$ is equivalent to 1 part per million (ppm); selenium and mercury were not analyzed]

\begin{tabular}{|c|c|c|c|}
\hline Compound & $\begin{array}{l}\text { Result } \\
(\mu \mathrm{g} / \mathrm{g})\end{array}$ & $\begin{array}{c}\text { USEPA } \\
\text { RSL } \\
\text { (mg/kg) }\end{array}$ & $\begin{array}{c}\text { SCDHEC } \\
\text { background } \\
\text { (mg/kg) }\end{array}$ \\
\hline Aluminum & 48,400 & 990,000 & 13,528 \\
\hline Antimony & 1.1 & 410 & - \\
\hline Arsenic* & 6.8 & 260 & 6.1 \\
\hline Barium* & 130 & 190,000 & 38 \\
\hline Beryllium & 0.69 & 2,000 & 0.6 \\
\hline Bismuth & $\mathrm{nr}$ & - & - \\
\hline Cadmium* & 0.2 & 800 & 1 \\
\hline Calcium & 1,690 & - & 699 \\
\hline Cerium & 137 & - & - \\
\hline Cesium & 2.8 & - & - \\
\hline Chromium* & 62.6 & $1,500,000$ & 16 \\
\hline Cobalt & 2.9 & 300 & 4 \\
\hline Copper & 21.8 & 41,000 & 9 \\
\hline Gallium & 13.5 & - & - \\
\hline Iron & 22,100 & 720,000 & 15,608 \\
\hline Lanthanum & 39.7 & - & - \\
\hline Lead* & 117 & 800 & 16 \\
\hline Lithium & 14.1 & 2,000 & - \\
\hline Magnesium & 777 & - & 988 \\
\hline Manganese & 120 & 23,000 & 120 \\
\hline Molybdenum & 1.2 & 5,100 & - \\
\hline Nickel & 16.5 & 47,000 & 6 \\
\hline Niobium & 10 & - & - \\
\hline Phosphorus & 309 & - & - \\
\hline Potassium & 2,100 & - & 856 \\
\hline Rubidium & 17.2 & - & - \\
\hline Scandium & 6.9 & - & - \\
\hline Silver* & 0.061 & 5,100 & 4 \\
\hline Sodium & 1,010 & - & 194 \\
\hline Strontium & 36.8 & 610,000 & - \\
\hline Thallium & 0.18 & - & 4.5 \\
\hline Thorium & 8.35 & - & - \\
\hline Titanium & $\mathrm{nr}$ & - & - \\
\hline Uranium & 1.86 & - & - \\
\hline Vanadium & 66.4 & 5,200 & - \\
\hline Yttrium & 16.4 & - & - \\
\hline Zinc & 83.9 & 310,000 & 23 \\
\hline
\end{tabular}


Table 8. Inorganic compounds detected in the soil from land surface to 6 inches below land surface, site 4, Vietnam Armor Training Facility, Fort Gordon, Georgia, August 30, 2010.

[ $\mu \mathrm{g} / \mathrm{g}$, microgram per gram; USEPA RSL, U.S. Environmental Protection Agency Regional Screening Level, Industrial Soil; mg/kg, milligram per kilogram; SCDHEC, South Carolina Department of Health and Environmental Control; -, not applicable; *, Resource Conservation and Recovery Act (RCRA) metal; yellow highlight indicates exceedence; nr, not reported. Note: $1 \mu \mathrm{g} / \mathrm{g}$ is equivalent to $1 \mathrm{mg} / \mathrm{kg}$, and $1 \mathrm{mg} / \mathrm{kg}$ is equivalent to 1 part per million (ppm); selenium and mercury were not analyzed]

\begin{tabular}{|c|c|c|c|}
\hline Compound & $\begin{array}{l}\text { Result } \\
(\mu \mathrm{g} / \mathrm{g})\end{array}$ & $\begin{array}{c}\text { USEPA } \\
\text { RSL } \\
\text { (mg/kg) }\end{array}$ & $\begin{array}{c}\text { SCDHEC } \\
\text { background } \\
\text { (mg/kg) }\end{array}$ \\
\hline Aluminum & 27,700 & 990,000 & 13,528 \\
\hline Antimony & 0.6 & 410 & - \\
\hline Arsenic* & 6.6 & 260 & 6.1 \\
\hline Barium* & 101 & 190,000 & 38 \\
\hline Beryllium & 0.47 & 2,000 & 0.6 \\
\hline Bismuth & $\mathrm{nr}$ & - & - \\
\hline Cadmium* & 0.05 & 800 & 1 \\
\hline Calcium & 721 & - & 699 \\
\hline Cerium & 154 & - & - \\
\hline Cesium & 2.5 & - & - \\
\hline Chromium* & 63.3 & $1,500,000$ & 16 \\
\hline Cobalt & 2 & 300 & 4 \\
\hline Copper & 10.3 & 41,000 & 9 \\
\hline Gallium & 9 & - & - \\
\hline Iron & 16,900 & 720,000 & 15,608 \\
\hline Lanthanum & 41.6 & - & - \\
\hline Lead* & 26.5 & 800 & 16 \\
\hline Lithium & 10.6 & 2,000 & - \\
\hline Magnesium & 510 & - & 988 \\
\hline Manganese & 189 & 23,000 & 120 \\
\hline Molybdenum & 0.85 & 5,100 & - \\
\hline Nickel & 9.8 & 47,000 & 6 \\
\hline Niobium & 7.1 & - & - \\
\hline Phosphorus & 254 & - & - \\
\hline Potassium & 960 & - & 856 \\
\hline Rubidium & 11.4 & - & - \\
\hline Scandium & 4.6 & - & - \\
\hline Silver* & 0.038 & 5,100 & 4 \\
\hline Sodium & 135 & - & 194 \\
\hline Strontium & 26.9 & 610,000 & - \\
\hline Thallium & 0.14 & - & 4.5 \\
\hline Thorium & 7.6 & - & - \\
\hline Titanium & $\mathrm{nr}$ & - & - \\
\hline Uranium & 1.44 & - & - \\
\hline Vanadium & 51.9 & 5,200 & - \\
\hline Yttrium & 19.6 & - & - \\
\hline Zinc & 33.2 & 310,000 & 23 \\
\hline
\end{tabular}


Table 9. Inorganic compounds detected in the soil from land surface to 6 inches below land surface, site 5, Vietnam Armor Training Facility, Fort Gordon, Georgia, August 30, 2010.

$[\mu \mathrm{g} / \mathrm{g}$, microgram per gram; USEPA RSL, U.S. Environmental Protection Agency Regional Screening Level, Industrial Soil; mg/kg, milligram per kilogram; SCDHEC, South Carolina Department of Health and Environmental Control; yellow highlight indicates exceedence; -, not applicable; *, Resource Conservation and Recovery Act (RCRA) metal; nr, not reported. Note: $1 \mu \mathrm{g} / \mathrm{g}$ is equivalent to $1 \mathrm{mg} / \mathrm{kg}$, and $1 \mathrm{mg} / \mathrm{kg}$ is equivalent to 1 part per million (ppm); selenium and mercury were not analyzed]

\begin{tabular}{|c|c|c|c|}
\hline Compound & $\begin{array}{l}\text { Result } \\
(\mu \mathrm{g} / \mathrm{g})\end{array}$ & $\begin{array}{c}\text { USEPA } \\
\text { RSL } \\
\text { (mg/kg) }\end{array}$ & $\begin{array}{c}\text { SCDHEC } \\
\text { background } \\
\text { (mg/kg) }\end{array}$ \\
\hline Aluminum & 28,300 & 990,000 & 13,528 \\
\hline Antimony & 0.65 & 410 & - \\
\hline Arsenic* & 6.2 & 260 & 6.1 \\
\hline Barium* & 90.1 & 190,000 & 38 \\
\hline Beryllium & 0.57 & 2,000 & 0.6 \\
\hline Bismuth & $\mathrm{nr}$ & - & - \\
\hline Cadmium* & 0.23 & 800 & 1 \\
\hline Calcium & 2,130 & - & 699 \\
\hline Cerium & 79.1 & - & - \\
\hline Cesium & 2.2 & - & - \\
\hline Chromium* & 35.7 & $1,500,000$ & 16 \\
\hline Cobalt & 2.7 & 300 & 4 \\
\hline Copper & 16.8 & 41,000 & 9 \\
\hline Gallium & 8.7 & - & - \\
\hline Iron & 15,600 & 720,000 & 15,608 \\
\hline Lanthanum & 26.2 & - & - \\
\hline Lead* & 44.7 & 800 & 16 \\
\hline Lithium & 11.6 & 2,000 & - \\
\hline Magnesium & 1,510 & - & 988 \\
\hline Manganese & 149 & 23,000 & 120 \\
\hline Molybdenum & 0.72 & 5,100 & - \\
\hline Nickel & 11.7 & 47,000 & 6 \\
\hline Niobium & 7.8 & - & - \\
\hline Phosphorus & 326 & - & - \\
\hline Potassium & 2,240 & - & 856 \\
\hline Rubidium & 16 & - & - \\
\hline Scandium & 4.5 & - & - \\
\hline Silver* & 0.089 & 5,100 & 4 \\
\hline Sodium & 1,950 & - & 194 \\
\hline Strontium & 45.3 & 610,000 & - \\
\hline Thallium & 0.14 & - & 4.5 \\
\hline Thorium & 4.95 & - & - \\
\hline Titanium & $\mathrm{nr}$ & - & - \\
\hline Uranium & 1.39 & - & - \\
\hline Vanadium & 42.6 & 5,200 & - \\
\hline Yttrium & 13.5 & - & - \\
\hline Zinc & 109 & 310,000 & 23 \\
\hline
\end{tabular}


Prepared by:

USGS Publishing Network

Raleigh Publishing Service Center

3916 Sunset Ridge Road

Raleigh, NC 27607

For additional information regarding this publication, contact: USGS South Carolina Water Science Center

Stephenson Center, Suite 129

720 Gracern Road

Columbia, SC 29210-7651

Or visit the USGS South Carolina Water Science Center Web site at: http://sc.water.usgs.gov 


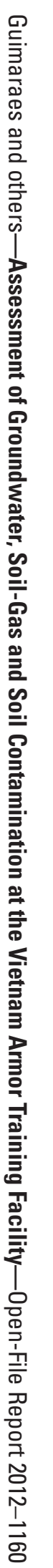

